\title{
Evaluation of Physical-Chemical and Biological Treatment of Shale Oil Retort Water
}

B. W. Mercer

M. J. Mason

R. R. Spencer

A. L. Wong

W. Wakamiya

September 1982

Prepared for the U.S. Department of Energy under Contract DE-AC06-76RLO 1830

Pacific Northwest Laboratory Operated for the U.S. Department of Energy by Battelle Memorial Institute 


\title{
DISCLAIMER
}

This report was prepared as an account of work sponsored by an agency of the United States Government. Neither the United States Government nor any agency thereof, nor any of their employees, makes any warranty, express or implied. or assumes any legal liability or responsibility for the accuracy, completeness, or usefulness of any information, apparatus, product, or process disclosed, or represents that its use would not infringe privately owned rights. Reference herein to any specific commercial product, process, or service by trade name, trademark, manufacturer, or otherwise, does not necessarily constitute or imply its endorsement, recommeidation, or favoring by the United States Government or any agency thereof. The views and opinions of authors expressed herein do not necessarily state or reflect those of the United States Government or any agency thereof.

\author{
PACIFIC NORTHWEST I.ABORATORY \\ operated by \\ BATTELLE \\ for the \\ UNITED STATES DEPARTMENT OF ENERGY \\ under Contract DE-AC06-76RLO 1830
}

\begin{tabular}{|c|c|}
\hline \multicolumn{2}{|c|}{$\begin{array}{c}\text { National Technical Information Service } \\
\text { United States Department of Commerce } \\
5285 \text { Port Roval Road } \\
\text { Springfield, Virginia } 22151\end{array}$} \\
\hline \multicolumn{2}{|c|}{$\begin{array}{l}\text { NTIS Price Codes } \\
\text { Microfiche A01 }\end{array}$} \\
\hline \multicolumn{2}{|c|}{ Printed Copy } \\
\hline Pages & $\begin{array}{l}\text { Price } \\
\text { Codes }\end{array}$ \\
\hline $001-025$ & $\mathrm{~A} 02$ \\
\hline $026-050$ & $\mathrm{~A} 03$ \\
\hline $051-075$ & $\mathrm{~A} 04$ \\
\hline $076-100$ & A05 \\
\hline $10:-125$ & $A 06$ \\
\hline $126-150$ & $A 07$ \\
\hline $151-175$ & $A 08$ \\
\hline $176-200$ & A09 \\
\hline $201-225$ & $A 010$ \\
\hline $226-250$ & A011 \\
\hline $251-275$ & A012 \\
\hline $276-300$ & \\
\hline
\end{tabular}


EVALUATION OF PHYSICAL-CHEMICAL AND BIOLOGICAL TREATMENT OF SHALE OIL RETORT WATER

B. W. Mercer

M. J. Mason

R. R. Spencer

A. L. Wong

W. Wakamiya

September 1982

Prepared for the U.S. Department of Energy under Contract DE-AC06-76RLO 1830

Pac if ic Northwest Laboratory Richland, Washington 99352 
, 


\section{ACKNOWLEDGMENTS}

The authors wish to express their gratitude to M. A. Lekas of Geokinetics, Inc., and R. N. Heistand of Paraho Development Corporation who supplied samples of retort water for these studies. 
, 


\section{CONTENTS}

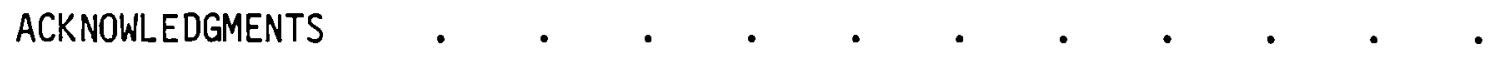

i i

INTRODUCTION

SUMMARY AND CONCLUSIONS

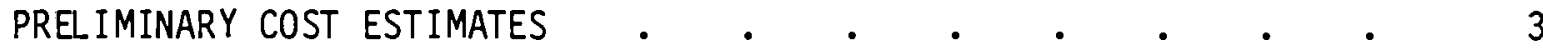

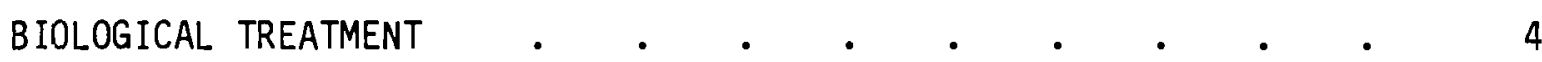

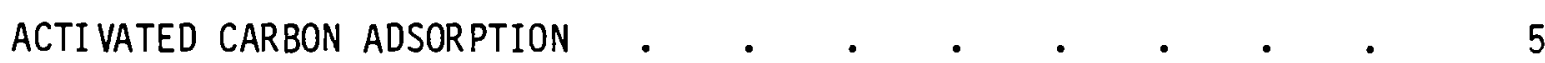

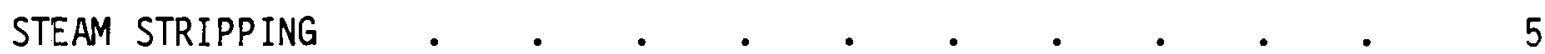

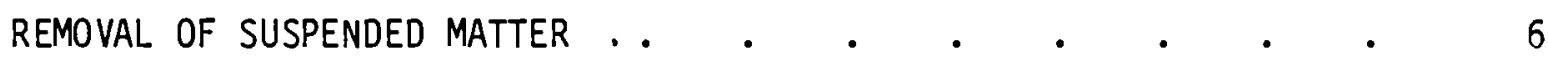

HEAVY METALS SCAVENGING

RECOMMENDED FUTURE RESEARCH $\quad$ • $\quad$ •

RETORT WATER QUALITY AND DISCHARGE/REUSE

REQUIREMENTS

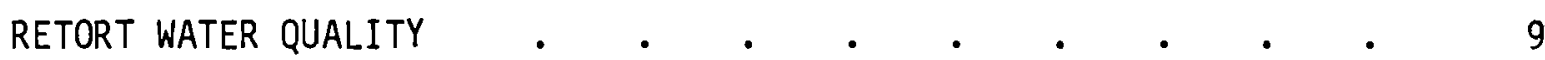

Simulated In Situ Retort Water . . . . . . . 9

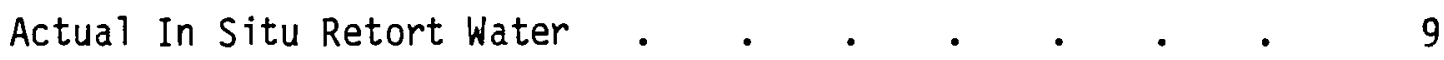

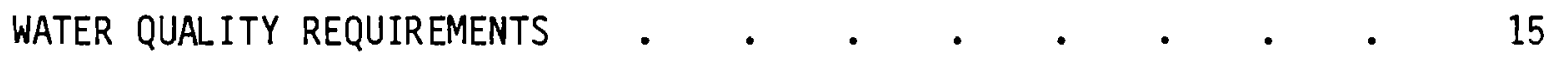

Discharge Limitations $\quad . \quad$. $\quad . \quad$. $\quad . \quad$. 15

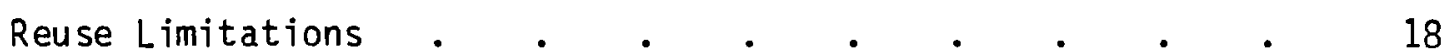

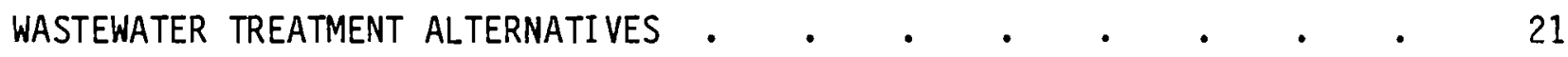

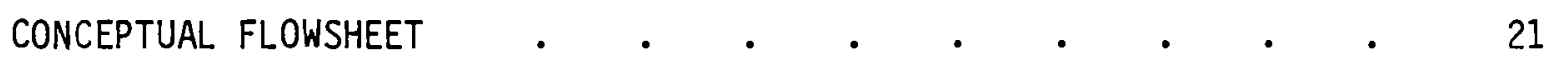

REMOVAL OF RESIDUAL SUSPENDED OILS AND SOLIDS $\quad$ • $\quad$ • $\quad$ • 22

Gravity Separation . . . . . . . . . . 23

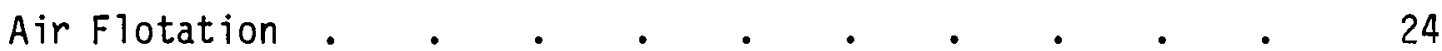

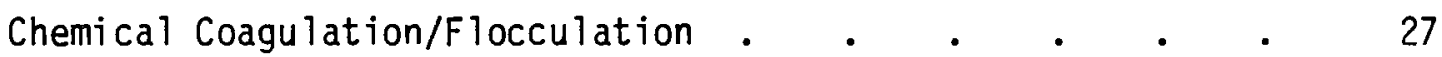

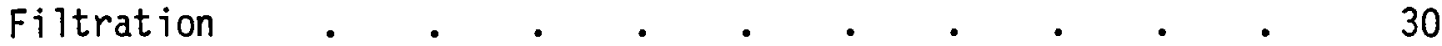




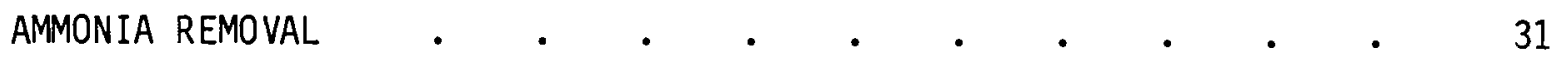

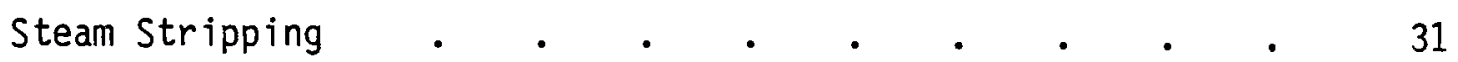

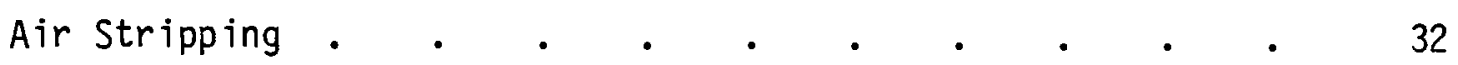

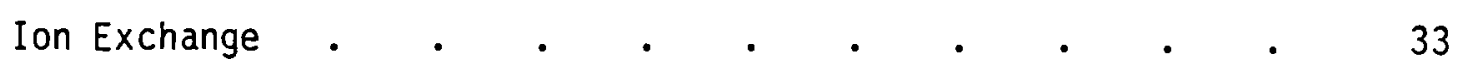

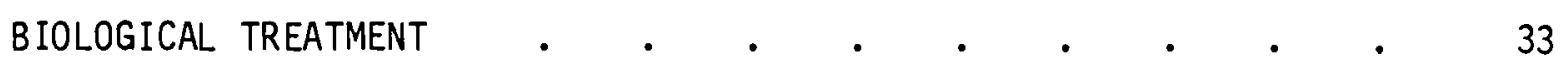

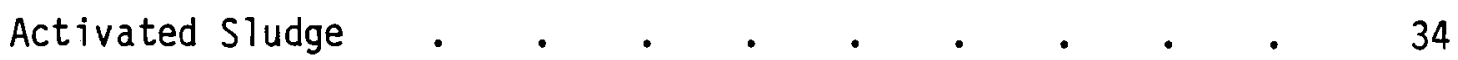

Trickling Filters .

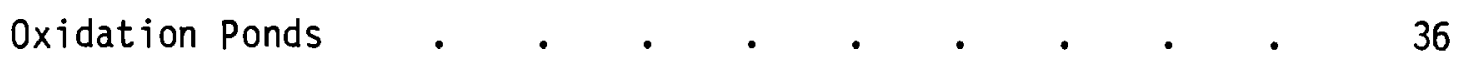

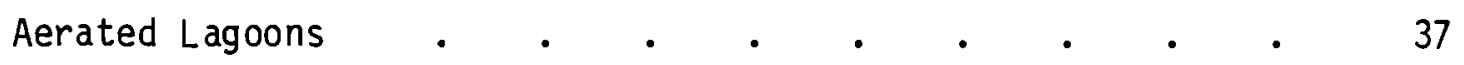

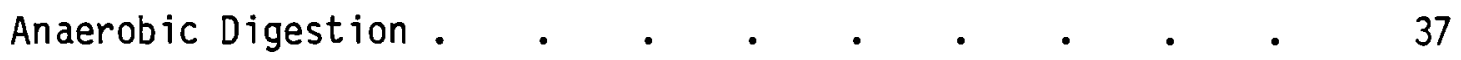

CARBON SORPTION

POWDERED CARBON ADDITION TO ACTIVATED SLUDGE.$\quad$ • $\quad$. $\quad$. 40

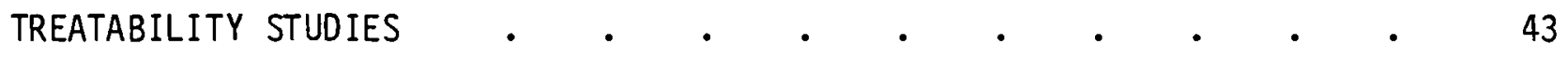

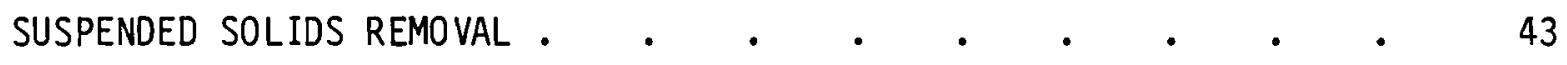

Gravity Sedimentation of Raw Retort Water . . . . $\quad 43$

Chemical Coagulation and Flocculation $\quad$ e $\quad . \quad$. $\quad$. 44

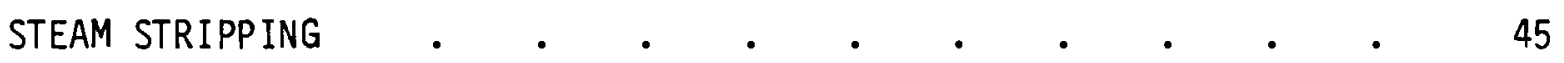

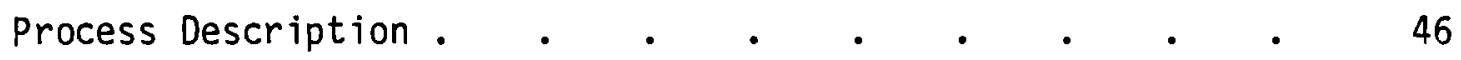

Report Water Stripping . . . . . . . . . 48

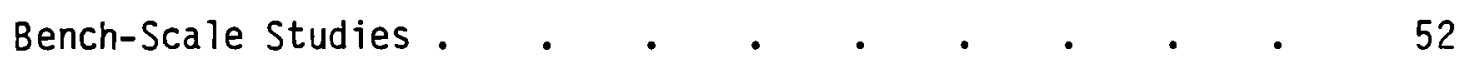

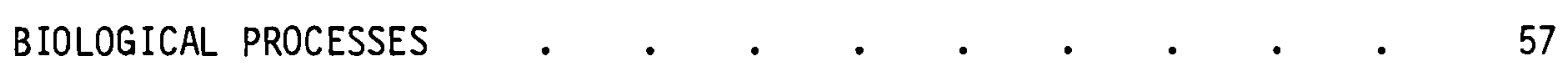

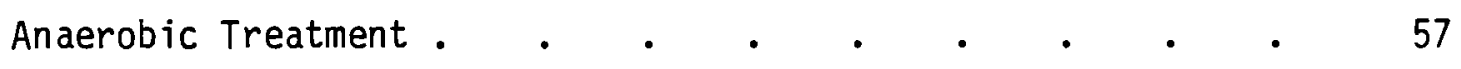

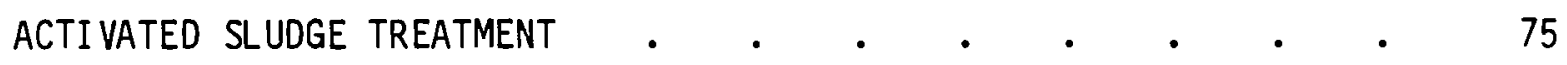

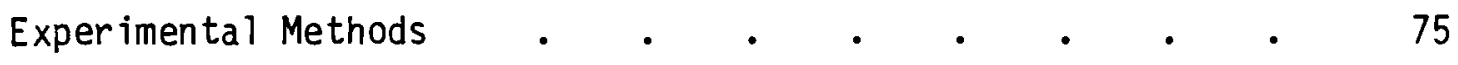

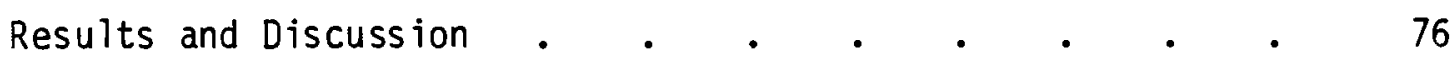




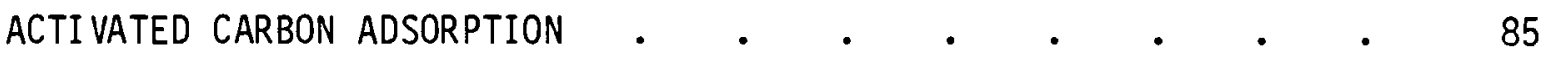

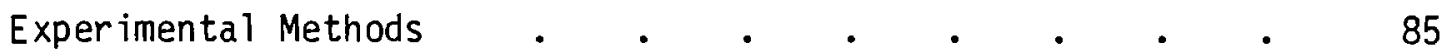

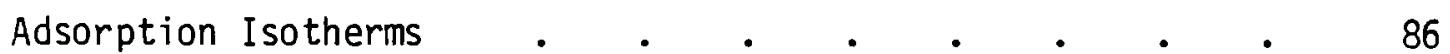

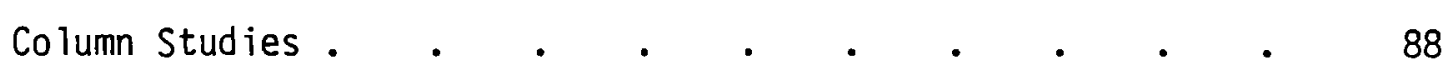

ALUM/POLYMER COAGULATION OF BIOTREATED RETORT WATER $\quad$ • $\quad$ • 89

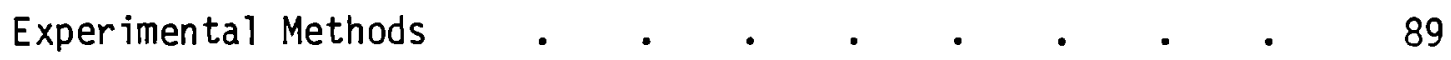

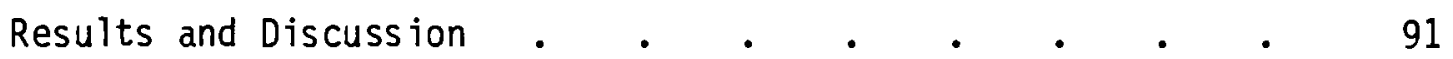

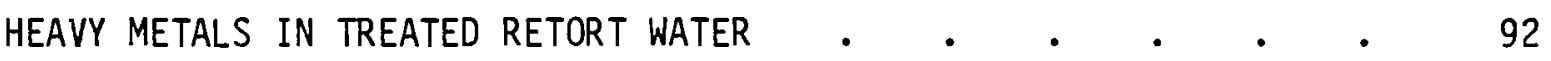

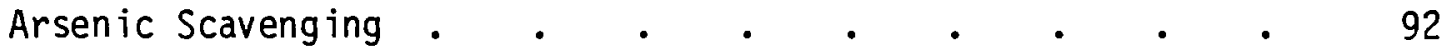

Heavy Metals and Boron in Treated Effluents . $\quad . \quad$. $\quad 94$

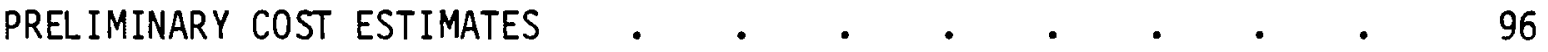

Estimated Costs of Physical-Chemical and
Biological Treatment

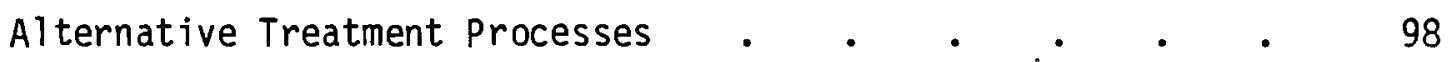

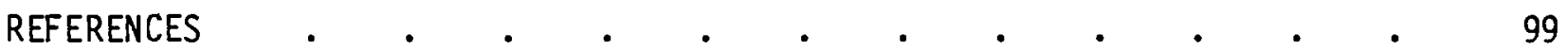

APPENDIX - CAPITAL AND OPERATING COST ESTIMATES FOR PHYSICAL-

CHEMICAL AND BIOLOGICAL TREATMENT OF SHALE OIL

A. 1 


\section{FIGURES}

1 Generic Flowsheet for Removal of Pollutants from

Shale 0 il Retort Wastewater . . . . . . . 22

2 Schematic of API Separator . . . . . . . . . 25

3 Simplified Flow Diagrams of Air Flotation Systems . . . 27

4 Typical Steam Stripping System . . . . . . . 46

5 Effect of Steam-to-Feed Ratio and Number of Stages

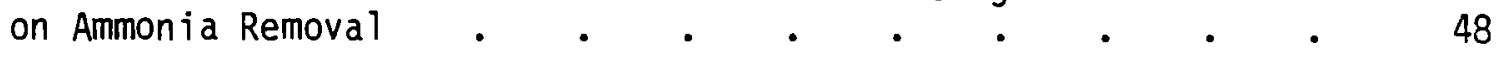

$6 \quad \mathrm{NH}_{3}-\mathrm{CO}_{2}-\mathrm{H}_{2} \mathrm{O}$ system with $0.125 \mathrm{NH}_{3}$ at $20^{\circ} \mathrm{C}$. $\quad . \quad$. 50

7 Partial Pressure of $\mathrm{NH}_{3}$ and $\mathrm{CO}_{2}$ at $20^{\circ} \mathrm{C}$ and $0.125 \mathrm{NH}_{3}$. . 50

8 Mole Fraction of Predominant Chemical Species in $\mathrm{NH}_{3}-\mathrm{CO}_{2}-\mathrm{H}_{2} \mathrm{O}$

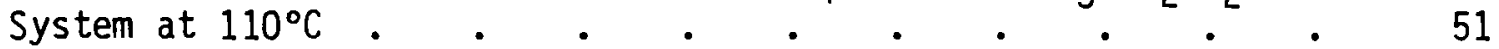

9 Vapor Pressure of $\mathrm{NH}_{3}$ and $\mathrm{CO}_{2}$ at $110^{\circ} \mathrm{C}$ and $0.1 \mathrm{M}$

Total $\mathrm{NH}_{3}$ and Variable $\mathrm{CO}_{2}$ Concentrations . - . . . 52

10 Diagram of Bench-Scale Steam Stripper . . . . . 54

11 Effect of Alkalinity Addition on Ammonia Removal from Simulated In Situ Process Water by Steam Stripping . . . . . 56

12 Rates of Gas Production for the Anaerobic Digestion of Geokinetics Retort Water - Test No. 1 . . . . . 60

13 Total Volatile Acid Concentrations During the Anaerobic Digestion of Geokinetics Retort Water - Test No. 1 . .

14 Rates of Gas Production for the Anaerobic Digestion of Simulated In Situ Retort Water - Test No. 2 . . . .

15 Total Volatile Acid Concentrations During the Anaerobic Digestion of Simulated In Situ Retort Water - Test No. 2 . .

16 Gas Production Per Unit of Volatile Solids Applied for the Anaerobic Digestion of Simulated In Situ Retort Water With Carbon Addition - Test No. 3 . . . . .

17 Gas Production Per Unit of Volatile Solids Applied for the Anaerobic Digestion of Steam-Stripped Geokinetics Retort Water with Carbon Addition 
18 Comparison of Feed and Effluent TOC with TOC/MLVSS Ratio During Activated Sludge Acclimation Experiment .

19 Organic Carbon Influent, Effluent and Loading Values with PAC Treatment

20 Organic Carbon Influent, Effluent and Loading Values Without PAC Treatment.

21 Removal of TOC, COD and Thiocyanate with PAC Treatment . . 82

22 Removal of TOC, COD and Thiocyanate Without PAC Treatment . 83

23 Carbon Adsorption Isotherm for Steam-Stripped

Geokinetics Retort Water . . . . . . . . 88

24 Activated Carbon Treatment TOC Removal . . . . . 89

25 Activated Carbon Treatment COD Removal . . . . . 90 


\section{TABLES}

1 Conventional Pollutant Concentrations in Simulated

In Situ Retort Waters . . . . . . . . . 10

2 Elemental Composition of Simulated In Situ Retort Waters . . 11

3 Conventional Pollutant Concentrations in a True In Situ

Retort Water--Omega 9 Water Composite . . . . . 12

4 Elemental Composition of a True In Situ Retort Water--

Omega 9 Water Composite . . . . . . . . 13

5 Retort Water Analysis From Occidental's D.A. Test

Tract Facility . . . . . . . . . . 14

6 Conventional Pollutant Concentrations in Geokinetics

Retort Water . . . . . . . . . . 15

7 Elemental Analysis of Geokinetics Retort Water . . . . 16

8 Tentative Criteria for Disposal of Shale 0il Effluents

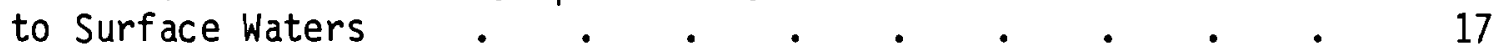

9 Percent Removal of Pollutants by Air Flotation Treatment

of Petroleum Refinery Wastewater . . . . • • 28

10 Effect of Polymer Type and Dosage on Removal of

Suspended Solids from Retort Water . . . . . . . 44

11 Alum Coagulation of Geokinetics Retort Water . . . . 45

12 Ammonia and Carbon Dioxide Removal by Theoretical Stages

in a Steam Stripper Tower . . . . . . . . 53

13 Steam Stripping Results with 2-in. Column . . . . . 55

14 Analys is of Geokinetics Retort Water Used in Test No. 1 . $\quad 59$

15 Analysis of Steam-Stripped Simulated In Situ Retort Water

Used in Test No. $2.0 . \quad . \quad . \quad . \quad . \quad . \quad . \quad 64$

16 Analysis of Paraho Retort Water After Lime Pretreatment and Air Sparging. . . . . . . . . . 70

17 Analysis of Steam-Stripped Geokinetics Retort Water . . . 72

18 Composition of Synthetic Retort Water . . . . . 76 
19 Feed Compositions for Activated Sludge Test Reactors . . $\quad 79$

20 Comparison of Pollutant Removals with Activated Sludge With and Without PAC Treatment . . . . . . . 83

21 Results of Alum/Polymer Coagulation Tests on Biotreated

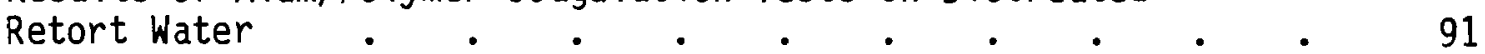

22 Ferric Hydroxide Scavenging of Arsenic Without Manganese Addition . . . . . . . . . . . . . 93

23 Ferric Hydroxide Scavenging of Arsenic with Manganese

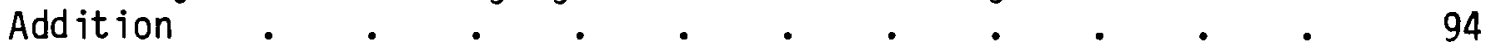

24 Heavy Metals and Boron in Geokinetics

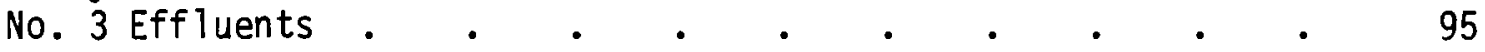

25 Heavy Metals and Boron in Geokinetics

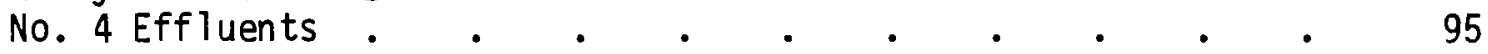

26 Preliminary Cost Estimates for Retort Water Treatment . . . . . . . . . . 
. 
EVALUATION OF PHYSICAL-CHEMICAL AND

BIOLOGICAL TREATMENT OF SHALE OIL RETORT WATER

B. W. Mercer, M. J. Mason, R. R. Spencer, W. Wakami ya and A. L. Wong

\section{INTRODUCTION}

Wastewater that is coproduced and collected with shale oil during the retorting process is commonly referred to as "retort water." Retort water is typically a highly polluted wastewater which, if discharged in large quantities to natural surface receiving waters, would not only place a severe oxygen demand on these receiving waters but would also introduce a substantial load of toxic materials and salinity. However, a number of different options are available for dealing with the problem of retort water management in the developing shale oil industry.

Retort water management was not visualized as a severe problem in the past for surface retorting facilities because it was felt that the water could be used with little or no treatment for moisturizing spent shale. Moisturization is essential for finely divided or powdery spent shale, such as that produced by the Tosco II Process (Whitcombe and Vauter 1976), for compaction of the spent shale at the disposal site. Moisturization is not essential for compaction of coarse types of spent shale, although it helps to some extent. No discharge of retort water is currently anticipated from surface retorting facilities since this water will either be used for moisturizing spent shale or for some other consumptive purpose. It is presently anticipated that some treatment will be required before the retort water is used to moisturize spent shale to minimize the leaching potential of the spent shale piles.

In situ shale oil recovery usually produces more retort water than surface retorting. The ratio of the volume of in situ retort water to that of the oil produced is extremely variable and has been reported to range from 0.4 to over 20 (Farrier et al. 1978). The frequently cited ratio of one barrel of water produced with each barrel of oil represents a considerable volume of 
retort water (over 2 million gallons per day) for an in situ facility producing 50,000 barrels of 011 per day. In the case of a modified in situ operation some of the retort water could be used for spent shale moisturization if a surface retort facility is employed to process shale removed from the subsurface retorts. Retort water can also be used to produce steam for injection into the retorts for enhanced oil recovery. Although reuse without treatment may be possible for some of the retort water, it is anticipated that considerable quantities of this wastewater will be produced if in situ retorting is practiced on a broad scale and particularly if modified in situ methods are used in wet shale zones. Therefore, suitable disposal methods or means of upgrading the quality of the wastewater for additional reuse purposes must be sought to avoid degradation of receiving ground and surface water quality near these facilities.

This report addresses the feasibility of using conventional biological and physical/chemical methods of treating retort water. Available literature sources and contacts within industry provided adequate information in some instances for evaluation of treatment process. In others, particularly biological treatment, bench-scale studies were necessary to provide the required process evaluation data. This report contains the results of bench-scale studies on steam stripping, biological and chemical treatment, and activated carbon adsorption treatment of in situ retort water and an assessment of treatment alternatives. 


\section{SUMMARY AND CONCLUSIONS}

Bench scale studies were conducted to evaluate conventional physicalchemical and biological treatment processes for removal of pollutants from retort water produced by in situ shale oil recovery methods. Prior to undertaking these studies, very little information had been reported on treatment of retort water. A treatment process train patterned after that generally used throughout the petroleum refining industry was envisioned for application to retort water. The treatment train would consist of processes for removing suspended matter, ammonia, biodegradable organics, and nonbiodegradable or refractory organics. The treatment processes evaluated include anaerobic digestion and activated sludge for removal of biodegradable organics and other oxidizable substances; activated carbon adsorption for removal of nonbiodegradable organics; steam stripping for ammonia removal; and chemical coagulation, sedimentation and filtration for removal of suspended matter. The results of these studies are summarized below.

\section{PRELIMINARY COST ESTIMATES}

- Preliminary cost estimates (1980 costs) for treatment of retort water to produce an effluent suitable for cooling towers ranged from $\$ 10.78$ to $\$ 24.75 / 1000 \mathrm{gal}$. These costs trans late to $\$ 0.45$ to $\$ 1.04 /$ barrel of 011 produced at a 1:1 ratio of retort water to 011 .

- The high cost of physical-chemical and biological treatment could adversely affect shale oil production costs. Treatment costs estimated in these studies do not include disposal costs for the cooling tower blowdown which may be classified as hazardous waste if toxicant levels exceed regulatory limitations.

- Alternate methods for treating retort water, especially evaporation, should be considered to achieve a higher quality effluent. Evaporation costs are expected to be.about $\$ 7 / 1000$ gal, but some additional treatment may be required to clean up the condensate. 
Concentrated waste from the evaporator may be on the order of about $5 \%$ of the original volume of retort water and would require disposal (e.g., evaporation pond).

\section{BIOLOGICAL TREATMENT}

- Anaerobic digestion of retort water does not appear practical due to the presence of toxicants which interfere with microbial activity. Digestion of an undiluted simulated in situ retort water was achieved, but a large dose of powdered activated carbon (2000 $\mathrm{mg} / 1$ ) was added to the digester to overcome toxicity problems.

- Anaerobic digestion of Geokinetics in situ retort water from Utah was not possible without dilution. Sulfide poisoning was suspected since relatively high thiosulfate concentrations were present in this waste and this material may be reduced to sulfide in the digester.

- Several initial attempts to acclimate activated sludge cultures to retort water were not successful due to toxicity problems. The high bicarbonate content of the retort water tested results in carbon dioxide stripping in the aeration chamber and $\mathrm{pH}$ levels above optimum for this process.

- Successful acclimation of an activated sludge culture was achieved with careful pH control $(7.0 \pm 0.5)$ and a long acclimation period using activated carbon treated retort water.

- As much as $70 \%$ of the chemical oxygen demand (COD) and $65 \%$ of the total organic carbon (TOC) were removed by activated sludge with $300 \mathrm{mg} / 1$ PAC addition. Consistantly high thiocyanate removal (94\%) was maintained with PAC addition.

- Comparison of activated sludge treatment with and without $300 \mathrm{mg} / 1$ PAC addition under similar loading conditions $(0.71$ to $0.79 \mathrm{lb}$ of COD/lb of mixed liquor volatile solids) did not reveal a significant difference for TOC and COD removal (56 and 66\%, respectively), but thiocyanate removal was superior with PAC addition (99\% versus $72 \%$ ). 
- Thiosulfate, which contributes about $20 \%$ of the COD, was readily oxidized by activated sludge treatment.

- A relatively large quantity of strong mineral acid (e.g., 58 lb of $100 \% \mathrm{H}_{2} \mathrm{SO}_{4} / 1000 \mathrm{gal}$ ) is required to maintain optimum $\mathrm{pH}$ levels for effective activated sludge treatment. Recarbonation with $\mathrm{CO}_{2}$ or stack gas containing $\mathrm{CO}_{2}$ is not practical due to the large bicarbonate concentration in the retort water.

\section{ACTI VATED CARBON ADSORPTION}

- Activated carbon adsorption is much more effective for removing dissolved organic matter from biotreated retort water than nonbiotreated retort water. Isotherm data at $\mathrm{pH} 7$ and $150 \mathrm{mg} / 1$ equilibrium TOC concentration indicate on 1 y $22 \mathrm{mg} / 1$ TOC adsorbed per gram of carbon for nonbiotrated retort water, compared to $100 \mathrm{mg} / 1 \mathrm{TOC}$ adsorbed per gram of carbon for biotreated retort water.

- Activated carbon column results show rapid breakthrough of TOC with nonbiotreated retort water. Breakthrough of $10 \%$ of the feed TOC is reached after 8 bed volumes of nonbiotreated retort water, compared to 50 bed volumes of biotreated retort water.

- Activated carbon adsorption is effective for removal of odor and color, whereas biological treatment has little effect on these parameters.

- Activated carbon adsorption is highly effective for removing copper from biotreated retort water.

\section{STEAM STRIPPING}

- Steam stripping of retort water is considered principally as a pretreatment step for reducing ammonia below toxic levels for aerobic biological treatment. Removal of armonia to very low levels would be required for release of the treated retort water to surface receiving waters, and for certain reuse purposes. 
- Ammonia removals exceeding 95\% were demonstrated in the laboratory with a $5 \mathrm{~cm}$ diameter by $120 \mathrm{~cm}$ high stripping column. Total organic carbon and total alkalinity were also reduced by about $18 \%$ and $70 \%$, respectively.

- The foaming tendency of retort water required careful attention to maintaining low liquid levels in the reboiler of the bench scale stripper to avoid flooding the packed column. Use of outside steam for stripping instead of reboiling may reduce the foaming problem.

- Some fouling of the stripper packing was observed when processing Geokinetics retort water. Use of trays, which can be readily cleaned, may be necessary in a full-scale steam stripper.

- No alkalinity addition was required for steam stripping Geokinetics retort water. Approximately $2 \mathrm{~g} / \mathrm{l}$ of $\mathrm{NaOH}$ was required for attaining near $100 \%$ removal of ammonia from a simulated in situ retort water.

\section{REMOVAL OF SUSPENDED MATTER}

- Only a limited number of tests were conducted on removal of suspended matter from raw retort water because samples of this wastewater were at least two weeks old upon receipt at the laboratory. It is believed that meaningful results for sedimentation and coagulation-flocculation tests can only be obtained using fresh retort water that has been carefully processed to simulate plant operating conditions.

- A cationic polymer appeared to be superior to either an anionic or neutral polymer for promoting suspended solids settling from raw Geokinetics retort water.

- Alum treatment with polymer addition for coagulation and flocculation was not successful for clarifying raw Geokinetics retort water. 
- Biotreated retort water was successfully clarified with $300 \mathrm{mg} / 1$ a lum and $1 \mathrm{mg} / 1$ anionic polymer.

\section{HEAVY METALS SCAVENGING}

- Treatment of steam-stripped Geokinetics retort water with $100 \mathrm{mg} / 1$ $\mathrm{Fe}^{+3}$ (as $\mathrm{FeCl}_{3}$ ) at $\mathrm{pH} 6.0$, or $100 \mathrm{mg} / 1 \mathrm{Fe}^{+3}$ with $32 \mathrm{mg} / 1 \mathrm{Mn}^{+2}$ or $\mathrm{Mn}^{+7}$ at $\mathrm{pH} 7.0$ reduced arsenic from $4.1 \mathrm{mg} / 1$ to less than $1 \mathrm{mg} / 1$. Additional treatment of the same retort water did not reduce arsenic below $0.8 \mathrm{mg} / 1$, which indicates either a complex or organic form of arsenic that is not amenable to precipitation-scavenging by this technique.

- Copper was reduced by a factor of 2.6 by $\mathrm{Fe}(\mathrm{OH})_{3}-\mathrm{MnO}_{2}$ scavenging, but other metals including $\mathrm{Co}, \mathrm{Sb}, \mathrm{Se}$, Mo, and $\mathrm{V}$ were reduced by less than a factor of two.

\section{RECOMMENDED FUTURE RESEARCH}

The difficulties experienced in these studies on acclimating biological cultures to retort water suggests that the biological treatment step would be the weak link in the process train. Additional research is needed to evaluate methods for enhancing biological treatment of retort water.

In view of the high costs estimated for conventional biological and physical-chemical treatment and the low quality of the effluents produced, additional research is needed to evaluate alternate processes. Possible alternatives include evaporation, wet air oxidation, ultrafiltration, reverse osmosis, and solvent extractions. 


\section{RETORT WATER QUALITY AND DISCHARGE/REUSE REQUIREMENTS}

A thorough characterization of retort water is necessary to properly assess the potential application of treatment processes for the removal of pollutants. This section provides a review of available data on the composition of retort water and quality standards for discharge or reuse.

\section{RETORT WATER QUALITY}

Both simulated and actual in situ retort water are analyzed to provide data on the characteristics of in situ retort water.

Simulated In Situ Retort Water

Simulated in situ retorting is generally carried out in an enclosed vessel under a greater degree of control than is possible in the field. Water produced by simulated in situ retorting is derived from combustion of organics, mineral dehydration, and in some instances, from steam injected into the retort. Minimum, maximum, and average concentrations for various constituents in a number of different simulated in situ retort waters have been reported by Fox et al. (1978). The data for conventional pollutant parameters for these waters are given in Table 1, and the data from elemental analyses are given in Table 2. The data in Tables 1 and 2 reveal high concentrations of dissolved electrolytes, alkalinity, organic matter, ammonia, and agents which exert an oxygen demand via chemical or biochemical routes. A substantial portion of the total dissolved organic matter in retort water consists of carboxylic acids. The composition of this wastewater varies widely depending on retorting conditions and the nature of the oil shale being retorted.

\section{Actual In Situ Retort Water}

Average concentrations for conventional pollutant parameters for a true in situ retort water (Omega 9 Water Composite) are presented in Table 3, and elemental data are given in Table 4. The Omega 9 Water Composite was obtained from a field testing operation at Site 9 near Rock Springs, Wyoming (Long et al. 1977). Conventional pollutant parameters for Omega 9 water generally 
TABLE 1. Conventional Pollutant Concentrations in Simulated In Situ Retort Waters (Fox et al. 1978)

Parameter

Alkalinity, total
Alkalinity, bicarbon
Biochemical oxygen
Carbonate (mg/l Ca
Chemical oxygen dem
Hardness
Nitrogen, ammonia
Nitrogen, ammonium
Nitrogen, nitrate
Nitrogen, organic
Nitrogen, Kjeldahl
Organic carbon
Oil and grease
pH, units
Phosphorus
Solids, dissolved
Solids, total
Solids, volatile

Concentration in $\mathrm{mg} / 1$ Unless Noted Otherwise (a)

\begin{tabular}{rrr}
\hline Minimum & Maximum & Average \\
\cline { 3 - 3 } 3,200 & 110,900 & \\
3,440 & 60,400 & \\
0.0 & 25,400 & \\
8,500 & 43,000 & 18,500 \\
20 & 1,500 & 88 \\
1,700 & 13,200 & 7,000 \\
930 & 24,450 & 10,000 \\
1.4 & 8.7 & \\
73.3 & 1,510 & \\
6,600 & 19,500 & \\
2,200 & 19,000 & 4,700 \\
3,800 & 3,800 & \\
8.1 & 9.4 & 8.7 \\
0.23 & 19.0 & 1.25 \\
1,750 & 24,500 & 6,800 \\
6,350 & 121,000 & \\
2,070 & 119,300 & \\
& &
\end{tabular}

(a) The range given is based on the analysis of up to 18 different waters obtained from 4 simulated in situ $0 i 1$ shale retorts. An average value is given only if 15 or more waters were available.

fall within the ranges given for the simulated in situ retort waters given in Table 1. Notable exceptions are alkalinity, organic carbon, $0 i 1$ and grease, and chemical oxygen demands, which are lower for Omega 9 water. Also, native ground water in the Rock Springs area may have contributed a dilution effect. 
TABLE 2. Elemental Composition of Simulated In Situ Retort Waters (Fox et al. 1978)

\begin{tabular}{|c|c|c|c|}
\hline \multirow[b]{2}{*}{ Element } & \multicolumn{3}{|c|}{ Concentration in $\mathrm{mg} / \mathrm{l}^{(\mathrm{a})}$} \\
\hline & Minimum & Maximum & Average \\
\hline Aluminum & 0.041 & 16.6 & \\
\hline Arsenic & 0.46 & 10 & 1.8 \\
\hline Barium & 0.002 & 0.47 & 0.07 \\
\hline Berylium & 0.001 & 0.001 & \\
\hline Bromine & 0.001 & 1.94 & 0.082 \\
\hline Cadmium & 0.001 & 0.005 & \\
\hline Calcium & 0.0 & 94 & 7.6 \\
\hline Chlorine & 0.007 & 1,910 & \\
\hline Chromium & 0.009 & 0.08 & 0.015 \\
\hline Cobalt & 0.002 & 0.65 & 0.12 \\
\hline Copper & 0.003 & 160 & 0.019 \\
\hline Fluoride & 0.1 & 270 & \\
\hline Iodine & 0.001 & 1.3 & \\
\hline Iron & 0.091 & 77 & 7.6 \\
\hline Lead & 0.002 & 0.83 & \\
\hline Lithium & 0.001 & 7.1 & 0.70 \\
\hline Magnes ium & 3.2 & 350 & 22 \\
\hline Manganese & 0.001 & 0.39 & 0.099 \\
\hline Mercury & 0.001 & 0.39 & \\
\hline Mol ybdenum & 0.033 & 1.2 & \\
\hline Nickel & 0.014 & 2.6 & \\
\hline Potassium & 8 & 120 & 37 \\
\hline Selenium & 0.001 & 1.7 & \\
\hline Silver & 0.001 & 0.23 & \\
\hline Sodium & 45 & 1,600 & 320 \\
\hline Sulfur, sulfide, $m g-S^{-} / 1$ & 0.0 & 156 & \\
\hline Sulfur, total, mg-S/l & 14 & 2,320 & \\
\hline Uranium & 0.018 & 93 & \\
\hline Vanadium & 0.004 & 190 & 0.27 \\
\hline Zinc & 0.020 & 15.1 & 0.28 \\
\hline
\end{tabular}

(a) The range given is based on the analysis of up to 18 different waters obtained from 4 simulated in situ oil shale retorts. An average value is given only if 15 or more waters were available. 
TABLE 3. Conventional Pollutant Concentrations in a True In Situ Retort Water--Omega 9 Water Composite (Fox et al. 1978)

\begin{tabular}{lc}
\multicolumn{1}{c}{ Parameter } & $\begin{array}{c}\text { Concentration in mg/1 } \\
\text { Unless Noted Otherwir }\end{array}$ \\
\cline { 1 - 1 } Alkalinity, total $\left(\mathrm{mg} / 1\left(\mathrm{CaCO}_{3}\right)\right.$ & $16,200 \pm 480$ \\
Biochemical oxygen demand, 5 day & $8,100 \pm 5,700$ \\
Chemical oxygen demand & 110 \\
Hardness & $3,795 \pm 390$ \\
Nitrogen, ammonia & $3,470 \pm 830$ \\
Nitrogen, ammonium & 0.17 \\
Nitrogen, nitrate & $148 \pm 630$ \\
Nitrogen, organic & $3,420 \pm 420$ \\
Nitrogen, Kjeldah 1 & $1,003 \pm 192$ \\
Organic carbon & 580 \\
Oil and grease & $8.65 \pm 0.26$ \\
pH, units & $3.2 \pm 2.6$ \\
Phosphorus & $14,210 \pm 193$ \\
Solids, dissolved & $14,210 \pm 120$ \\
Solids, total &
\end{tabular}
(a) Best values determined by a statistical technique in the analys is of results obtained from a multilaboratory, multimethod survey of the Omega 9 sample.

Retort water analys is for a modified in situ test facility (Shangra 1979) is given in Table 5. The lower biochemical oxygen demand (BOD), chemical oxygen demand $(C O D)$, and organic carbon values relative to simulated in situ retort waters reflect a possible dilution effect from input steam. Although retorting was conducted above the water table, steam was injected into the retort which produced about 11 barrels of retort water to one barrel of oil. Conventional pollutant concentrations are presented in Table 6 for five different retort waters obtained from Geokinetics operation in Utah which uses 
TABLE 4. Elemental Composition of a True In Situ Retort Water-Omega 9 Water Composite (Fox et al. 1978)

\begin{tabular}{|c|c|}
\hline Parameter & Concentration in $\mathrm{mg} / \mathrm{l}^{(\mathrm{a})}$ \\
\hline Aluminum & $0.03-19.1$ \\
\hline Arsenic & $1.0 \pm 0.2$ \\
\hline Barium & $0.71 \pm 0.33$ \\
\hline Berylium & 0.006 \\
\hline Bromine & $2.4 \pm 4$ \\
\hline Cadmium & $0.0016 \pm 0.0008$ \\
\hline Calcium & $12 \pm 4$ \\
\hline Chlorine & $824 \pm 61$ \\
\hline Chromium & $0.02 \pm 4 \%$ \\
\hline Cobalt & $0.030 \pm 0.012$ \\
\hline Copper & $0.10 \pm 0.04$ \\
\hline Fluorine & $60 \pm 9$ \\
\hline Iodine & $0.59 \pm 0.30$ \\
\hline Iron & $1.2 \pm 0.30$ \\
\hline Lead & $0.0045-0.02$ \\
\hline Lithium & $0.18-0.8$ \\
\hline Magnes ium & $20 \pm 6$ \\
\hline Manganese & $0.09 \pm 0.04$ \\
\hline Mercury & $0.0003-0.021$ \\
\hline Molybdenum & $0.60 \pm 0.07$ \\
\hline Nickel & $0.06 \pm 0.02$ \\
\hline Potassium & $47 \pm 9$ \\
\hline Selenium & $0.21 \pm 0.11$ \\
\hline Silver & $0.003 \pm 0.001$ \\
\hline Sodium & $4,333 \pm 244$ \\
\hline Sulfur, sulfate, $\mathrm{mg}-\mathrm{SO}_{4 / 1}$ & $1,990 \pm 250$ \\
\hline Sulfur, sulfide, mg-5 -1 & 0.0 \\
\hline Sulfur, total, mg-S/l & 2,010 \\
\hline Uranium & $0.55 \pm 0.07$ \\
\hline Vanadium & $0.12 \pm 0.01$ \\
\hline Zinc & $0.31 \pm 0.04$ \\
\hline
\end{tabular}

(a) Best values determined by a statistical technique in the analysis of results obtained from a multilaboratory, multimethod survey of the Omega 9 sample. 
TABLE 5. Retort Water Analys is From Occidental's

D.A. Test Tract Facility (Shangra 1979)

\begin{tabular}{|c|c|c|c|}
\hline \multirow[b]{2}{*}{ Parameters } & \multicolumn{3}{|c|}{$\begin{array}{l}\text { Concentration in } \mathrm{mg} / \mathrm{l} \\
\text { Unless Noted Otherwise } \\
\end{array}$} \\
\hline & Average & Maximum & Min imum \\
\hline Alkalinity, total $\left(\mathrm{mg} / 1 \mathrm{CaCO}_{3}\right)$ & 10,650 & 12,900 & 6,300 \\
\hline Alkalinity, bicarbonate $\left(\mathrm{mg} / 1 \mathrm{CaCO}_{3}\right)$ & 8,012 & 9,800 & 4,700 \\
\hline Biochemical 0xygen Demand & 425 & 580 & 310 \\
\hline Chemical Oxygen Demand & 3,006 & 5,260 & 1,800 \\
\hline Nitrogen, Ammonia & 1,200 & 1,500 & 980 \\
\hline Nitrogen, Kjeldahl & 1,624 & 2,370 & 1,050 \\
\hline Organic carbon & 1,023 & 1,310 & 720 \\
\hline $0 i 1$ and Grease & 154 & 340 & 28 \\
\hline $\mathrm{pH}$, Units & 8.5 & 8.7 & 8.4 \\
\hline Sulf ate & 1,268 & 2,060 & 1,000 \\
\hline Sodium & 3,540 & 3,800 & 3,300 \\
\hline Potassium & 92.6 & 100 & 76 \\
\hline Lithium & 2.0 & 2.0 & 2.0 \\
\hline Bromine & 2.0 & 2.0 & 2.0 \\
\hline Volatile Solids & 32.6 & 50 & 15 \\
\hline Boron & 19.5 & 24 & 17 \\
\hline
\end{tabular}

horizontal in situ retorting. This operation is carried out by blasting shale deposits near the surface to cause surface uplift, thereby fracturing and increasing the permeability of the shale zone to be retorted. Retorting is carried out above the water table and steam is not injected in the retorts. Elemental analyses for Geokinetics in situ water are presented in Table 7. Organic carbon, BOD, and COD concentrations in this water tend to fall in the range given in Table 1 for simulated in situ retort waters which reflects a lower potential for dilution by waters outside of those produced by organic combustion and mineral dehydration. 
TABLE 6. Conventional Pollutant Concentrations in Geokinetics Retort Water

\begin{tabular}{lrrr}
\multicolumn{1}{c}{ Parameters } & & Minimum & $\frac{\text { Maximum }}{n n n}$ \\
Alkalinity, total (mg/1 $\left.\mathrm{CaCO}_{3}\right)$ & & 7,900 & 17,500 \\
Biochemical Oxygen Demand, 5 Day & & 1,600 & 3,400 \\
Chemical Oxygen Demand & & 5,000 & 15,400 \\
Conductivity, umhos/cm & 18,000 & 24,000 \\
Nitrogen, Ammonia & 840 & 3,060 \\
Nitrogen, Kjeldahl & 1,100 & 5,800 \\
Organic Carbon & 1,362 & 2,600 \\
PH, units & 8.6 & 9.4 \\
Phosphorus & 0.3 & 0.5 \\
Solids, dissolved & 13,200 & 18,200 \\
Solids, total & 13,400 & 18,400
\end{tabular}

The high thiosulfate concentrations given in Table 7 are of interest because of the oxygen demand exerted by this noncarbonaceous reducing agent. Approximately $20 \%$ of the $\mathrm{COD}$ and $35 \%$ of the BOD was contributed by thiosulfate. Furthermore, the standard BOD test for retort water may fail to include the thiosulfate contribution unless special precautions are taken for seed development (Wong and Mercer 1979).

\section{WATER QUALITY REQUIREMENTS}

Water quality requirements involve limitations for both discharge and reuse.

Discharge Limitations

Sufficient wastewater treatment data were not available to develop guidelines for disposal of retort or process wastewater to surface receiving waters. Instead, tentative criteria were established based on State standards (Table 8). Except for total dissolved solids, these values are taken from 
TABLE 7. Elemental Analysis of Geokinetics Retort water

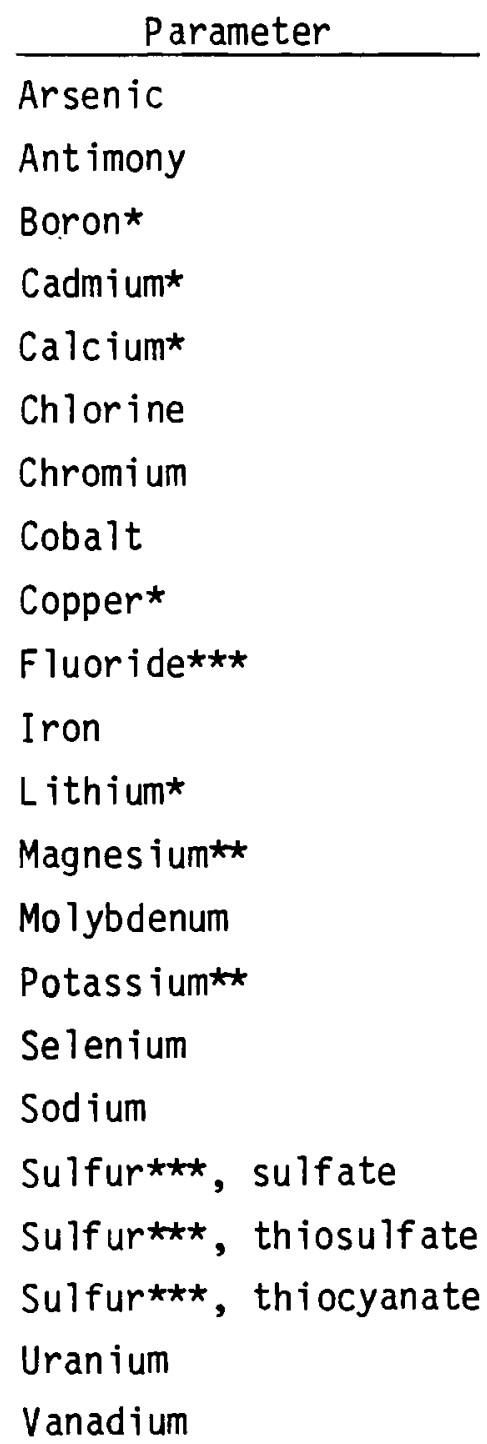

\begin{tabular}{cc} 
Concentration ${ }^{(\mathrm{a})}$ Minimum $\mathrm{mg} / 1$ \\
\hline 4.1 & $\frac{\text { Maximum }}{19.2}$ \\
0.13 & 0.33 \\
85 & 120 \\
$<0.01$ & $<0.01$ \\
$<1$ & 8.7 \\
130 & 150 \\
$<0.07$ & 0.1 \\
0.12 & 0.36 \\
$<0.01$ & 0.33 \\
28 & 29 \\
$<5$ & 8 \\
0.20 & 0.48 \\
15 & 100 \\
1.5 & 8.4 \\
89 & 230 \\
0.22 & 0.31 \\
2200 & 6320 \\
250 & 550 \\
814 & 1320 \\
127 & 163 \\
0.12 & 0.17 \\
$<0.08$ & 0.1
\end{tabular}

(a) Determined by neutron activation except where marked by asterisks.

* Analyzed by plasma emission spectroscopy.

* Analyzed by atomic absorption.

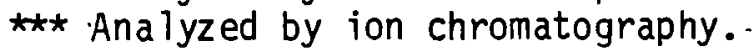


TABLE 8. Tentative Criteria for Disposal of Shale $0 i 1$ Effluents to Surface Waters

\begin{tabular}{|c|c|c|}
\hline No. & Parameter & Limitation \\
\hline 1 & $\mathrm{BOD}_{5}$ & $30 \mathrm{mg} / 1$ \\
\hline 2 & Suspended Solids & $30 \mathrm{mg} / 1$ \\
\hline 3 & $0 i 1$ and Grease & $10 \mathrm{mg} / \mathrm{l}$ and no visible sheen \\
\hline 4 & pH & 6.0 to 9.0 \\
\hline 5 & Settleable Solids & essentially free from \\
\hline 6 & Floating Solids & essentially free from \\
\hline 7 & Taste, Odor, Color & essentially free from \\
\hline 8 & Toxic Materials & essentially free from \\
\hline 9 & Total Dissolved Solids & $500 \mathrm{mg} / 1$ \\
\hline
\end{tabular}

\begin{abstract}
Note: Numbers 1-4 above provide spec if ic limitations for discharge of wastes not covered by other industrial effluent limitation guidelines in the State of Colorado. Numbers 5-8 are standards applicable to receiving waters for Colorado, Utah, and Wyoming. Number 9 is the average total dissolved solids in the Colorado River at Grand Valley, Colorado.
\end{abstract}

water quality standards and effluent limitations for the states most likely to be involved in shale oil development (Colorado, Utah, and Wyoming). The limitation of $500 \mathrm{mg} / 1$ for total dissolved solids represents an average value for the Colorado River at Grand Valley, Colorado, which is in the vicinity of several planned commercial shale oil recovery operations.

Based on the criteria given in Table 8 , discharge of untreated retort water to natural surface receiving waters would be unacceptable for a number of reasons. Retort water has a foul taste and odor and a color varying from light to dark brown. Ammonia probably represents the greatest toxicity problem to aquatic life because of its relatively high concentration. In many cases tenfold dilutions would not be sufficient to reduce arsenic, fluoride, or boron below drinking water or irrigation water quality limitations. 
Discharge by underground injection or land disposal has been investigated by Mercer et al. (1979). The results of the study indicated that underground injection is a viable disposal method for shale oil wastewaters where geological conditions are favorable; however, regulatory restraints are expected to limit its use for disposal of highly polluted shale oil waters. Proof of confinement of injected wastes will be required to assure protection of drinking water resources, and this is often difficult and expensive to accomplish. Pretreatment to remove suspended solids would be a minimum requirement for underground injection.

The concentrations of dissolved salts and toxic substances (e.g., boron) are considered too high for irrigation of cover crops needed for effective stabilization by land disposal. Additional problems which may arise with land disposal include air pollution from volatile organics and groundwater pollution from refractory organics and dissolved salts.

Potential limitations of disposing retort water to solar evaporation ponds include volatile organics and ammonia which may cause air pollution problems. Ultimately, the concentrate or sludge from the solar evaporation ponds would have to be disposed in a manner consistent with the regulations to be promulgated under the Resources Conservation and Recovery Act (RCRA) of 1976. The presence of soluble toxic substances, such as arsenic and selenium, in the retort water concentrate may render this material hazardous and require special disposal methods to meet RCRA requirements.

Reuse Limitations

Reuse of retort water is possible with little or no treatment for the generation of low pressure steam for injection into an in situ retorting. volatile constituents evaporated along with the water are recycled back to the retorted zone with the steam.

Reuse of retort water with little or no treatment is also possible for moistening spent shale produced from surface retorts operating in conjunction with modified in situ retorts. The ramifications of adding untreated retort water to the spent shale prior to disposal have not been fully explored. 
Reuse of retort water as cooling water has been proposed; however, expensive treatment prior to this use would be required. Furthermore, the salinity of the water would be corrosive to conventional materials such as carbon steel used in cooling systems. Corrosion problems can be circumvented, however, by using materials that resist corrosion (e.g., titanium) in a saline environment. The stripping of volatile substances such as toxic or foul-smelling organics from the retort water in a cooling tower places a limitation on the amount of these substances that could be tolerated from an atmospheric pollution standpoint. Reduction of BOD concentrations would probably be required to control slime growths in the cooling system. Chlorine addition to control slime growths would be very costly because of the high concentrations of reducing substances (e.g., thiosulfate) in the retort water. 


\section{WASTEWATER TREATMENT ALTERNATIVES}

A variety of possible wastewater treatment processes are available for evaluation, but many of these processes are in the research and development stage. The following evaluation of alternatives focuses largely on demonstrated technology, principally that used in the treatment of petroleum refinery wastes. Although shale oil retort water differs considerably in composition from petroleum refinery wastewater, there are enough similarities that the same treatment technology with some variation may be used for both types of wastewaters.

\section{CONCEPTUAL FLOWSHEET}

A conceptual flowsheet for the removal of pollutants from shale oil retort wastewater is presented in Figure 1. This flowsheet assumes a high level of pollutants removal to permit release to surface streams. Portions of the flowsheet may be used for lower levels of treatment to render the water acceptable for the other uses such as cooling water. The flowsheet shows equalization as the first step to minimize fluctuations in the pollutant content of the wastewater feed. Rapid changes in feed concentrations can cause serious impairment of several of the processing steps shown in Figure 1. The first liquid-solids separation step accomplishes removal of suspended solids and oil by gravity separation processes such as sedimentation and flotation. This removal step often substantially reduces the biochemical oxygen demand (BOD) and suspended solids load on biological process and also removes materials which would interfere with other processes.

Ammonia and carbonate/bicarbonate alkalinity are major pollutants in the retort wastewater, and ammonia removal and recovery represents a possible cost recovery step because ammonia is valuable as a fertilizer. Chemical treatment is included to remove toxicants such as arsenic. Biological treatment is generally a relatively low cost method of removing organics and is widely used throughout industry for this purpose. Liquid solids separation following biological treatment is needed to clarify the waste for carbon sorption which is included to remove organic substances not amenable to biological treatment. 


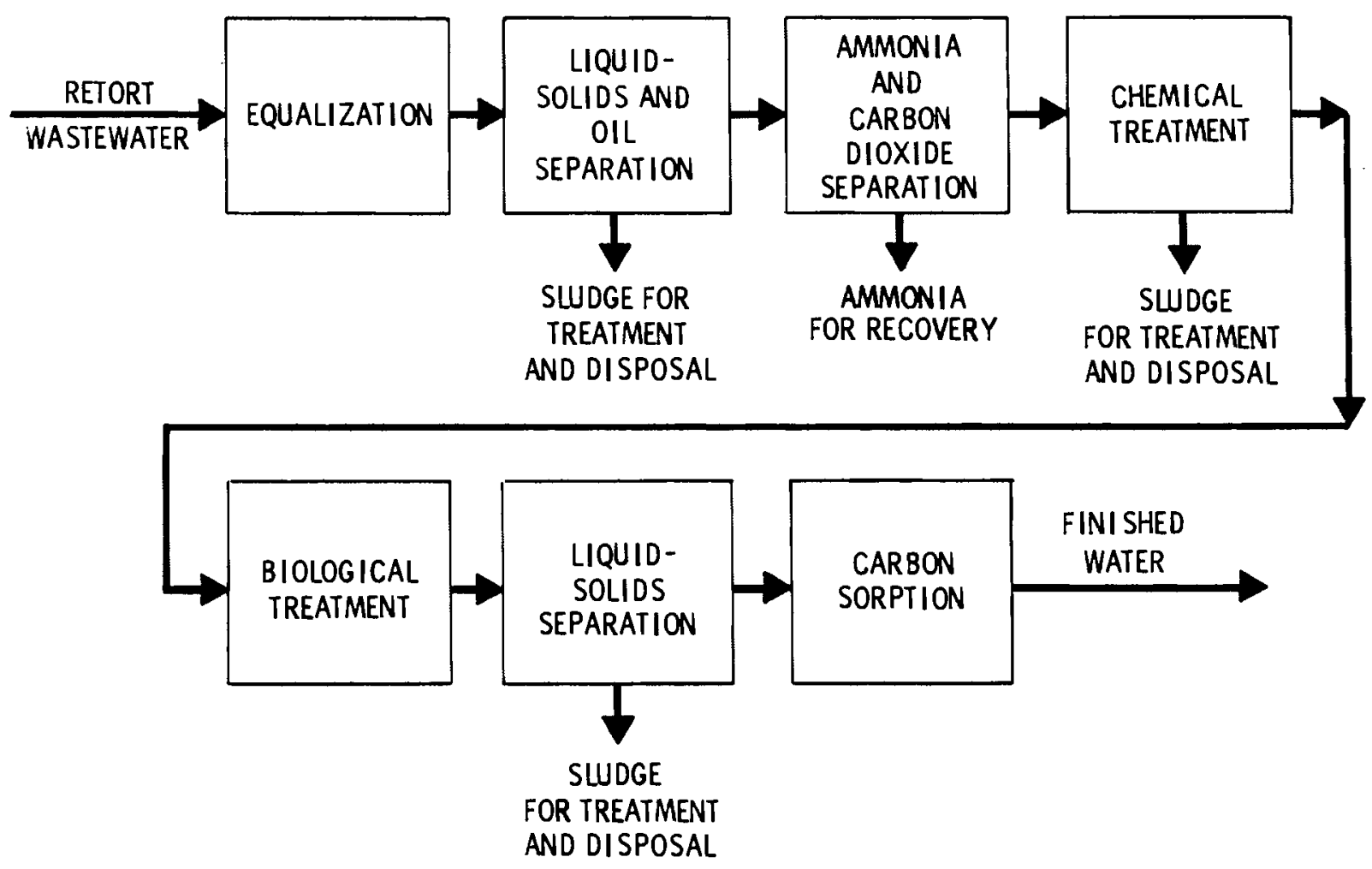

FIGURE 1. Generic Flowsheet for Removal of Pollutants from Shale 0 il Retort Wastewater

Detailed descriptions of the processes which may be used in the generic flowsheet are given in the following sections.

REMOVAL OF RESIDUAL SUSPENDED OILS AND SOLIDS

The separation of retort water from shale $0 i 1$ by decantation following the retorting process may not be completely effective in a full-scale plant operation. It is anticipated that some residual suspended or floating oil will be found in the separated retort water. In addition, some suspended solids, such as mineral matter or precipitated material, will likely be present. Generally, good treatment practice will involve the removal of suspended oils and solids prior to further treatment for removal of dissolved or colloidal matter in the wastewater. The presence of hydrocarbons, for example, can seriously impair the operation of a steam stripper for hydrogen sulfide and/or ammonia removal (Rodriguez 1974). 


\section{Gravity Separation}

The removal of suspended matter by gravity separation is cormonly referred to as primary treatment. Gravity separation depends on the difference in the specific gravity between water and the oil and solids contained therein. In the case of small or intermittent flows of wastewater, separation can often be accomplished on a batch basis in a tank or bas in where quiescent conditions can be maintained for a period of time. For large, continuous flows of oily wastewater, a treatment unit such as an API gravity separator (API 1963) is typically used. Gravity-type separators have been used in the petroleum industry for many years to remove suspended $0 i 1$ and solids from wastewater.

The nature and quantity of oily wastewater to be processed governs the design of the gravity separator to be used. The effectiveness of separation depends on a number of factors including the temperature of the wastewater, the quantity and characteristics of the suspended matter, and the density of the oil droplets (Baum and Prather 1971). Separation will be accomplished on ly if the light matter floats to the surface and the heavy matter sinks to the bottom of the separator. The floating and sinking of the suspended material must occur in a reasonably short period of time to make the process equipment practical to use. Very fine suspended matter, emulsions, and colloids are not removed by a typical gravity separator without some additional treatment such as chemical coagulation.

Research and experience in operating gravity separators has led to a recormended procedure for the design of the API gravity type separators (Rodriguez 1974). This separator is a rectangular vessel consisting of one or more compartments equipped with oil skimmers, flight scrapers, sumps, and other components as shown in Figure 2. Flight scrapers and skimmers remove the oil that floats to the surface of the wastewater, and sediment scrapers remove solids that sink to the bottom of the separator.

Gravity separators of circular design are also used for treating oily wastewater (Baum and Prather 1971). The raw wastewater generally enters a stilling well in the center of the circular separator and flows outward to the 
periphery of the unit. The separated water flows under a deep curtain baffle near the periphery then rises to the surface and overflows a weir. The circular units generally use skimmers to remove oil and other floating matter and sediment scrapers to collect settled sludge.

Air Flotation

0 ily wastewaters frequently contain substantial amounts of suspended matter which has a specific gravity very near that of the wastewater. For this reason these suspended particles will neither sink nor float in a reasonable period of time for gravity separation. The air flotation process was developed as a means of causing these particles to float to the surface for effective removal in a short length of time (Baum and Prather 1971; Thackston 1972; Hart 1970a). In this method, tiny air bubbles become attached to the particles to provide the desired buoyancy.

There are two approaches to generating the air bubbles: pressurizing the total feed with air or pressurizing a clarified recycle stream with air. The first approach involves retention of the feed stream in a tank in contact with air typically at 30 to $50 \mathrm{psig}$ for 1 to $2 \mathrm{~min}$. The feed stream then flows through a pressure relief valve to blend with the wastewater in a flotation chamber. The pressurization of air in the contact tank causes dissolution of air in the water above saturation values at atmospheric pressure. When the reduction of pressure occurs in the flotation chamber, microscopic air bubbles are released which attach themselves to the suspended particles. This action results in agglomerates formed in oily wastewater which have vertical rise rates of 0.5 to $1.0 \mathrm{ft} / \mathrm{sec}$, and quickly come to the surface to form a froth layer (Baum and Prather 1971). This froth layer is cont inuously removed by specially designed flight scrapers. Commercially available air flotation units have chambers designed for retention times generally in the range of 10 to $15 \mathrm{~min}$.

The second approach to generating the tiny air bubbles involves recycling a portion of the clarified wastewater from the flotation chamber through an air contact tank to dissolve an excess of air in the water. This stream is 


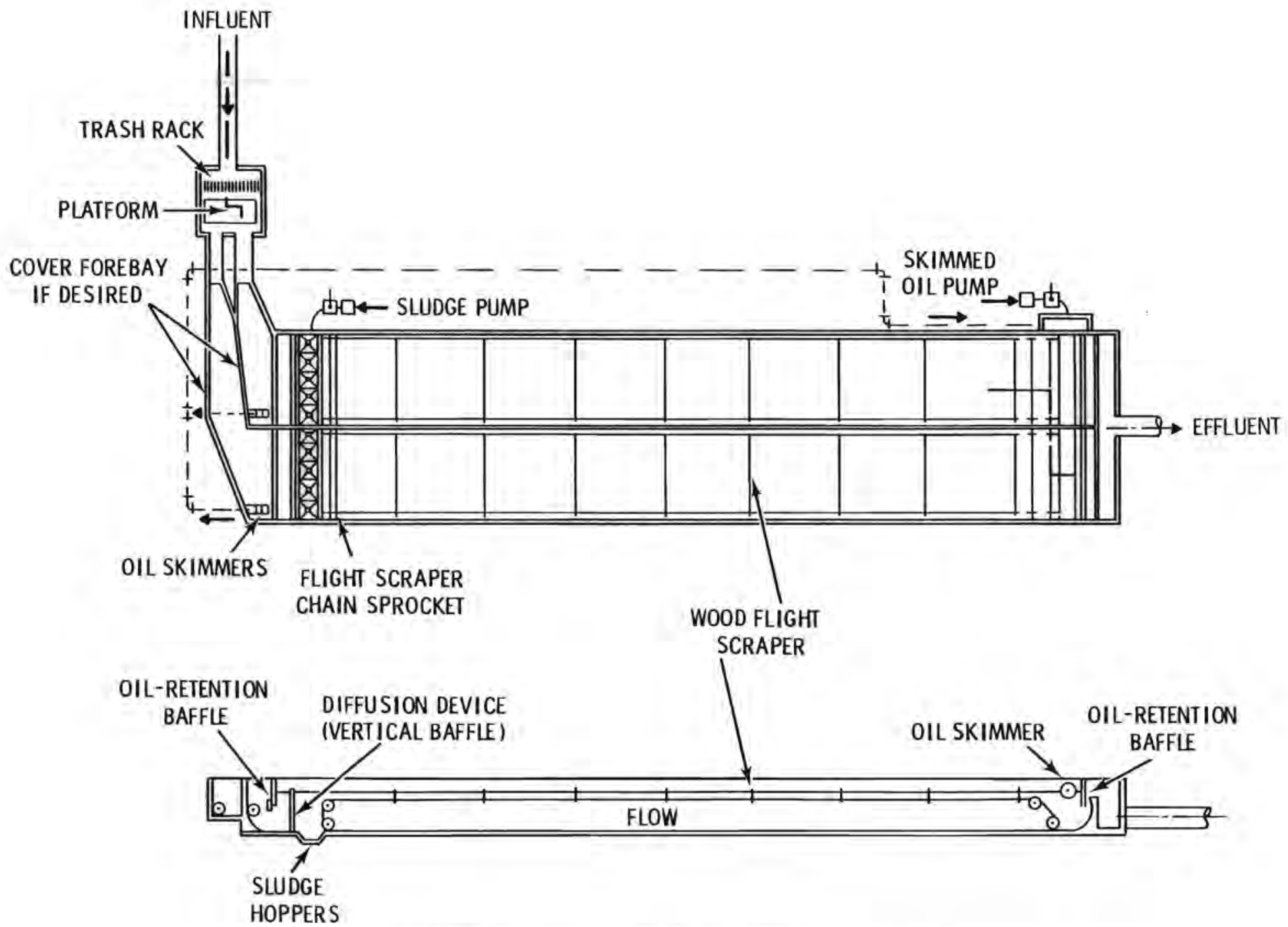

FIGURE 2. Schematic of API Separator 
then released at various points in the flotation chamber where the air bubbles formed can attach themselves to the suspended particular matter.

A variety of methods have been found useful in the injection of air into the wastewater feed or recycle stream. For example, the air may be dissolved by aeration under pressure or by shearing air into small bubbles with the pump impeller where air is introduced o the suction side of the pump feeding to the pressure retention tank. Simplified flow diagrams of these two approaches to air flotation treatment are given in Figures $3 a$ and $3 b$.

Chemical flocculating agents (discussed further in next subsection) are frequently used to improve the performance of the air flotation process. The effectiveness of the flotation process depends on the attraction forces between the air bubble and the particle to be removed. The attraction forces are a function of the characteristics of the particle surface. Chemical coagulation and/or flocculation, such as treatment with alum and/or polyelectrotytes, is very useful in some cases to enhance the attachment of air bubbles to the particulate matter that is agglomerated.

No results are available on air flotation treatment of retort water from shale oil processing. Results of tests on full-scale air flotation treatment units used on petroleum refinery wastewater with and without the use of a polyelectrotyte flocculant are presented in Table 9.

Air flotation may be a very effective process for shale oil retort water treatment; however, successful application will depend on the nature of this wastewater and its response to chemical coagulation and/or flocculating if needed. Temperature, chemical dosage, alkalinity, and reaction or flocculation time will govern the degree to which this approach will remove suspended $0 i 1$ and solids along with associated BOD and COD. Air flotation will generally not supplement gravity separation but can often be very effective in conjunction with gravity separation. 


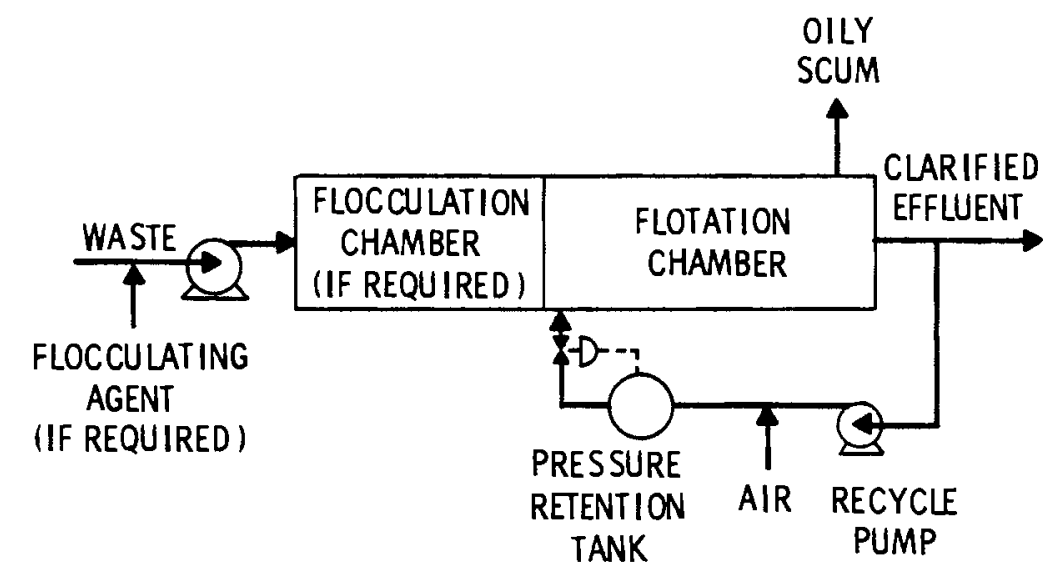

A. RECYCLE

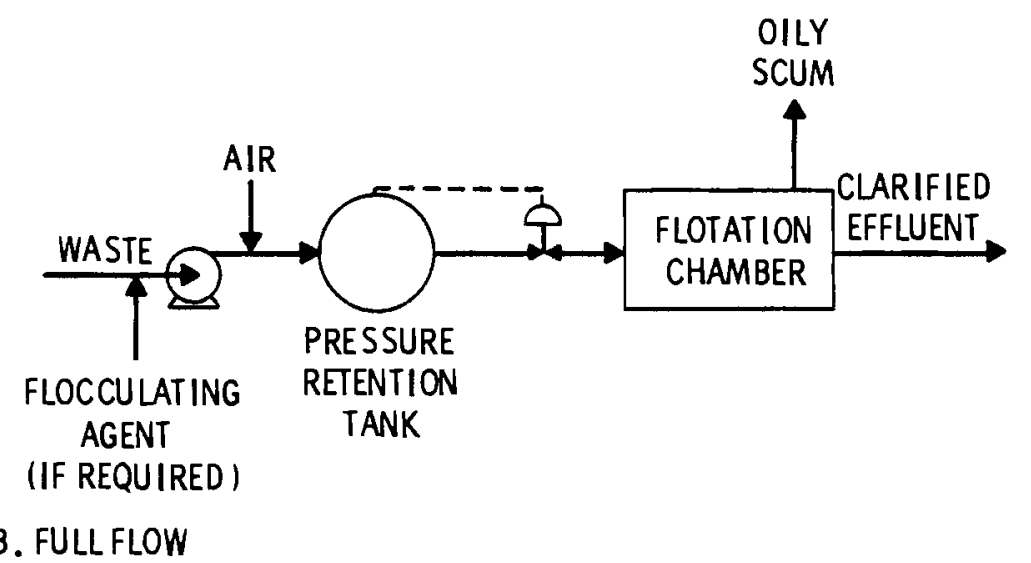

FIGURE 3. Simplified Flow Diagrams of Air Flotation Systems

Chemical Coagulation/Flocculation

Chemical coagulation can be used effectively for air flotation of suspended matter. However, it is more frequently used in the general wastewater treatment field to enhance or make possible sedimentation or filtration of suspended matter.

The function of coagulation/flocculation of wastewater is the removal of suspended solids by destabilization and coagulation of colloidal matter. Colloidal suspensions consist of very fine particles which carry an electric charge on their surfaces. The particles are repelled from one another by this charge which causes them to remain in suspension. The stability of colloidal suspensions in water is based on the ability of the particles to retain the 
TABLE 9. Percent Removal of Pollutants by Air Flotation Treatment of Petroleum Refinery Wastewater (Hart 1970)

\begin{tabular}{|c|c|c|c|c|}
\hline \multirow[b]{2}{*}{ Average of 6 Test Runs } & \multicolumn{4}{|c|}{ Pollutant Concentrations, $\mathrm{mg} / \mathrm{l}$} \\
\hline & $\underline{0 i 1}$ & $\begin{array}{c}\text { Suspended } \\
\text { Solids } \\
\end{array}$ & $\mathrm{COD}$ & $\mathrm{BOD}$ \\
\hline Influent & 18.1 & 63.0 & 359 & 117 \\
\hline Effluent & 6.3 & 28.2 & 253 & 79 \\
\hline Percent Removal & 65.0 & 55.2 & 29.5 & 32.5 \\
\hline
\end{tabular}

\begin{tabular}{|c|c|c|c|c|}
\hline \multirow[b]{2}{*}{ Average of 4 Test Runs } & \multicolumn{4}{|c|}{$\frac{\text { Pollutant Concentrations, mg } / 1}{\text { Suspended }}$} \\
\hline & $0 i 1$ & $\begin{array}{l}\text { Suspended } \\
\text { Solids }\end{array}$ & $\mathrm{COD}$ & $\mathrm{BOD}$ \\
\hline Influent & 11.0 & 37.0 & 224 & 98 \\
\hline Effluent & 2.3 & 9.0 & 131 & 60 \\
\hline Percent Removal & 79.1 & 75.7 & 41.5 & 39.8 \\
\hline
\end{tabular}

surface charge. This charge must be overcome in order to destabilize the suspension and allow the particles to aggregate (coagulate) and form larger particles ( $f l o c)$ that settle easily.

Particle aggregation (destabilization) is brought about by overcoming the effect of the electrical charge or reducing the charge. This may be accomplished by adding electrolytes or long-chained organic molecules (polymers) with ionizable subunits. Destabilization may also be brought about by the addition of chemicals that form hydrolyzed metal ions. Chemicals commonly used in wastewater coagulation are aluminum sulfate (alum), lime, or iron salts such as ferric chloride. Alum and lime both offer the potential of coagulant recovery, while no practical means of recovery of iron salts has yet been demonstrated.

For flocculation, coagulating chemicals must be added to the wastewater, mixed, then gently stirred. Detention times, amounts of chemical, and the type and amount of mixing vary with the chemical used and the character of the wastewater. Difficulties are encountered in coagulation and flocculation when wastewater temperature approaches $0^{\circ} \mathrm{C}$. The settling characteristics of the 
floc become poor, and the tendency of floc to penetrate any filtering media increases, suggesting the floc strength has decreased. It has been observed that the optimal $\mathrm{pH}$ value is decreased by decreases in temperature and that this shift becomes more important with smaller coagulant doses.

Very little information is available on chemical coagulation of shale oil retort wastewater. Hubbard (1971) reported the use of lime to treat the waste and effected some removal of organics (amount not reported) in addition to carbonates by precipitation. Ammonia was also liberated and removed by boiling. The use of 1 ime treatment on retort water was also reported by 0ssio et al. (1978) Calcium hydroxide was added to $\mathrm{pH} 11$ and flotable matter was skimmed off following aeration to strip ammonia. This treatment effected removals of $45 \%$ of the BOD, $73 \%$ volatile acids $55 \%$ of the organic carbon (TOC) and $96 \%$ of the ammonia. It was believed that fatty acids in the retort water were precipitated and removed by skimming to account for a substantial portion of the BOD, volatile acids, and TOC reductions achieved.

Lime treatment would probably be most effectively used after steam stripping which removes most of the ammonia and bicarbonate/carbonate. If lime proved to be very effective for removing organics either by coagulation of precipitation or both, this method of treatment could be incorporated into an integrated scheme with other processes. For example, lime treatment after armonia and carbon dioxide stripping might cause a large BOD reduction to facilitate biological and/or carbon sorption processes for organic removal. Additional experimental data would be required to establish the practicality of this approach.

Lime recovery could be practiced by calcining the calcium carbonate sludges produced. Energy required for the calcining operation may be available from excess combustible retort gases and from precipitated or coagulated organics in the calcium carbonate sludge. This approach may reduce the cost of chemical addition as well as serving as a sludge disposal scheme. 


\section{Filtration}

Filtration is typically used in wastewater treatment as a polishing step to remove residual suspended matter carried over in the effluent from a sedimentation basin or air flotation unit.

Direct filtration of wastewater without removing oils, greases, tars, or other agglomerating substances could seriously impair the performance of rapid sand or similar porous media filters. The agglomerating substances may cause caking and sealing of the filter media which could not be restored for effective use by backwashing. However, rapid sand or multimedia filtration of residual suspended matter following a chemical coagulation of oil emulsions and other suspended matter may be feasible since the agglomerating character of the suspended solids would probably be mitigated in most instances. Biological treatment followed by chemical coagulation, sedimentation, and filtration would be expected to reduce the filter media agglomeration problem even further. This sequence of treatment steps is frequently used prior to activated carbon sorption to achieve a high degree of treatment. The biological treatment step removes biodegradable organics; the chemical coagulation, sedimentation, and filtration step removes particulate matter including organics in the form of biological sludge; and the activated carbon step removes soluble refractory organics which are not removed biologically. Filtration also allows the feed to the activated carbon columns to be relatively free of particulate matter.

The mechanisms involved in the removal of suspended or colloidal material from wastewater by filtration are complex and interrelated. The dominant mechanisms depend on the physical and chemical characteristics of the particulate matter and filtering medium, the rate of filtration, and the biological/ chemical characteristics of the water. The mechanisms responsible for the removal of particulate matter will vary with each treatment system.

The processes by which solids are filtered from wastewater may be generally classified into two categories: adhesion and straining. Adhesion involves the physical/chemical process of particle adsorption on the surface 
of the filtering medium. Straining action takes place in the filter media at restrictions in the pores (minute openings in the filter). All particles larger than these openings will be trapped and held back.

\section{AMMONIA REMOVAL}

Ammonia and bicarbonate are typically major constituents of shale oil retort water. Removal of the ammonia from the retort water may be important for several reasons: 1) recovery may be desired due to its commercial value; 2) ammonia is toxic to fish and other aquatic life forms; 3 ) ammonia is a plant nutrient which could promote undesirable algae growth in the receiving waters; and 4) large concentrations of ammonium ion would interfere with biological treatment processes. Laboratory tests have shown that an ammonia concentration exceeding $4000 \mathrm{mg} / 1$ in a coke plant wastewater severely inhibited the growth of biological sludge (Kostenbader and Flecksteiner 1969).

The three principal methods for removing relatively high concentrations of ammonia from wastewaters are steam stripping, air stripping, and ion exchange.

\section{Steam Stripping}

Steam stripping is the conventional method of removing relatively high concentrations of ammonia from petroleum refinery sour water (Hart 1970; Annessen and Gould 1971; Klett 1972) and from aqueous distillates or liquors from coking plants (Gernham 1965). Coking plants supplied a large fraction of the agricultural nitrogen fertilizer used in the United States prior to the advent of the large ammonia synthesis plants.

Steam stripping retort water for ammonia removal may differ from steam stripping sour water in that a large concentration of bicarbonate is frequently found in retort water but not in sour water. In addition, sour water typically has a large concentration of sulfide not normally found in retort water. Liming shale oil retort water would greatly aid in increasing the volatility of the ammonia by converting the ammonium ion to free ammonia; however, a considerable quantity of lime would be required to accomplish the 
desired $\mathrm{pH}$ increase. The bicarbonate buffering capacity of most retort waters is substantial, and much of the lime would be required to precipitate the bicarbonate as calcium carbonate to provide free alkalinity $\left(\mathrm{OH}^{-}\right)$for increasing the pH. Ammonia stills or steam strippers used for coking liquors are operated in two segments which allows free ammonia and carbon dioxide to be removed in the first segment prior to adding lime to remove fixed ammonia $\left(\mathrm{NH}_{4}^{+}\right)$in the second segment.

The presence of bicarbonate/carbonate is not a significant barrier to the removal and recovery of ammonia by steam stripping without caustic addition. Both ammonia and carbon dioxide can be readily removed in a properly designed steam stripper. Two steam stripping processes are now used in nitrogen fertilizer plants for steam stripping ammonia and carbon dioxide (from bicarbonates) from wastewaters. One stripping process is used to treat ammonia synthes is plant process condensate typically containing $1000 \mathrm{mg} / 1$ ammonia ion in the bicarbonate form (Finneran and Whelchel 1970). The ammonia is steam-stripped down to about $20 \mathrm{mg} / 1$ and the stripper bottoms are used as feed to the demineralizer for boiler water makeup.

The other process involves steam stripping at elevated pressure (150 psig) and temperature (Mavrovic 1974) (360 to $366^{\circ} \mathrm{F}$ in the stripper bottom). For comparison, conventional strippers operate at $50 \mathrm{psig}$ with bottom temperatures in the range of 295 to $298^{\circ} \mathrm{F}$. In addition to steam, both air and carbon dioxide are injected into this high pressure steam stripping system. The process is reported to reduce ammonia from $150,000 \mathrm{ppm}$ to $20 \mathrm{ppm}$.

Air Stripping

Ammonia can also be removed by air stripping under suitable conditions such as elevated $\mathrm{pH}$ and temperature. An advanced municipal waste treatment plant for the Upper Occoquan Sewage Authority in the State of Virginia is planning to use a unique air stripping and absorption process for removing ammonia from spent ion exchange regenerant (Suhr and Kepple 1975). Ammonia is air stripped from the spent regenerant in a stripping tower and the air/ammonia mixture exiting the tower is routed to an absorption tower where the ammonia vapor is absorbed in a sulfuric acid-ammonium sulfate solution. The air from 
the absorption tower is recycled back through the stripping tower. The ammonium sulfate produced has a wholesale value greater than the cost of the sulfuric acid consumed which would partly offset the cost of the removal process. The ammonia in the spent regenerant is reduced from about $250 \mathrm{mg} / 1$ to $50 \mathrm{mg} / 1$. The process operates at a pH of about 9.5 to 11 in the stripping tower and would not be expected to remove substantial amounts of carbon dioxide.

It is possible to remove carbon dioxide in addition to ammonia by air stripping as demonstrated in laboratory studies conducted at the University of Colorado (Linstedt et al. 1976). These laboratory studies were performed using simulated shale oil retort water and nitrogen gas rather than air for stripping. The differences in removal efficiency between air and nitrogen stripping would probably not be significant. Temperature was a significant factor in the removal of ammonia by nitrogen stripping. Essentially no ammonia was stripped in batch studies until the temperature exceeded $50^{\circ} \mathrm{C}$. Ion Exchange

Ion exchange has proven effective for removing ammonia from municipal wastewaters (Suhr and Kepple 1975; Mercer et a1. 1970); however, the ammonia levels have been substantially lower than those found in shale oil retort water. Ion exchange is particularly useful for separating and concentrating small concentrations of ions. Harding et a1. (1979) reported on an investigation of ion exchange for removing ammonia from retort water with weak acid resins. They found that the high total electrolyte concentrations found in most retort waters makes ion exchange treatment of these waters impractical.

\section{BIOLOGICAL TREATMENT}

Biological treatment of petroleum refinery wastewaters is widely practiced and is included as a process for best practicable control technology currently available for end-of-the-discharge pipe treatment. Several biological treatment methods could be used to treat retort waters that have been pretreated for oil, suspended solids, and ammonium bicarbonate/carbonate removal. These methods include: activated sludge, trickling filter, anaerobic digestion, oxidation ponds, and aerated lagoons. 
Activated Sludge

In the activated sludge process, wastewater containing organic matter is fed to the aerobic reactor (aeration tank) which furnishes: 1) air required by microorganisms to biochemically oxidize the waste organics and 2) mixing to ensure close contact of microorganisms with the organic waste. The contents of the reactor are referred to as mixed liquor (i.e., wastewater activated sludge). In the vigorously mixed aerobic reactor, the organic wastes are metabolized to provide energy and growth factors for the production of more microorganisms with the release of carbon dioxide, heat, and water as metabolic end products. The organic waste compounds are thus degraded to innocuous end products and microorganisms (i.e., sludge).

The mixed liquor suspended solids (MLSS) flow from the aeration tank to a sedimentation tank, which provides quiescent settling to allow separation of the biological solids from the treated wastewater. The treated and clarified water is collected and discharged as process effluent. Most of the settled biological solids are recycled as return activated sludge back to the aerobic reactor. Recycling provides an activated mass of microorganisms for continuous treatment of incoming wastewater. Some of the settled biological solids are wasted to maintain a proper balance in the population of microorganisms in the mixed liquor suspended solids of the derobic reactor. Recycling and wasting of biological solids (microorganisms) from the reactor ensures a proper ratio of incoming waste to the population of microorganisms (food to microorganisms, or $F / M$ ratio), which is critical to efficient biodegradation of soluble organic waste compounds. The term BOD is used in this method to measure the strength of organics in wastewater and, as such, is a measure of the substrate level or food value of wastewater.

In the activated sludge process, the exact mass of microorganisms is difficult to determine. However, because of the simplicity of the test procedures involved, the standard practice is to assume that the weight of mixed liquor volatile suspended solids (MLVSS) approximates the mass of viable microorganisms present in the system. The $F / M$ ratio or process loading factor is thereby defined as: 
$\frac{1 \mathrm{~b} / \mathrm{BOD} / \mathrm{Day}}{\mathrm{Tb} \text { MLVSS }}$

This process loading factor is used extensively in current wastewater treatment practices. However, there is another parameter that is of ten used to design aeration systems. The concept of BOD loading in terms of MLVSS is extremely important, but it should be used in conjunction with knowledge of requirements and the ability of facilities to handle the system solids. For this reason, it is common practice to also base design considerations of volumetric loadings, i.e., pounds of BOD per 1000 cubic feet of aeration tank. Used together, these two parameters act to "cross-check" loading factors to ensure that the activated sludge system will operate effectively. These measures may not be adequate for retort wastewater because of its unusual nature.

The activated sludge process is very flexible and can be utilized for the treatment of a lmost any type of biodegradable waste. The original process configuration is called the conventional activated sludge process, and has been modified in numerous ways. Examples include: 1) the tapered aeration process which has greater air addition near the influent zone where the oxygen demand is the greatest; 2) step aeration which introduces waste at several points along the length of the aeration tank to distribute the oxygen demand even ly; 3) contact stabilization where return sludge is aerated separately from the wastewter to minimize the size of the aeration tanks; and 4) completely mixed activated sludge process where large mechanical mixers thoroughly mix the contents of the aeration tank, to uniformly distribute the waste load and decrease the possibility of process upsets due to shock loadings.

The activated sludge process is capable of achieving very low concentrations of BOD, COD, TSS, and oil depending on the characteristics of the raw refinery waste feed. BOD removals of 90 to $99 \%$ have been reported (U.S. EPA 1974). 


\section{Trickling Filters}

The trickling filter process consists of a fixed bed of coarse material over which wastewater is intermittently or continuously distributed in a uniform manner by a flow distributor. Microorganisms grow on the surface of the filter media forming a biological or zoogleal slime layer. Wastewater flows downward through the filter, passing over the layer for utilization by the microbial population. Oxidized end products are released to the liquid and collected in the underdrain system for discharge via the effluent channel. Aerobic conditions are maintained by air passing through the filter bed induced by the difference in specific weights of air on the inside and outside of the bed. A trickling filter will operate properly as long as the void spaces are not clogged by solids or excessive growth of the zoogleal $\mathrm{film}$ layer. The zoogleal $\mathrm{film}$ layer grows and gradually increases in thickness to the point that hydraulic shear force from the downward flow of wastewater causes portions of the film layer to slough off the filter media. These solids are subsequently separated as sludge in secondary clarification units.

The trickling filter system can be used for complete treatment, but for most applications in the petroleum industry it is used as a roughing device to reduce the load on an activated sludge plant. Because of the potentially high BOD levels in retort wastewater, it is anticipated that trickling filters could serve as roughing filters prior to another biological treatment process. Oxidation Ponds

"0xidation ponds" utilize algae and bacteria in a symbiotic relationship to stabilize waste organics. The oxygen released by the algae through photosynthes is is used by bacteria in the aerobic degradation of organic matter. The nutrients and carbon dioxide released via respiration are, in turn, used by the algae. During the daylight hours of increased algal photosynthetic activity, oxygen concentrations can reach supersaturation levels. Generally, solids will accumulate and settle in an oxidation pond because mixing is not occurring. These settled solids accumulate, forming an anaerobic sludge layer 
on the bottom, and the pond becomes an aerobic/anaerobic (facultative) pond. 0xidation ponds generally are relatively shallow ( 3 to $5 \mathrm{ft}$ deep).

Oxidation ponds are generally used where land is plentiful and inexpensive. Retention time in the ponds typically ranges from 11 to 110 days. Oxidation ponds are usually used as the principal biological treatment process, al though some petroleum refineries use the ponds as a polishing step after other forms of treatment (U.S. EPA 1974).

\section{Aerated Lagoons}

Aerated lagoons are an outgrowth of the development of the completely mixed activated sludge process in that surface mechanical aerators were applied to overloaded oxidation ponds. Aerated lagoons are generally constructed at depths of 8 to $15 \mathrm{ft}$. Generally no consideration is given to algae for supplying dissolved oxygen because the pond surface is turbulent, inhibiting the growth of algae. The additional oxygen supplied by the aerators allows a higher concentration of microbes than the oxidation pond. Retention time in these lagoons is generally 3 to 10 days. Most aerated lagoons operate without final clarification. Therefore, high BOD and suspended solids are of ten discharged as a result of the turbulence caused by the aerators. Final clarification may become a requirement for aerated lagoons to conform to more stringent regulatory standards.

Anaerobic Digestion

The anaerobic digestion process employs microorganisms which decompose certain types of organic substances without using molecular oxygen. Decomposition is accomplished by two groups of bacteria. One group of bacteria, called the "acid formers," carry out the first step in the process which is the conversion of complex organics into simple organic acids such as acetic and propionic acids. The other group of bacteria, called the "methane formers," convert the organic acids to methane and carbon dioxide in the second step of the process. The two groups of bacteria must operate in a state of dynamic equilibrium to effectively stabilize an organic waste. 
Excessive production of organic acids, for example, may reduce the $\mathrm{pH}$ below the optimal range of 6.6 to 7.6 and render the methane formers inoperative. Anaerobic digestors are generally operated at either one of two temperature ranges: mesophilic $\left(32\right.$ to $38^{\circ} \mathrm{C}$ ) and thermophilic $\left(49\right.$ to $56^{\circ} \mathrm{C}$ ).

The principal advantages of anaerobic digestion include: 1) low sludge production which minimizes the typically high cost of sludge disposal and 2) the production of methane gas as a useful byproduct. The major disadvantage is operational control which is generally more difficult than for an aerobic process. The growth rate of the methane formers is slow, and relatively long time periods are required to establish steady state.

Only a limited amount of information has been reported on biological treatment of retort water. Experimental studies conducted at the University of Southern California in the period 1975-1977 under the direction of $T$. F. Yen indicated only partial removal of $\mathrm{COD}$ and TOC from retort water generated by 10 - and 150-ton retorts at the Laramie Energy Technology Center (LETC) at Laramie, Wyoming. Methane production by anaerobic digestion was achieved in these studies but toxicity problems developed during the course of the experiments. Ossio et a1. (1978) reported results of anaerobic digestion studies conducted at the Lawrence Berkeley Laboratory of the University of California on LETC 150-ton retort water which showed 76 to $80 \%$ removal of BOD and COD. Additional studies conducted at the Lawrence Berkeley Laboratory by J. P. Fox indicate that hydraulic detention times in the anaerobic digesters would be too long for practical application of this process to the retort water studied.

\section{CARBON ADSORPTION}

The results of laboratory experiments by Hubbard (1971) revealed that essentially all the soluble organics in retort water samples used in his studies could be removed by sorption on activated carbon. A very limited amount of retort water was put through the carbon column; therefore, the method would be quite costly. Experimental column results obtained by Lindstedt et a1. (1976) showed COD and TOC removals of 74 and $72 \%$, 
respectively, after a $17-\mathrm{hr}$ run with a theoretical residence time of $57.5 \mathrm{~min}$ in the activated carbon columns. The quality of the effluent was deteriorating steadily throughout the experimental run. It was hypothesized that oily suspended matter was coating the carbon granules, thereby reducing their sorptive capacity. This hypothes is was supported by a rapidly increasing head loss throughout the run. The authors concluded that carbon sorption merits further consideration in the treatment of shale $0 i 1$ retort water.

The high organic content of the retort water will cause rapid loading of the activated carbon, thus the process could be quite costly compared to biological methods. Activated carbon is usually regenerated thermally in multiple hearth furnaces which have high energy requirements. If excess combustible retort gas is available, it might substantially reduce the cost of carbon regeneration.

Activated carbon preferentially sorbs large organic molecules that are nonpolar. It removes specific organic and inorganic material from water by the process of adsorption, which is the attraction and accumulation of one substance onto the surface of another. In general, high surface area and pore structure are the prime considerations in adsorption of material from water. The chemical nature of the carbon surface is of relatively minor significance.

Adsorption from wastewater onto activated carbon can occur as a result of two separate properties of the wastewater/activated carbon system, or some combination of the two: 1) the low solubility of a particular solute in the wastewater and 2) a high affinity of a particular solute in the wastewater for the activated carbon. According to the most generally accepted concepts of adsorption, the second surface phenomenon may be predominantly one of electrical attraction of the solute to the carbon, of van der Waals attraction, or of a chemical nature.

There are essentially three consecutive steps in the adsorption of dissolved materials in wastewater by activated carbon. The first step is the transport of the solute through a surface film to the exterior of the carbon. 
The second step is the diffusion of the solute within the pores of the activated carbon. The third step is adsorption of the solute on the interior surfaces bounding the pore and capillary spaces of the activated carbon.

Several factors can influence adsorption by activated carbon, such as: 1) the nature of the carbon itself;2) the nature of the material to be sorbed, including its molecular size and polarity; 3) the nature of the solution, including its $\mathrm{pH}$; and 4 ) the contacting system and its mode of operation.

Much of the surface area available for adsorption by carbon is found in pores created with in the carbon particles during the activation process. The major contribution to surface area is located in pores of molecular dimensions. A molecule will not readily penetrate into a pore smaller than a certain critical diameter and will be excluded from pores smaller than this diameter. The most tenacious adsorption takes place when the pores are just large enough to admit the adsorbing molecules. The smaller the pores with respect to the molecules, the greater the forces of attraction. Activated carbon is considered to be a nonpolar sorbent and tends to adsorb the least polar and least soluble organic compounds; it will adsorb most, but not all, organic compounds. Activated carbon commonly carries a net negative surface charge which is believed to be of significance in adsorption.

Activated carbon is commonly used in granular form packed in columns for wastewater treatment. It may also be used in powdered form on a batch bas is. There is, however, a lack of full-scale regeneration experience on powdered carbon.

POWDERED CARBON ADDITION TO ACTIVATED SLUDGE

Another method of gaining benefits from the use of powdered carbon is the addition of carbon directly to the mixed liquor in an activated sludge plant aeration basin (ICI America 1972). The benefits attributed to this system are (Robertaccio et a1. 1972): 
- improved $B O D$ and COD removal by adsorption and improved settling even at lower than optimal temperatures, at lower MLVSS and/or at higher than design flow rates

- adsorption of color and toxic agents that cannot be removed by merely expanding a plant

- reduction of aerator and effluent foam by adsorption of detergents

- more uniform plant operation and plant effluent quality during periods of widely varying organic and hydraulic loads

- improved solids settling (lower sludge-volume index, increased sludge solids, and lower effluent solids)

- increased aerobic digester capacity through foam reduction. The mechanisms which account for these benefits are postulated to be as follows:

- adsorption on the extensive surface area of the carbon

- biological adsorption and degradation. The carbon settles in the sludge with pollutants adsorbed, and the pollutants thus remain in the system rather than escaping in the effluent. The longer the sludge ages, the greater the chance for bio-oxidation of poorly degraded organics.

- continuous regeneration of the carbon by biological action. While the carbon and microorganisms are adsorbing organic pollutants, the microorganisms continuously degrade the pollutants, thereby freeing carbon surface areas again for sorption of more pollutants.

- improved solids settling. Improved settling in the secondary clarifier leads to lower suspended solids and BOD in the effluent. The settling rate of some powdered carbons plus biosolids is greater than that for biosolids alone. 
There is little capital investment, with the chief cost being the carbon itself. Costs of 2 to 7 cents per 1000 gallons are reported for the powdered activated carbon addition to an existing activated sludge plant. Such a process may be very attractive for the treatment of waters from shale oil development since it can offer effective biological treatment in the presence of potentially toxic substances which might otherwise inhibit growth. Pilot studies on powdered activated carbon enhancement of activated sludge treatment of refinery wastewaters indicate this approach will be more cost effective than granular carbon adsorption for all but the very highest effluent quality (Grieves et al. 1978). 


\section{TREATABILITY STUDIES}

Bench-scale treatability studies were conducted on actual and simulated in situ retort water to evaluate the effectiveness of conventional physical/ chemical and biological processes for removal of pollutants. The objective of treatment is to produce an effluent suitable for either limited or multipurpose reuse or for discharge to either surface or subsurface receiving waters.

\section{SUSPENDED SOLIDS REMOVAL}

Two methods were studied for suspended solids removal: gravity sedimentation and chemical coagulation/flocculation.

Gravity Sedimentation of Raw Retort Water

Samples of Geokinetics in situ retort water taken from a holding basin were inspected for settleable and floatable matter. The holding basin receives retort water from a tank used to separate the water from the retorted shale oil. The samples were shipped in 55-gal steel drums and were in transit for about 2 weeks at ambient summertime temperatures. A very thin $f i l m$ of $0 i 1$ was evident on top of the retort water in the drums prior to mixing and sampling for analysis; however, there was no visible difference between samples of mixed and unmixed retort water.

Neither settleable nor floatable matter was observed after a 2-hr settling period. The lack of this material in these samples may not be indicative of what might be expected in a full-scale facility because of differences in the separator hydraulic residence times. Furthermore, the use of fresh samples of retort water for gravity sedimentation tests is believed necessary to assure that the test results would be applicable for engineering design work on a treatment plant. Storage of the horizontal in situ retort water at $4^{\circ} \mathrm{C}$ is not sufficient to prevent changes in the physical appearance of this water from occurring over a period of several days. Precipitates of darkcolored substances have been observed to form after storage in glass bottles for 3 days at $4^{\circ} \mathrm{C}$. 


\section{Chemical Coagulation and Flocculation}

Only a limited number of chemical coagulation and flocculation tests were conducted on the retort water received at PNL because it is believed that comprehensive testing of this type should be conducted on fresh samples of retort water to assure reliable results. Retort water for these tests was obtained from the separator rather than the holding basin to include a greater amount of 0 il in the retort water. The samples were taken near the oil/water interface so these samples may not be entirely representative. Nevertheless some oil was included in the wastewater to observe how it would separate in the coagulation/flocculation tests.

Jar tests were conducted with $400 \mathrm{ml}$ of well-mixed retort water in oneliter beakers. Chemical coagulants and flocculants were added to the retort water and rapid mixing was carried out with paddle type stirrers for 3 min at 100 RPM. Rapid mixing was followed by a 15-min flocculation period with the stirrers set at $40 \mathrm{RPM}$. The mixtures were then allowed to settle for $10 \mathrm{~min}$ or 30 min periods before sample aliquots were removed for suspended solids determinations. Table 10 presents results of the jar tests using polymers only. The results indicate that the cationic polymer may be superior to the neutral and ionic polymers although considerably more testing on fresh retort water would be required to verify this observation and establish an optimal dosage.

TABLE 10. Effect of Polymer Type and Dosage on Removal of Suspended Solids from Retort Water $(a)$

Suspended Solids

\begin{tabular}{|c|c|c|}
\hline Polymer Type & Dosage, $\mathrm{mg} / \mathrm{l}$ & After 10 min sett 1 ing, $\mathrm{mg} / 1$ \\
\hline Anionic & 1.25 & 196 \\
\hline Anionic & 2.50 & 225 \\
\hline Anionic & 5.00 & 220 \\
\hline Neutral & 2.50 & 185 \\
\hline Neutral & 5.00 & 218 \\
\hline Cationic & 5.00 & 137 \\
\hline Bl ank & 0 & 237 \\
\hline
\end{tabular}

(a) Geokinetics retort water aged approximately 2 weeks at ambient summertime temperatures. 
The results of alum coagulation tests on Geokinetics retort water with suspended shale oil are presented in Table 11. Although the suspended solids results indicate some separation of suspended matter, none of the alum dosages produced a clarified liquor. These and other tests indicate a highly stable emulsion which is difficult to break without a pH change to the acid side. This $\mathrm{pH}$ change requires a rather costly acid addition because of the typically high alkalinity concentration in retort water. The lower alum dosages would appear to be useful for dissolved air flotation since the suspended matter tends to float with the alum floc.

TABLE 11. Alum Coagulation of Geokinetics Retort Water

\begin{tabular}{|c|c|c|c|}
\hline \multirow[b]{2}{*}{ Alum Dos age } & \multicolumn{3}{|c|}{ Suspended Solids, mg/l } \\
\hline & $\begin{array}{l}\text { After } 10 \mathrm{~min} \\
\text { Settling } \\
\end{array}$ & $\begin{array}{l}\text { After } 30 \mathrm{~min} \\
\text { Settling } \\
\end{array}$ & Observations \\
\hline 0 & 199 & 159 & Appears homogeneous \\
\hline 50 & 132 & 94 & Floating matter \\
\hline 100 & 160 & 96 & Floating matter \\
\hline 250 & 191 & 99 & $\begin{array}{l}\text { Floating and } \\
\text { settled matter }\end{array}$ \\
\hline 500 & 127 & 92 & $\begin{array}{l}\text { Suspended and } \\
\text { settled matter }\end{array}$ \\
\hline 1000 & 69 & 81 & Settled matter only \\
\hline
\end{tabular}

STEAM STRIPPING

Steam stripping can be considered a form of gas stripping where water vapor at elevated temperature is used as the medium for transfer and removal of volatile constituents from a liquid. Steam stripping is generally carried out in a continuous operation with a tower equipped with trays (e.g., bubble cap or sieve) or a suitable packing (e.g., saddles or rings) which enhances the contact of the gaseous phase with the liquid phase. 


\section{Process Description}

A typical steam stripper design is illustrated in Figure 4. The preheated feed from the heat exchange is introduced at the top of the tower and flows by gravity counter-current to the steam, flowing up from the bottom of the tower. As the liquid flows down the tower it contacts steam containing progressively lower concentrations of volatile constituents stripped from the liquid. At the same time, the volatile constituents in the liquid are reduced to lower concentrations as the liquid flows to the bottom of the tower. The concentration of the volatile constituents is reduced to the lowest value at the bottom of the tower, where the liquid is first contacted by the incoming steam. Heat conservation is practiced by preheating the feed with the stripped bottoms in a heat exchanger.

Steam from the top of the tower may either be condensed or it may be further processed in the gaseous phase (e.g., incinerated) before discharge. Condensation of the steam and organic vapors may produce an aqueous phase and an organic phase (e.g., water immiscible organics) which can be separated by

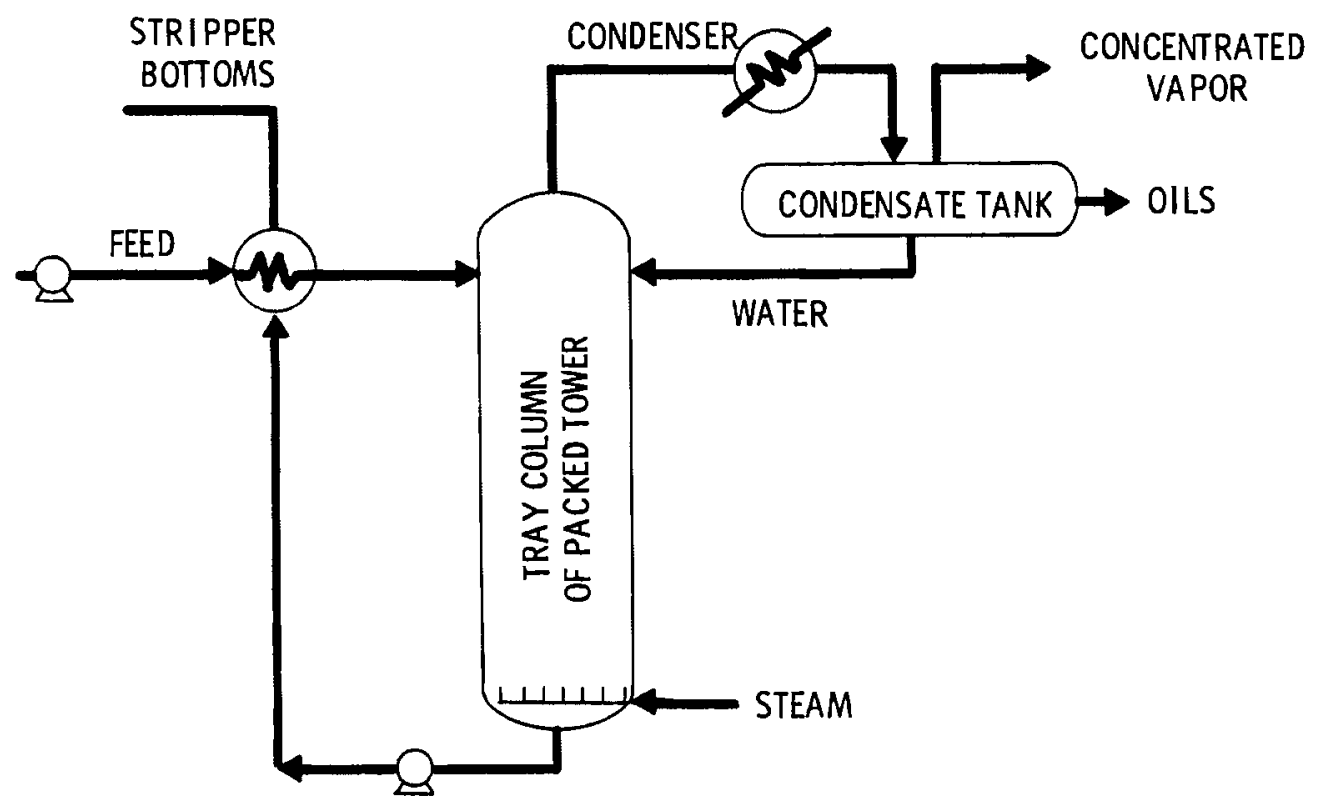

FIGURE 4. Typical Steam Stripping System 
decantation. Noncondensable vapor and gases may receive further treatment or release to the atmosphere if pollutant levels are low. Recycle or reflux of the condensate stream to the tower serves to increase the concentration of volatile constituents in the effluent steam from the tower and also eliminates a secondary wastewater stream which might require treatment before release.

Removal of volatile matter by a stripping tower may be increased by increasing the number of vapor/liquid contact stages in the tower. For example, the height of the tower can be increased to include additional trays or packing to increase the number of stages. Alternatively, a more effective packing may be substituted for the existing packing in the tower to increase the number of stages without altering the dimensions of the tower.

Steam stripper efficiency is not only a function of the number of vapor/ liquid contact stages but also temperature, steam/liquid ratios, and, in the case of the volatile acids and bases, the $\mathrm{pH}$ of the liquid. The effect of steam-to-feed ratio and number of stages on ammonia removal from petroleum refinery sour water is illustrated in Figure 5. These data show that less stripping steam is needed as the number of stages is increased, but the potential for further steam savings diminishes. The terminology "theoretical stage" is used to denote the segment of a tower needed to achieve a liquid equilibrium concentration that corresponds to the vapor phase at a given zone in the tower. Although this concentration cannot actually be attained, in practice equilibrium can be approached so closely that the difference is unimportant. Several trays may be needed to achieve liquid equilibrium concentrations corresponding to the vapor concentrations entering the lower tray of a sequence of trays in the tower. Theoretical stages are used in computational methods to describe the performance of a steam stripper under a variety of operating conditions.

Temperature of the feed to the tower is important to maintaining good stripper performance. Introduction of a cold feed stream to the tower results in substantial condensation of steam in the upper portion of the tower and therefore requires a greater steam input to maintain an outflow of steam from the tower. 


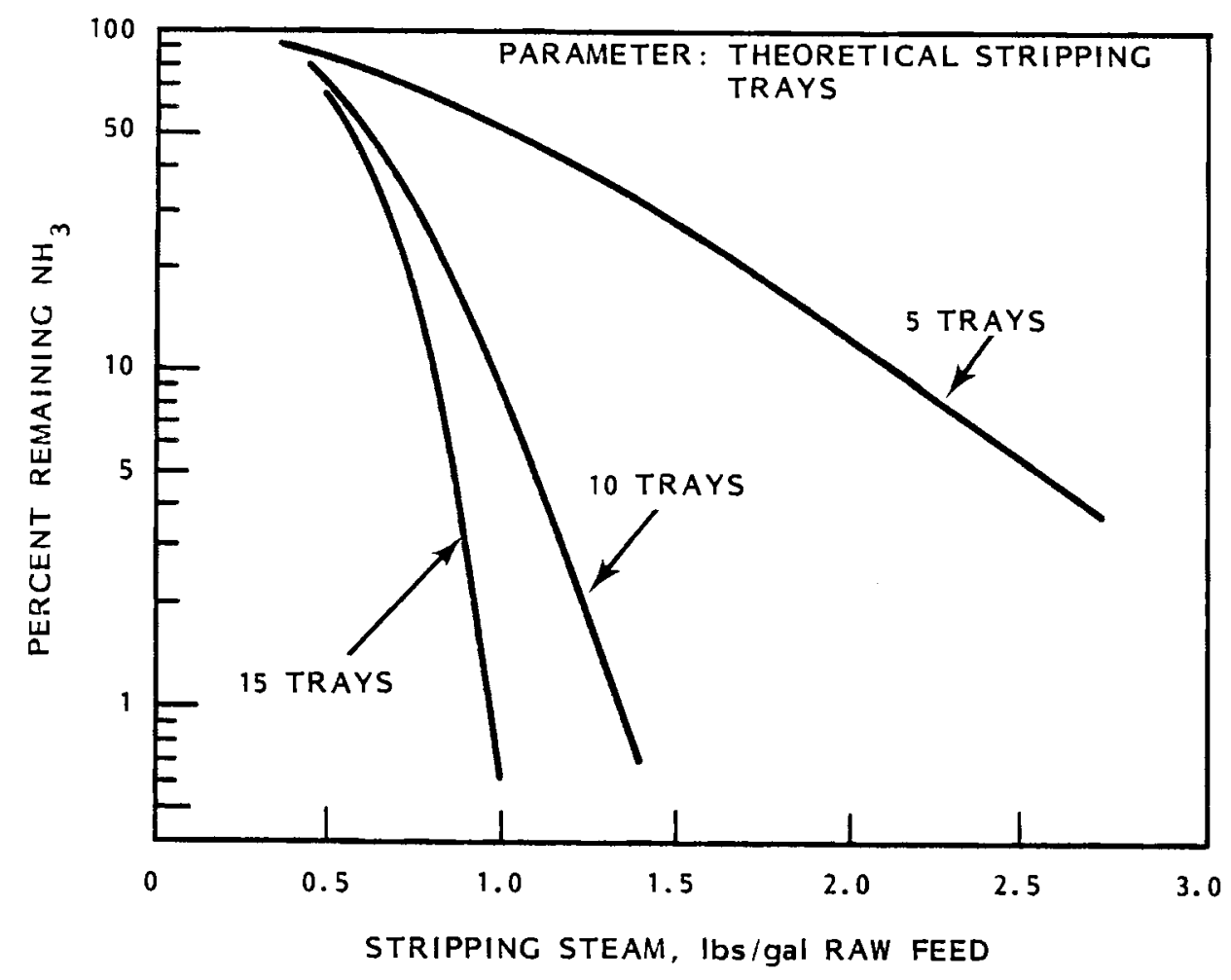

FIGURE 5. Effect of Steam-to-Feed Ratio and Number of Stages on Ammonia Removal (Melin et a1. 1975)

\section{Report Water Stripping}

Applications of steam stripping to shale oil process water would be primarily for the purpose of removing ammonia, although other volatile constituents such as carbon dioxide and light organics will also be removed. Effective removal of ammonia by steam stripping requires sufficient alkalinity in the wastewater to convert the ammonia to the gaseous form which is volatile. Ammonia is generally found at relatively high concentrations in shale oil process waters in combination with carbon dioxide (e.g., armonium bicarbonate). In pure aqueous solutions of ammonia and carbon dioxide, the following equilibrium exists:

$$
\mathrm{NH}_{3}+\mathrm{CO}_{2}+\mathrm{H}_{2} \mathrm{O}=\mathrm{NH}_{4}^{+}+\mathrm{HCO}_{3}^{-}
$$




$$
\begin{aligned}
& \mathrm{NH}_{3}+\mathrm{HCO}_{3}^{-}=\mathrm{NH}_{2} \mathrm{COO}^{-}+\mathrm{H}_{2} \mathrm{O} \\
& \mathrm{NH}_{3}+\mathrm{HCO}_{3}^{-}=\mathrm{NH}_{4}^{+}+\mathrm{CO}_{3}^{=}
\end{aligned}
$$

The composition of aqueous solutions of $\mathrm{NH}_{3}$ and $\mathrm{CO}_{2}$ has been determined by Van Krevelen et a1. (1949) over a temperature range of 20 to $60^{\circ} \mathrm{C}$ for various $\mathrm{NH}_{3} / \mathrm{CO}_{2}$ ratios in $0.125 \mathrm{~N}$ to $2 \mathrm{~N}$ ammonia solutions. A diagram depicting the mole fraction of $\mathrm{NH}_{3}$ and dominant ionic species is presented in Figure 6 for $0.125 \mathrm{~N}$ ammonia at $20^{\circ} \mathrm{C}$. The vapor pressure for $\mathrm{NH}_{3}$ and $\mathrm{CO}_{2}$ for this same system is illustrated in Figure 7. The vapor pressure of $\mathrm{CO}_{2}$ in this system exceeds that of $\mathrm{NH}_{3}$ when the ratio $\mathrm{CO}_{2} / \mathrm{NH}_{3}$ exceeds 0.43 . Since steam stripping is normally conducted at temperatures slightly above $100^{\circ} \mathrm{C}$, the data of Van Krevelen was extrapolated to $110^{\circ} \mathrm{C} \log \mathrm{K}$ equilibrium coefficients for reactions (1), (2), and (3) versus $1 / T$. Figure 8 illustrates the mole fractions of the predominant chemical species in a $0.1 \underline{M}$ ammonia solution to which carbon dioxide is added. The carbamate and carbonate ion concentrations are relatively low in this system.

The vapor pressure of $\mathrm{NH}_{3}$ and $\mathrm{CO}_{2}$ in the system $\mathrm{NH}_{3}-\mathrm{CO}_{2}-\mathrm{H}_{2} \mathrm{O}$ at a total $\mathrm{NH}_{3}$ concentration of $0.1 \mathrm{M}$ is illustrated in Figure 9. The vapor pressure of the $\mathrm{CO}_{2}$ and $\mathrm{NH}_{3}$ are the same as a ratio, $\mathrm{R}$, of just under 0.2 for this system. A solution of ammonium bicarbonate would be expected to lose $\mathrm{CO}_{2}$ at a much more rapid rate than $\mathrm{NH}_{3}$ in a steam stripper near the feed inlet of the stripping tower. The high $\mathrm{CO}_{2}$ removal rate should continue until an $\mathrm{R}$ value is reached where $\mathrm{CO}_{2}$ and $\mathrm{NH}_{3}$ are removed at about the same rate. A stage-bystage computation of $\mathrm{NH}_{3}$ and $\mathrm{CO}_{2}$ concentrations in a stripping tower was performed using the method of Beychok (1967). This method utilizes partial pressures for $\mathrm{NH}_{3}$ and $\mathrm{CO}_{2}$ based on equilibrium data and is, therefore, valid only for a pure $\mathrm{NH}_{3}-\mathrm{CO}_{2}-\mathrm{H}_{2} \mathrm{O}$. Complex systems such as shale $0 \mathrm{il}$ process water contain other chemical species which interact with the $\mathrm{NH}_{3}$ and $\mathrm{CO}_{2}$ to affect the partial pressures associated with these gases. Table 12 shows $\mathrm{NH}_{3}$ and $\mathrm{CO}_{2}$ removal at each of six theoretical stages in a steam stripping tower receiving a 0.1 M total $\mathrm{NH}_{3}$ and $0.0667 \underline{M}$ total $\mathrm{CO}_{2}$ solution. As expected, a high $\mathrm{CO}_{2}$ removal was 


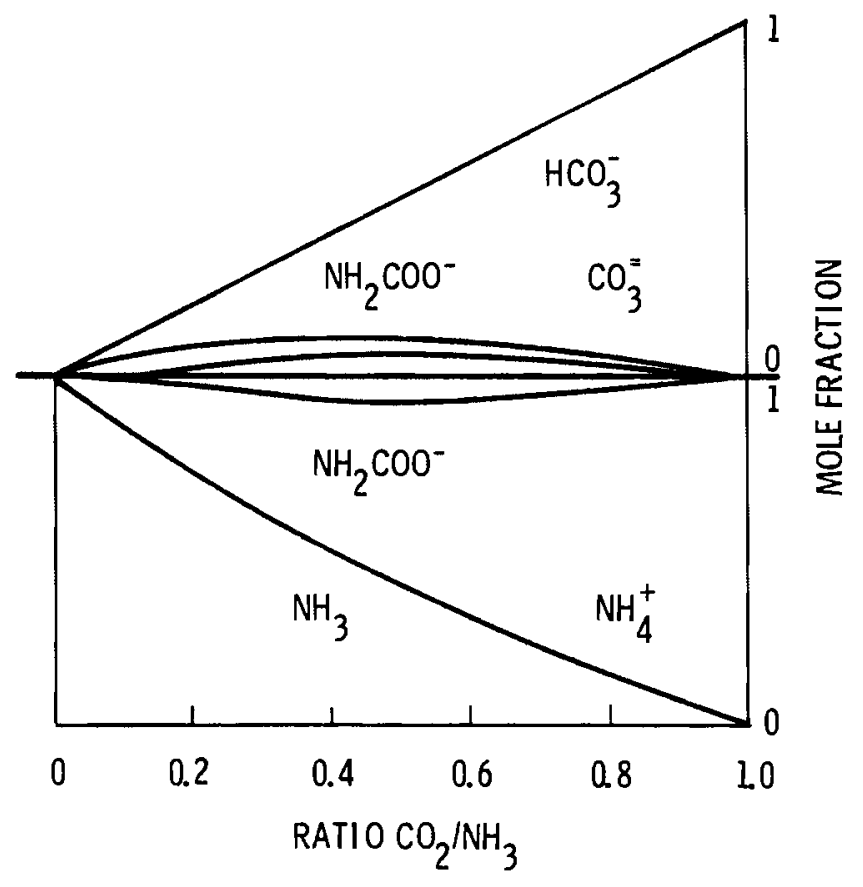

FIGURE 6. $\mathrm{NH}_{3}-\mathrm{CO}_{2}-\mathrm{H}_{2} \mathrm{O}$ System with $0.125 \mathrm{~N} \mathrm{NH}_{3}$ at $20^{\circ} \mathrm{C}$

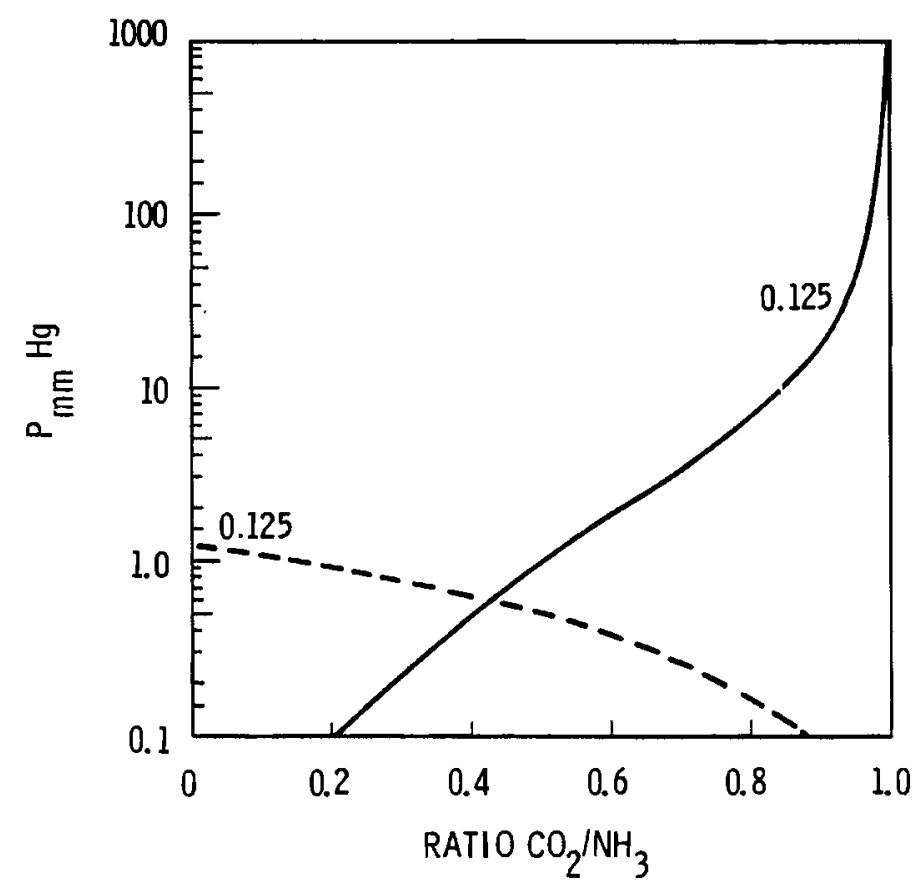

FIGURE 7. Partial Pressure of $\mathrm{NH}_{3}$ and $\mathrm{CO}_{2}$ at $20^{\circ} \mathrm{C}$ and $0.125 \mathrm{~N} \mathrm{NH}_{3}$ 


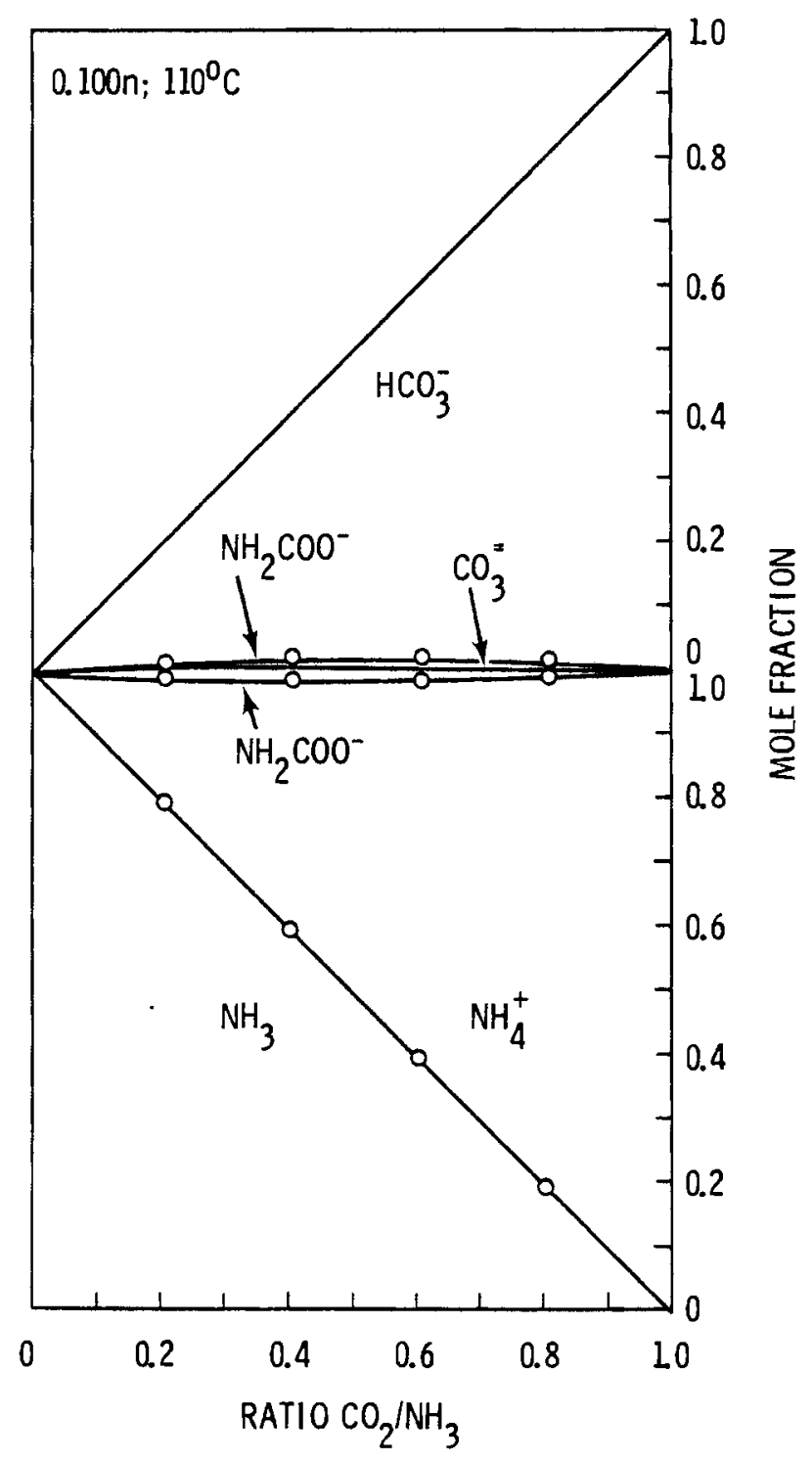

FIGURE 8. Mole Fraction of Predominant Chemical Species in $\mathrm{NH}_{3}-\mathrm{CO}_{2}-\mathrm{H}_{2} \mathrm{O}$ System at $110^{\circ} \mathrm{C}$

obtained in the first stage. The $\mathrm{CO}_{2}$ removal, in effect, increases the $\mathrm{pH}$ of the solution which both decreases the amount of free $\mathrm{CO}_{2}$ in solution and increases the amount of free $\mathrm{NH}_{3}$ in solution. 


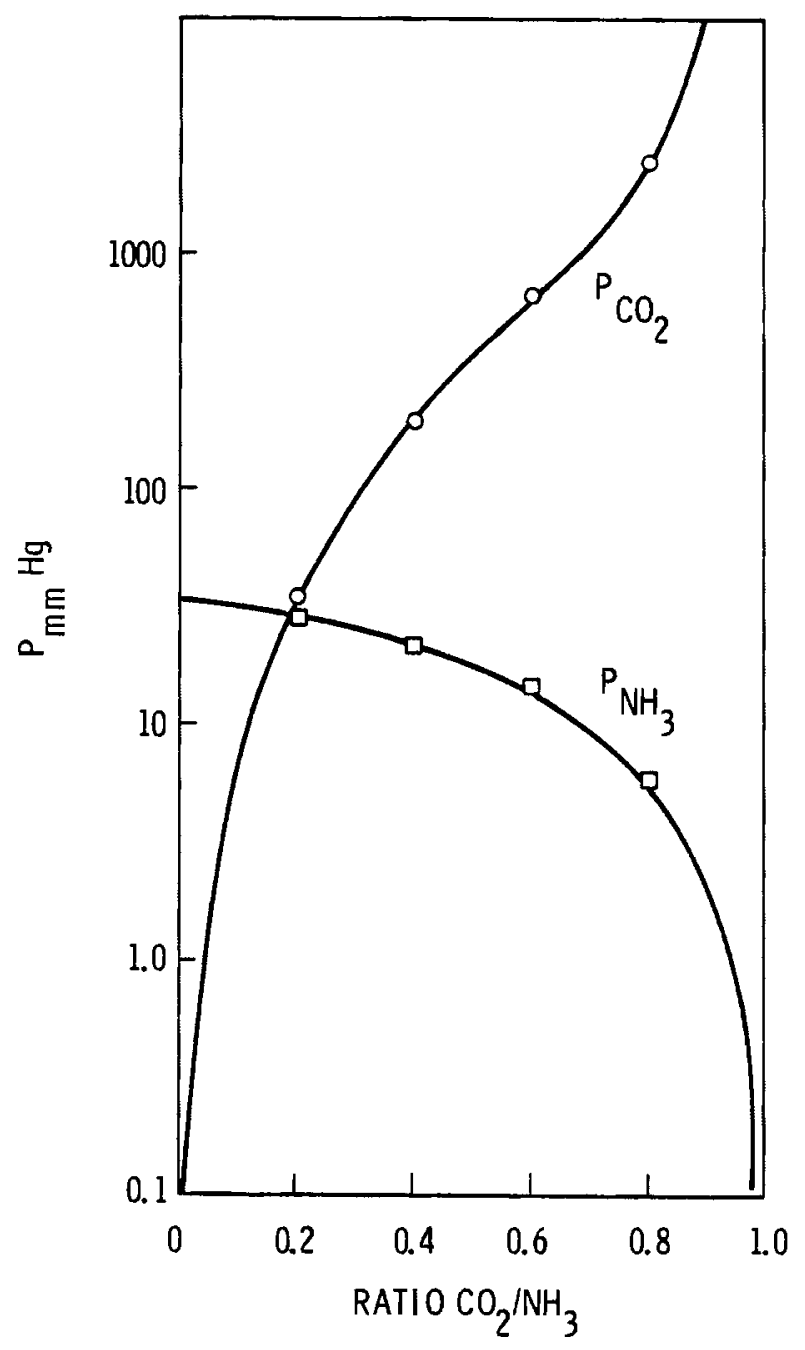

FIGURE 9. Vapor Pressure of $\mathrm{NH}_{3}$ and $\mathrm{CO}_{2}$ at $110^{\circ} \mathrm{C}$ and $0.1 \mathrm{M}$ Tota $1 \mathrm{NH}_{3}$ and Variable $\mathrm{CO}_{2}$ Concentrations

\section{Bench-Scale Studies}

Bench-scale studies were performed to evaluate steam stripping as a means of removing ammonia from retort water. The steam stripper used in this work consists of 5-cm ID glass pipe packed to a depth of $120 \mathrm{~cm}$ with either 1.27 or $0.635 \mathrm{~cm}$ Intalox ${ }^{\circledR}$ ceramic saddles. This apparatus is shown in figure 10 .

${ }^{\circledR}$ Trademark, Norton Company 
TABLE 12. Ammonia and Carbon Dioxide Removal by Theoretical Stages in a Steam Stripper Tower

\begin{tabular}{|c|c|c|c|c|}
\hline & $\begin{array}{c}\mathrm{NH}^{3} \\
\text { Concentration } \\
\mathrm{mg} / \mathrm{l} \\
\end{array}$ & $\begin{array}{c}\mathrm{NH}^{3} \\
\text { Removal } \\
\% \\
\end{array}$ & $\begin{array}{c}\mathrm{co}^{2} \\
\text { Concentration } \\
\mathrm{mg} / \mathrm{l} \\
\end{array}$ & $\begin{array}{c}C^{2} \\
\text { Removal } \\
\% \\
\end{array}$ \\
\hline Feed & 1,700 & -- & 2,935 & -- \\
\hline Stage 1 & 810 & 52 & 276 & 91 \\
\hline Stage 2 & 365 & 55 & 62.3 & 77 \\
\hline Stage 3 & 167 & 54 & 22.6 & 64 \\
\hline Stage 4 & 81 & 51 & 11.2 & 50 \\
\hline Stage 5 & 37 & 54 & 6.3 & 44 \\
\hline Stage 6 & 15 & 59 & 3.5 & 44 \\
\hline
\end{tabular}

Feed/Overhead Ratio $=6.67$ (15\% Boiloff)

Feed Composition $=0.1 \mathrm{M}$ Total Ammonia

$0.06 \overline{6} 7$ M Total Carbon Dioxide

Feed to the stripper is introduced at the top of the column of saddles and is counter-currently contacted with steam generated by a reboiler at the bottom of the column. Steam containing volatile constituents stripped from the feed is removed from the top of the column, condensed, and collected in a condensate receiver. The condensate receiver is vented to a water trap in series to absorb ammonia vapor carried over with noncondensable gases. The condensate may be recycled by injecting it into the feed stream to the stripping column. The alternative of no condensate recycle results in an aqueous ammonia solution which contains volatile organics stripped from the retort water. The steam-stripped feed collects in the reboiler and is withdrawn continuously to maintain a constant level in the reboiler.

Tests were made with several different process waters. The results are presented in Table 13. The major difference between the two runs made with simulated in situ process water is the addition of alkalinity in the case where condensate was recycled. This accounts for the higher effluent $\mathrm{pH}$ which is critical to maintaining ammonia as free $\mathrm{NH}_{3}$. Without the alkalinity 


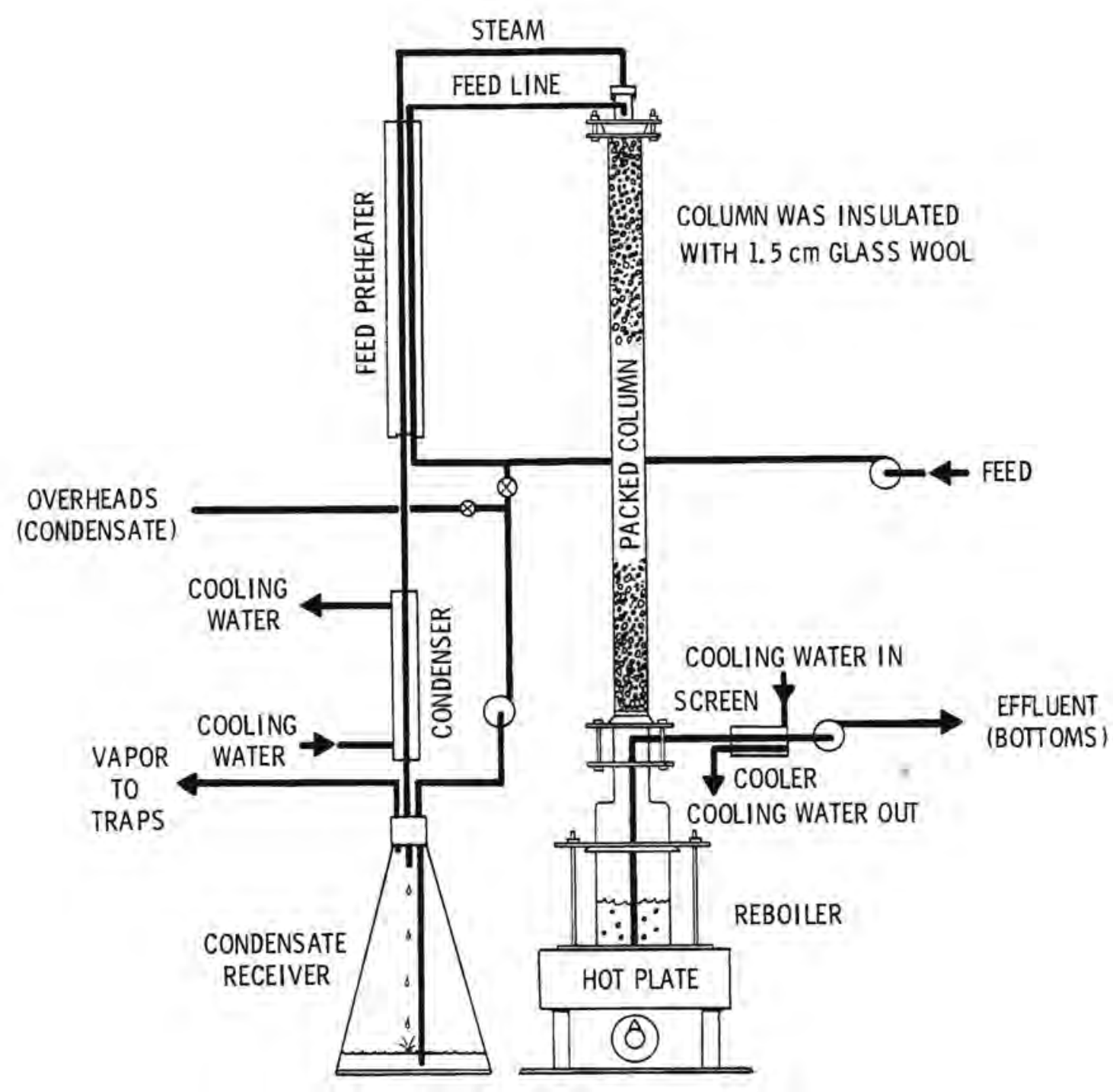

FIGURE 10. Diagram of Bench-Scale Steam Stripper

addition, the performance with recycle and lower boiloff rate would have given armonia removal levels below $98 \%$. With the alkalinity addition, it was possible to achieve $99.95 \%$ removal. The effect of alkalinity addition on steam stripping of simulated in situ process water is illustrated in Figure 11. Without the addition of $\mathrm{NaOH}$, the $\mathrm{pH}$ drops to 7.9 where some of the ammonia is in the fixed form and is not available for stripping. On the other hand, nearly all of the ammonia is available as free $\mathrm{NH}_{3}$ above $\mathrm{pH} 9.5$ and is readily stripped. 
TABLE 13. Steam Stripping Results with 2-in. Column

\begin{tabular}{|c|c|c|c|c|c|c|c|c|}
\hline Process Water & $\begin{array}{l}\text { Stripper Packing } \\
\text { Diameter, }{ }^{(a)} \mathrm{cm}\end{array}$ & $\begin{array}{c}\begin{array}{c}\text { Feed Rate, } \\
\mathrm{ml} / \mathrm{min}\end{array} \\
\end{array}$ & $\begin{array}{l}\text { Boiloff } \\
\text { Rate, } \\
\text { (b) } \%\end{array}$ & $\begin{array}{c}\text { Condensate } \\
\text { Recycle } \\
\end{array}$ & $\begin{array}{c}\begin{array}{c}\text { Feed } \\
\mathrm{pH}\end{array} \\
\end{array}$ & $\begin{array}{c}\text { Effluent } \\
\mathrm{pH}\end{array}$ & $\begin{array}{l}\text { Total Organic } \\
\text { Removal, } \% \\
\end{array}$ & $\begin{array}{c}\text { Ammonia } \\
\text { Removal, \% }\end{array}$ \\
\hline Simulated in situ & 0.64 & 55 & 14 & No & 9.4 & 7.9 & - & 98. \\
\hline Simulated in situ & 0.64 & 45 & 11 & Yes & 9.5 & 10.2 & 18 & 99.95 \\
\hline Geok inetics No. 2 & 1.28 & 100 & 8 & No & 8.8 & 9.7 & - & 99.5 \\
\hline Geokinetics No. 2 & 1.28 & 110 & 5 & Yes & 8.8 & 9.7 & - & 83 \\
\hline Geokinetics No. 3 & 0.64 & 57 & 5 & Yes & 8.7 & 9.6 & 19 & 96 \\
\hline Geok inetics No. 4 & 0.64 & 51 & 6 & Yes & 8.6 & 10.0 & 17 & 99.5 \\
\hline Paraho & 0.64 & 27 & 30 & Yes & 8.5 & 6.2 & - & 38 \\
\hline
\end{tabular}

(a) Intalox saddles.

(b) Percent of feed. 


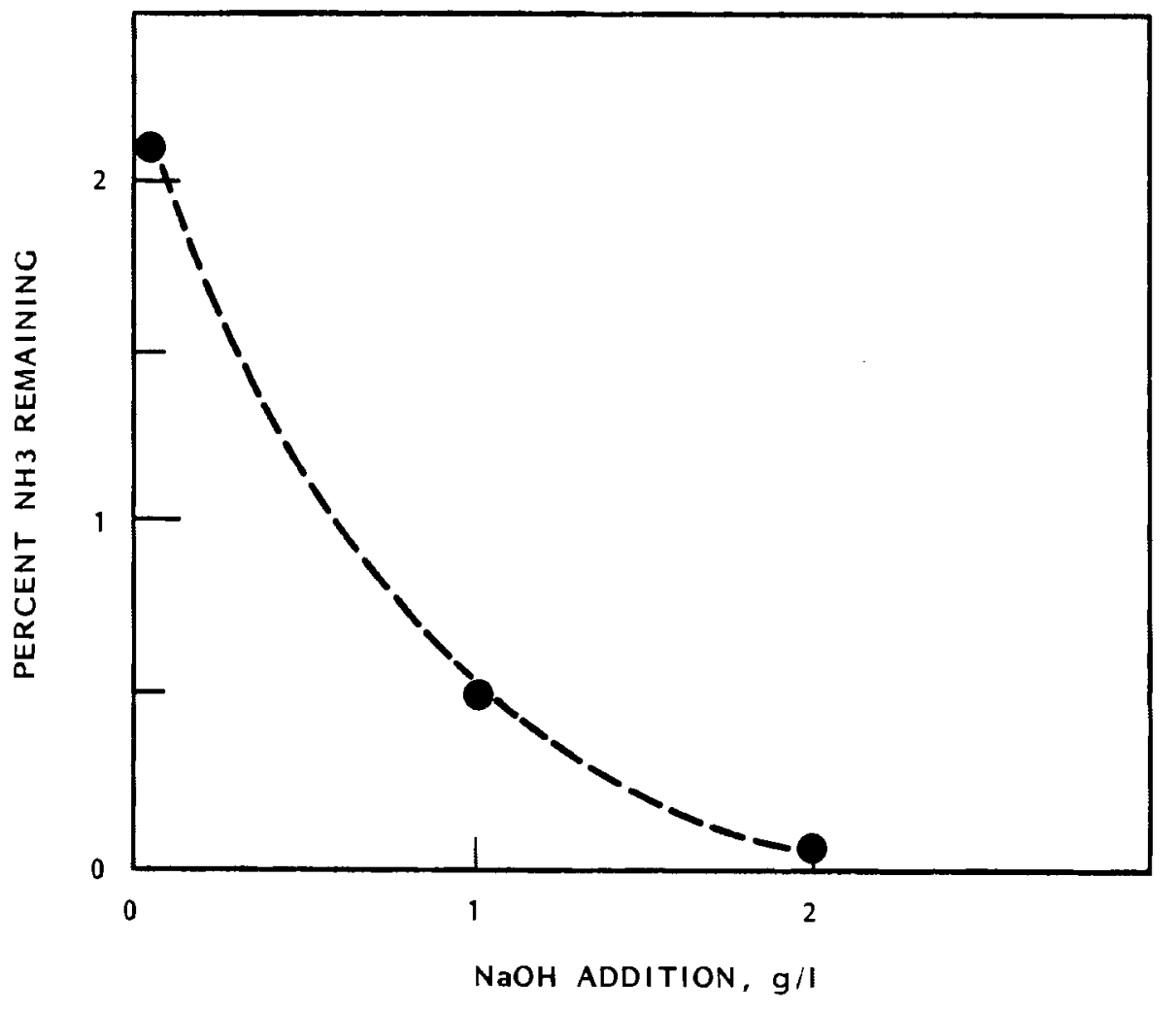

FIGURE 11. Effect of Alkalinity Addition on Armonia Removal from Simulated in situ Process Water by Steam Stripping

Stripping data in Table 13 for Geokinetics No. 2 shows the effect of recycle of the condensate at low boiloff rates. Ammonia removal was only $83 \%$ with recycle at a boiloff rate of $5 \%$. Changing the packing to a smaller size as in Geokinetics No. 3 appeared to increase the ammonia removal at a boiloff rate of $5 \%$. Additional factors which may have contributed to the higher ammonia removal rate are the lower flow rate and a different composition of process water, although the primary controlling factor of $\mathrm{pH}$ was essentially the same for each wastewater. The stripper performance for Geokinetics No. 4 was much improved over No. 3. This improvement was apparently due to small increases in the boiloff rate and $\mathrm{pH}$. The $\mathrm{pH}$ from feed to effluent increased due to the stripping of $\mathrm{CO}_{2}$ from the $\mathrm{NaHCO}_{3}$ present in Geokinetics process water. Ammonia removal for the Paraho retort water was very poor since most of the armonia is in the fixed form $\mathrm{NH}_{4}^{+}$without sufficient carbonate alkalinity. Addition of inexpensive alkalinity in the form of lime to this 
water creates a large amount of calcium carbonate sludge. The formation of this sludge can be avoided and lime usage minimized by removing the free ammonia first in a separate stripper or stripper section (which also removes $\mathrm{CO}_{2}$ ), then adding lime to remove the fixed ammonia in another stripper or section of the stripper. Removal of free and fixed ammonia is accomplished on coking liquor in this manner.

Some fouling of the packing in the stripping column was observed in the case of Geokinetics retort water, which may have been the result of suspended matter depositing on the packing. Although settled retort water was used, it contained about $150 \mathrm{mg} / 1$ of suspended solids, which was reduced to about $30 \mathrm{mg} / 1$ through the stripper. The use of trays instead of packing may be required in a full-scale steam stripper to minimize fouling problems. A small volume of light oil was also removed by the steam stripping operation. Organic carbon removal by steam stripping determined for three runs ranged from 17 to 19\%. A $70 \%$ reduction in total alkalinity was measured in one test of the stripper. Problems with foaming were experienced with the operation of the reboiler on the bench-scale steamer stripper. Maintaining a low liquid level in the reboiler or addition of an anti-foaming agent was necessary to prevent the foam from entering and flooding the column.

\section{BIOLOGICAL PROCESSES}

Bench-scale studies were conducted to evaluate both anaerobic and aerobic biological treatment of retort waters.

Anaerobic Treatment

Anaerobic digestion was evaluated on retort water from three different sources: 1) Geokinetics, 2) a simulated in situ test facility, and 3) Paraho. Bench scale units were operated as conventional, completely mixed, mesophilic (30 to $37^{\circ} \mathrm{C}$ ) digesters. Solids residence times (SRT) ranged from 15 to 50 days. Because of potential toxicity problems in the digesters, several pretreatment options were also examined, including steam stripping for ammonia removal and chemical precipitation of arsenic. In addition, the use of powdered activated carbon as a digester additive has been studied. 
Two laboratory anaerobic digesters were used in the research. Each vessel consisted of a glass reaction flask with a working volume of 3.51 . The units were completely sealed to prevent contact with atmospheric oxygen. Digester temperatures were maintained at $35 \pm 1^{\circ} \mathrm{C}$ by means of individual heating mantles and temperature controllers. Gas recirculation mixing systems attached to each unit were operated for 15 min every hour, and provided complete mixing. The gas produced in each digester was collected in a 7-1 plexiglass column by displacement of a saturated salt solution acidified to $\mathrm{pH} 3$. The columns were calibrated so that collected gas volumes could be determined based on liquid level.

The bench-scale digesters were operated on a semi-continuous feed basis; once each day substrate was withdrawn from the system and an equal volume of fresh feed subsequently added. Additions of powdered carbon or inorganic nutrients were made by incorporating these materials with the feed. During portions of the experimental runs, anaerobically digested and primary clarifier sewage sludges were added to the test vessels. These sludges were obtained from the Richland, Washington, sewage treatment plant. The primary sludge generally had a total solids content of about $3.5 \%$, of which approximately $75 \%$ consisted of volatile solids.

Effluent from the test digesters was periodically analyzed for $\mathrm{pH}$, alkalinity, COD, and total volatile acids. These analyses were conducted in accordance with the procedures specified in Standard Methods (14th Edition). Composition of the digester product gas was occasionally determined using a gas chromatograph technique.

Five tests were run. The tests and results are discussed below.

Test No. 1

In this study the feasibility of anaerobically digesting a sample of Utah in situ retort water was evaluated. Operation of digesters with and without powdered activated carbon was assessed. Initially, two experimental digesters were filled with 1,500 $\mathrm{ml}$ digested sludge and 2,000 $\mathrm{ml}$ primary sludge. One of the units received a dose of $1,500 \mathrm{mg} / 1$ carbon, and this level was maintained 
in the digester throughout the study. During the first 7 weeks of operation the units received a primary sludge feed and functioned at a 15-day SRT. Unstressed steady-state performance was achieved as evidenced by volatile acid concentrations of less than $250 \mathrm{mg} / 1$ and consistently high gas production.

At the beginning of the eighth week the feed to both digesters was modified to contain approximately $20 \%$ retort water and $80 \%$ primary sludge (1:4 feed ratio). Characteristics of the in situ retort water used in the experiment are 1 is ted in Table 14. The water was not pretreated, except for reducing the pH from 8.8 to 7.0 by the addition of concentrated hydrochloric acid. As shown in Figure 12, gas production rates in both digesters averaged about $25 \mathrm{ml} / \mathrm{hr} / 1$ during the tenth week. Based on a loading rate of $1.4 \mathrm{~kg} \mathrm{VS} / \mathrm{m}^{3} /$ day, this average corresponds to a gas conversion efficiency of $4201 / \mathrm{kg}$ VS applied. Such a rate is generally considered ind icative of a well-operating sewage sludge digestion system, with typical values ranging from 375 to $6251 / \mathrm{kg}$ VS applied. Volatile acid concentrations are plotted in Figure 13 . These values were less than $500 \mathrm{mg} / 1$ in both digesters when measured during Weeks 8 and 9 ,

TABLE 14. Analysis of Geokinetics Retort Water Used in Test No. 1

$\begin{array}{lc}\text { Total Solids, mg/l } & 14,600 \\ \text { Total Dissolved Solids, mg/l } & 14,400 \\ \text { Volatile Dissolved Solids, mg/l } & 3,200 \\ \mathrm{pH} & 8.8 \\ \text { Total Alkalinity, mg/l CaCO } & 14,300 \\ \text { Armonia, mg/l NH } 3^{-\mathrm{N}} & 3,060 \\ \mathrm{COD}, \mathrm{mg} / 1 & 8,240 \\ \mathrm{BOD}_{5}, \mathrm{mg} / 1 & 3,400 \\ \mathrm{Na}^{+}, \mathrm{mg} / 1 & 3,600 \\ \mathrm{~K}^{+}, \mathrm{mg} / 1 & 230 \\ \mathrm{Mg}^{+2}, \mathrm{mg} / 1 & 100 \\ \mathrm{Ca}^{+2}, \mathrm{mg} / 1 & 2.9\end{array}$




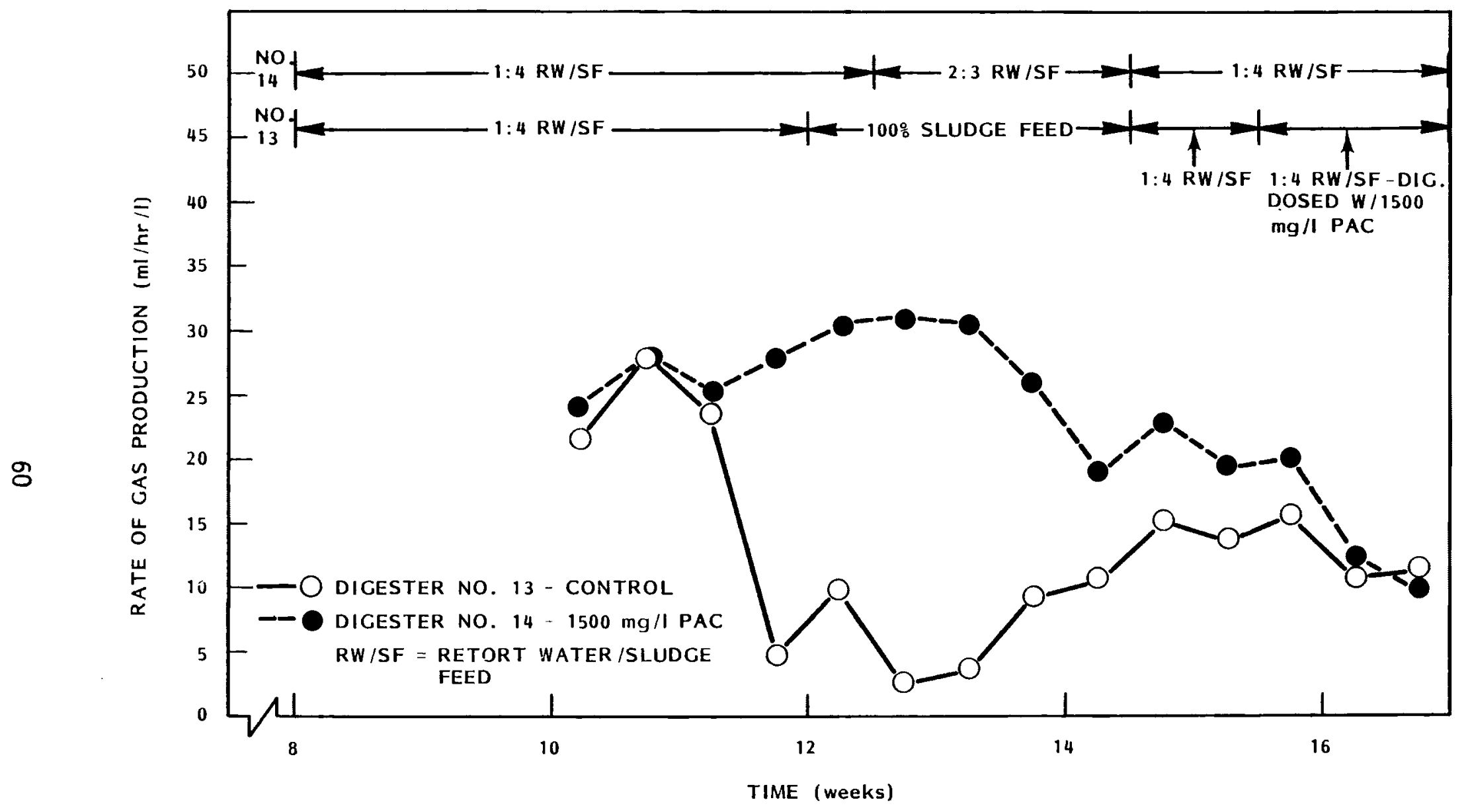

FIGURE 12. Rates of Gas Production for the Anaerobic Digestion of Geokinetcs Retort Water - Test No. 1 


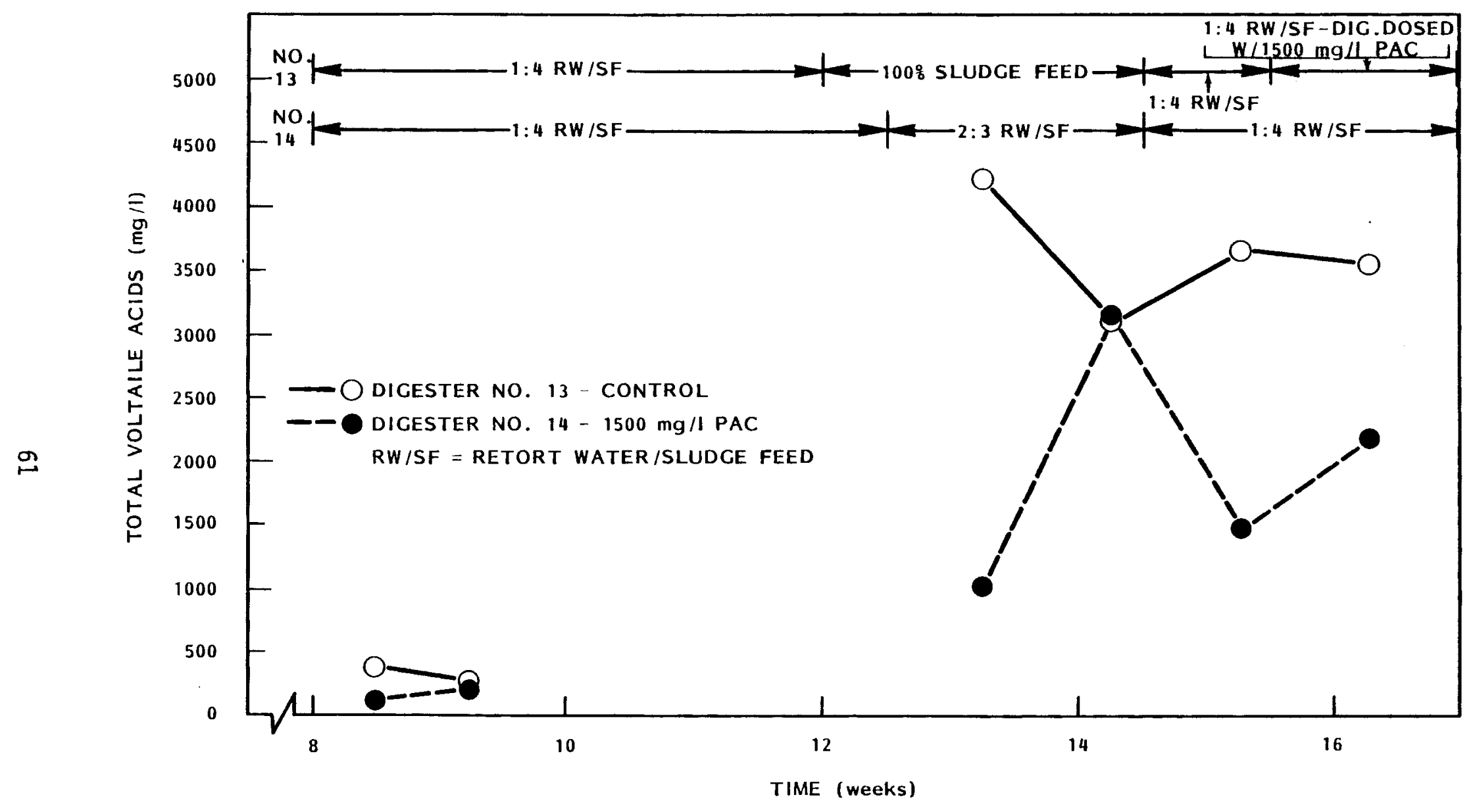

FIGURE 13. Total Volatile Acid Concentrations During the Anaerobic Digestion of Geokinetics Retort Water - Test No. 1 
and signify that the units were relatively unstressed during this portion of the experiment. Thus, it appeared that through the tenth week, both units were functioning normally at the 1:4 feed ratio.

During Week 11, gas production in the digester without carbon dropped to $5 \mathrm{ml} / \mathrm{hr} / \mathrm{l}$ and the unit was near failure. In an attempt to reestablish good digestion, the feed was modified to $100 \%$ sewage sludge. As a result, an increase in the rate of gas generation was observed during Weeks 13 and 14 , as well as a reduction in the concentration of volatile acids. When the 1:4 feed blend was reinitiated, the gas production stabilized at about $15 \mathrm{ml} / \mathrm{hr} / 1$. In an effort to stimulate gas production back to the initial $25 \mathrm{ml} / \mathrm{hr} / 1$ range, the digester was dosed with $1,500 \mathrm{mg} / 1$ powdered carbon. This change had little effect on the process, however, with the final gas conversion efficiencies remaining less than $220 \mathrm{l} / \mathrm{kg}$ VS applied. Volatile acid concentrations were greater than $3,000 \mathrm{mg} / 1$, which indicated that the digester was stressed.

Unlike the control unit, the digester containing $1,500 \mathrm{mg} / 1$ carbon did not experience a decrease in gas production during the eleventh week of the experiment. In fact, gas rates seemed to be stable, indicating that the carbon dosed un it could successfully treat the 1:4 feed blend on a sustained basis. During Week 12, feed to the digester was altered to contain $40 \%$ retort water and $60 \%$ primary sludge. After about 2 weeks gas production had decreased significantly and volatile acids had climbed from approximately $1,000 \mathrm{mg} / 1$ to over $3,000 \mathrm{mg} / 1$. At this point the ratio of retort water in the feed was dropped back to its initial value $(1: 4)$. Gas rates, however, continued to decline during the remainder of the test, with the final volatile acids concentration at nearly $2,500 \mathrm{mg} / 1$.

The research results indicated that the Geokinetics in situ retort water used in the experiment could be anaerobically digested when blended at a 1:4 ratio with primary sewage sludge, and $1,500 \mathrm{mg} / 1$ powdered carbon was added to the unit. Sustained operation at the 1:4 feed ratio without carbon was not successful, nor was digestion with or without carbon at higher feed ratios. The failure to efficiently digest higher loadings of retort water was 
attributed to the presence of toxic materials. Suspected toxicants in the Utah in situ sample included ammonia, sulfur as sulfate and thiosulfate, arsenic, and possibly other heavy metals. The presence of powdered activated carbon appears to ameliorate the effect of the inhibitory substances to a certain extent, probably by adsorbing the toxic materials and removing them from solution.

Test No. 2

The purpose of this test was to assess the feasibility of treating a sample of simulated in situ retort water by anaerobic digestion. The retort water was pretreated by steam stripping to remove about $99 \%$ of the ammonia. In addition, the $\mathrm{pH}$ was adjusted to 7.0 by sparging with $\mathrm{CO}_{2}$ prior to feeding the digester. Characteristics of the sample after steam stripping are illustrated in Table 15. The effect of powdered activated carbon was not examined in the experiment. Two bench-scale digesters were initially charged with 3,500 $\mathrm{ml}$ digested sewage sludge, and then operated at a 25-day SRT using a synthetic feed solution. The synthetic feed consisted of $20 \mathrm{~g} / 1$ tryptone, $20 \mathrm{~g} / 1$ dextrose, and $6 \mathrm{~g} / 1$ beef extract. In addition, a number of nutrients, including nitrogen and phosphorus, were added to the mixture. The synthetic feed had a volatile solids content of $31,700 \mathrm{mg} / 1$ and an estimated $\mathrm{BOD}_{5}$ of $30,000 \mathrm{mg} / 1$.

Gas production rates observed during the experiment are displayed in Figure 14. These reached a maximum of about $20 \mathrm{ml} / \mathrm{hr} / 1$ (380 1/kg VS applied) in both digesters during the second week, and then subsequently decreased to about $15 \mathrm{ml} / \mathrm{hr} / 1$ during Weeks 4 through 6 . As shown in Figure 15, volatile acids concentrations were generally increasing during this period reaching levels in excess of $7,000 \mathrm{mg} / 1$. The high concentrations of acids indicated that neither digester was functioning efficiently. In an effort to improve operation, loading rates for both units were reduced from 1.3 to $0.6 \mathrm{~kg}$ $\mathrm{vs} / \mathrm{m}^{3} /$ day by extending the solids retention times to 50 days. Process efficiency, however, continued to decline with gas rates during the $n$ inth week averaging 190 to $250 \mathrm{l} / \mathrm{kg}$ VS applied, and volatile acid concentrations greater than $8,000 \mathrm{mg} / 1$. 
TABLE 15. Analysis of Steam-Stripped Simulated in situ Retort Water Used in Test No. 2

\begin{tabular}{lc}
\multicolumn{1}{c}{ Parameter } & Composition \\
\cline { 1 - 1 } Total Dissolved Solids, $\mathrm{mg} / 1$ & 4,500 \\
Total Suspended Solids, mg/l & 190 \\
$\mathrm{pH}$ & 10.1 \\
Total Alkalinity, $\mathrm{mg} / 1 \mathrm{CaCO}$ & 11,800 \\
Total Volatile Acids, $\mathrm{mg} / 1$ as Hac & 1,000 \\
Ammonia, mg/l $\mathrm{NH}_{3}-\mathrm{N}$ & 168 \\
Total COD, mg/1 & 6,550 \\
Soluble COD, mg/l & 6,220 \\
Sulfate, mg/l S & 380 \\
Thiosulfate, mg/l S & 180 \\
Thiocyanate, mg/1 S & 100 \\
As $+3, \mathrm{mg} / 1$ & 0.84 \\
As $+5, \mathrm{mg} / 1$ & 0.86
\end{tabular}

Near the end of the ninth week of the experiment, feed to one of the anaerobic digesters was switched to $100 \%$ steam-stripped simulated in situ retort water. During Weeks 10 and 11 both digesters continued operating at a 50-day SRT. Gas production in the unit receiving the artificial substrate increased to about $10 \mathrm{ml} / \mathrm{hr} / 1$, while the rate for the retort water digester appeared to stabilize at approximately $6 \mathrm{ml} / \mathrm{hr} / 1$. Volatile acid levels were high in both units, near $10,000 \mathrm{mg} / 1$, indicating that the anaerobic process was significantly stressed.

During the final 6 weeks of the test, the detention time in the digester operating on retort water was reduced to 25 days. The unit that had previously utilized the synthetic substrate was also fed retort water, but at a 50-day SRT. Throughout this period gas production rates in the digesters steadily declined, eventually reaching zero and complete process failure. During this portion of the test both digesters received a single dose of potassium phosphate $(55 \mathrm{mg} / 1 \mathrm{P})$, calcium chloride $(9.3 \mathrm{mg} / 1 \mathrm{Ca})$, and magnesium chloride $(4.5 \mathrm{mg} / 1 \mathrm{Mg})$. The addition of the nutrients was not effective in reversing 


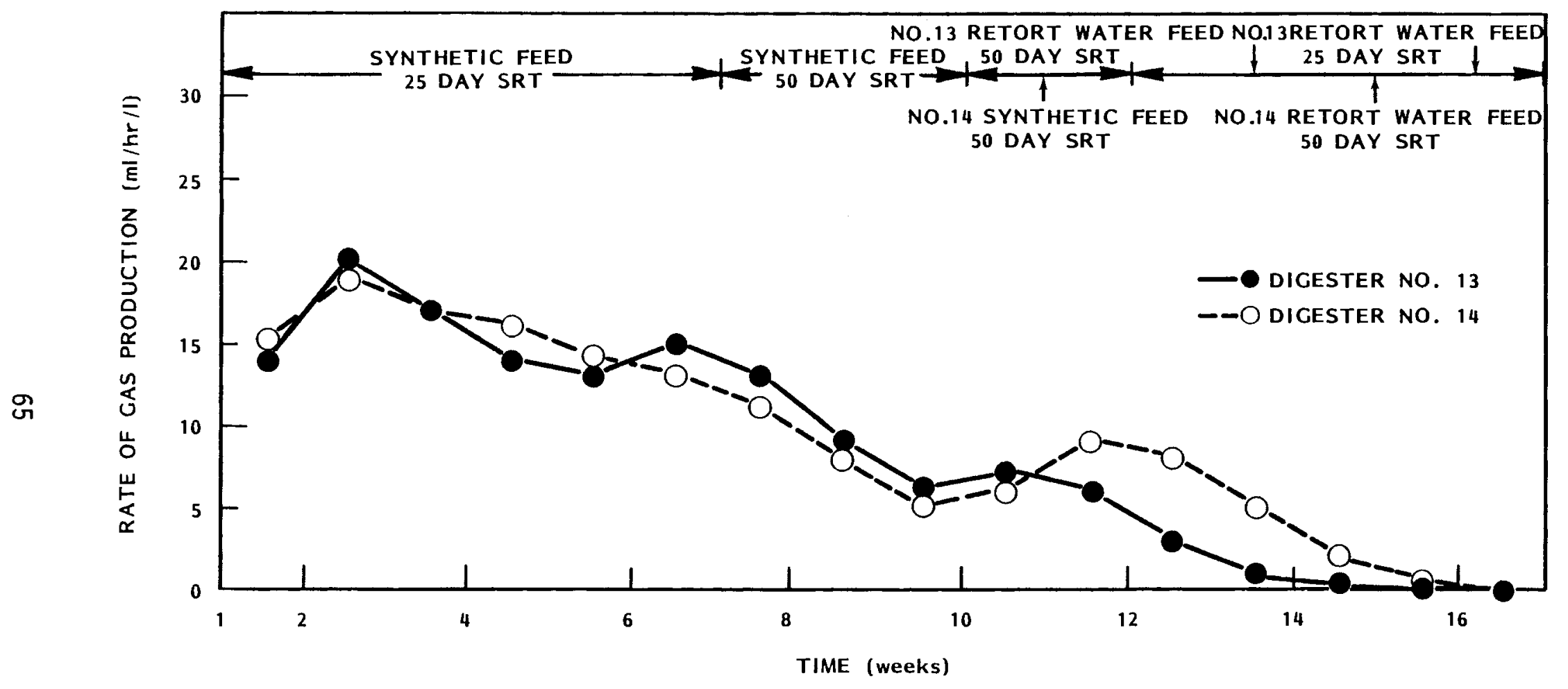

FIGURE 14. Rates of Gas Production for the Anaerobic Digestion of Simulated in situ Retort Water - Test No. 2 


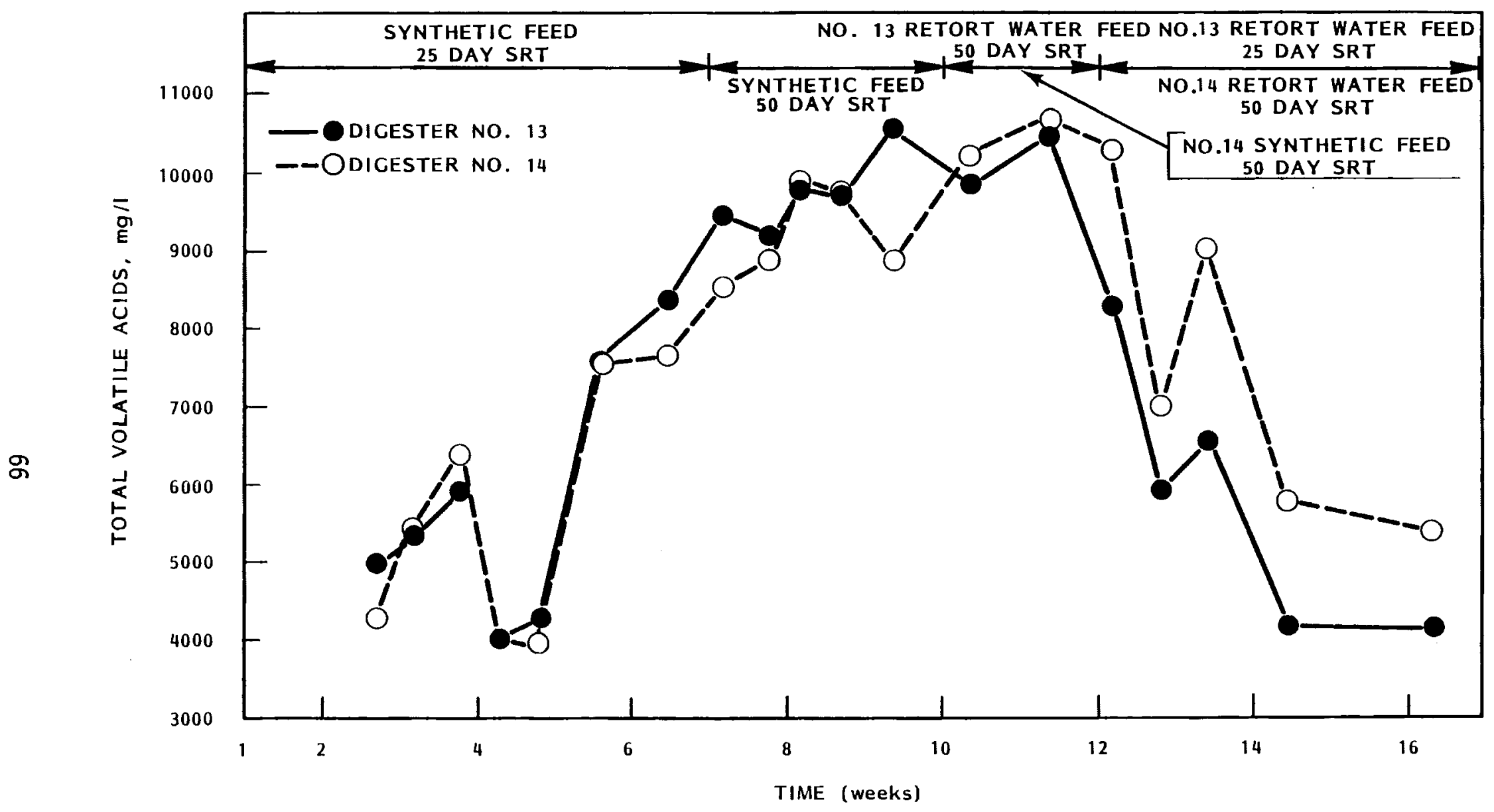

FIGURE 15. Total Volatile Acid Concentrations During the Anaerobic Digestion of Simulated in situ Retort Water - Test No. 2 
the downward trend in gas production. A reduction in volatile acids was presumably due to washout of the acidic components and replacement with retort water.

The intent of the research was to establish efficient steady-state digestion using an artificial substrate, and then replace the synthetic feed with 100\% retort water, and monitor system performance. Unfortunate ly, unstressed digestion was never achieved during the acclimation period. The addition of simulated in situ retort water to both laboratory digesters produced the same effect -- complete process failure. Inability to successfully digest this sample is likely due to the presence of toxic materials. Substances in the retort water that may be responsible for the inhibitory effect include thiosulfate and arsenic.

Test No. 3

The purpose of this experiment was to evaluate the anaerobic digestion of stream stripped simulated in situ retort water in a digester dosed with $2000 \mathrm{mg} / 1$ powdered activated carbon. The purpose of adding powdered carbon was to determine if it would reduce or eliminate the inhibition problem suspected in Test No. 2.

A test unit was initially operated with a primary sewage sludge feed for an 11-week acclimation period at a 12.5-day SRT. A $2000 \mathrm{mg} / 1$ carbon concentration was maintained in the digester during this and all subsequent portions of the experiment. As shown in Figure 16, gas production rates per un it of volatile solids applied ranged between 400 and $6001 / \mathrm{kg}$ for Weeks 5 to 10 . These values are within the range normally expected in a well-operating sewage sludge digester. Volatile acid levels were consistently less than $200 \mathrm{mg} / 1$ during Weeks 9 and 10, and further confirmed that stable performance had been ach ieved.

At the beginning of Week 12 the feed substrate was altered to consist of $100 \%$ retort water and the unit detention time increased to 25 days. Gas rates generally declined during most of the subsequent 6 -week period, but eventually stabilized at about $3751 / \mathrm{kg}$ during Weeks 16 and 17 . The higher in itial 
values were probably attributable to residual sewage sludge that had not yet been completely flushed from the system. Volatile acid levels remained less than $200 \mathrm{mg} / 1$ and indicated that the unit was functioning satisfactorily.

Operation with retort water continued during Weeks 18, 19, and 20, except that the SRT was reduced to 15 days. From Figure 16, values of gas production per unit of volatile solids applied were somewhat lower than previous levels; however, the rates were remarkably stable at about $2751 / \mathrm{kg}$. Volatile acids averaged about $150 \mathrm{mg} / 1$ and a $\mathrm{CH}_{4} / \mathrm{CO}_{2}$ ratio in the off-gas of 2.7 was measured. Thus, it appeared that steady-state operation had been achieved at the 15-day SRT.

The relatively low volatile acid levels in the digester indicated that the methane forming bacteria were not significantly inhibited. Total soluble arsenic in the digester at steady state was approximately $0.6 \mathrm{mg} / 1$, and probably was not sufficient to cause a toxicity problem. Likewise, feed concentrations of ammonia, calcium, sodium, magnesium, phosphorus, sulfate, thiosulfate, and thiocyanate were generally below limits which would produce inhibition. At several points during the test, certain inorganic substances were added to the anaerobic system to ensure that microbial nutrient requirements were satisfied. These additions were designed to contribute the following minimum concentrations: $18 \mathrm{mg} / 1 \mathrm{Fe}, 9.3 \mathrm{mg} / 1 \mathrm{Ca}, 4.5 \mathrm{mg} / 1 \mathrm{Mg}$, and $30 \mathrm{mg} / 1 \mathrm{P}$.

The test successfully demonstrated the anaerobic digestion of steamstripped simulated in situ retort water with the addition of $2000 \mathrm{mg} / 1$ powdered activated carbon. Unstressed operation and stable gas production were achieved; however, nearly all of the gas production resulted from the degradation of volatile acids present in feed substrate. The effectiveness of the process in reducing the concentration of other organic substances in the retort water was not confirmed. The ability of the system to function at a lower carbon dose was not evaluated due to the amount of simulated in situ retort water available for further testing.

Test No. 4

This test involved the anaerobic digestion of surface pilot plant retort water. This sample was much more concentrated than the other retort waters 


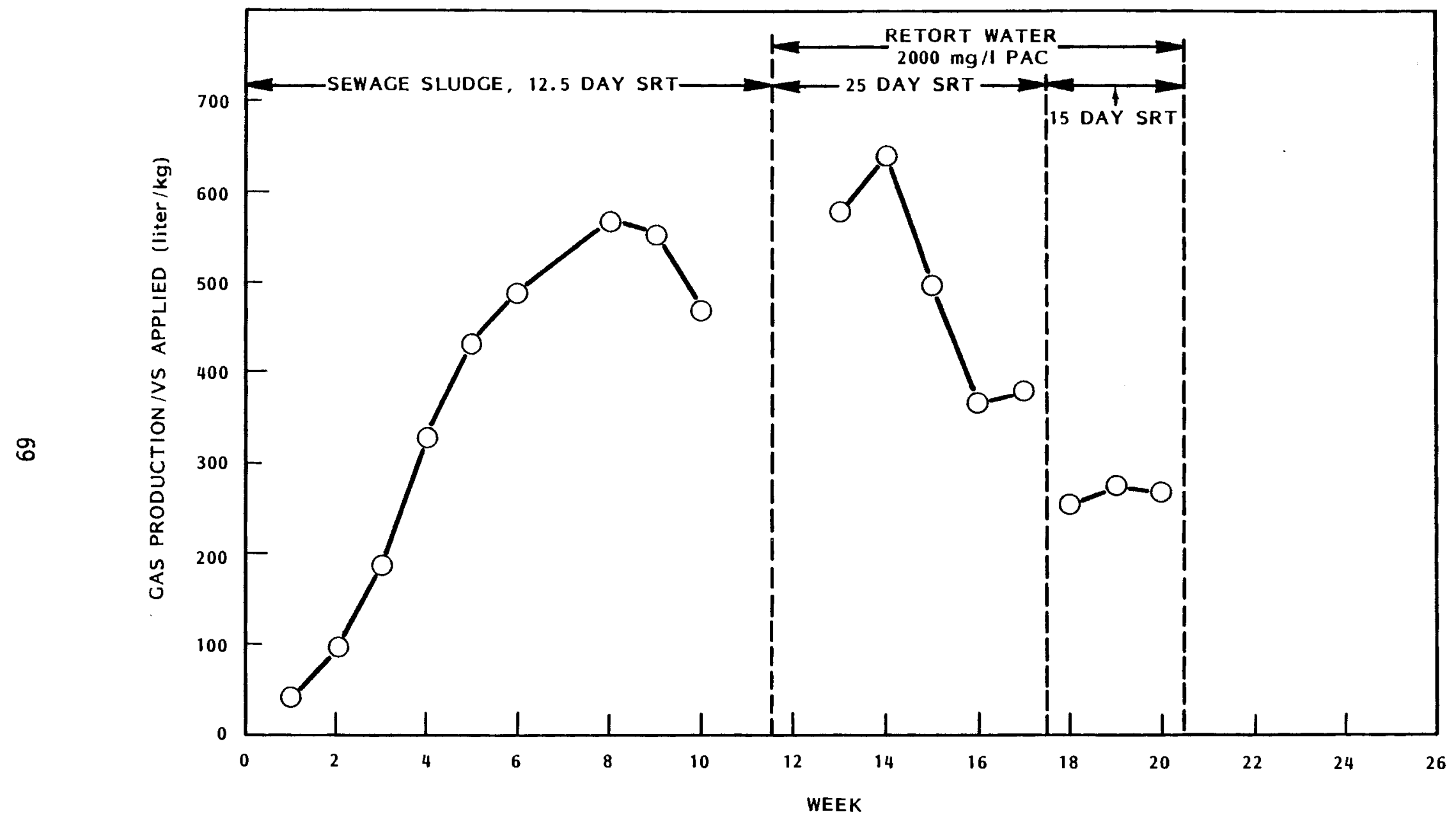

FIGURE 16. Gas Production Per Unit of Volatile Solids Applied for the Anaerobic Digestion of Simulated in situ Retort Water with Carbon Addition - Test No. 3 
tested, and was characterized by a high solids and organic content. Efforts to reduce the ammonia concentration of the raw sample by steam stripping were not successful because the alkalinity in the waste was insufficient. An alternative pretreatment scheme consisted of lime addition to $\mathrm{pH} 11$, boiling of the supernatant fluid for ammonia removal, and subsequent sparging with carbon dioxide to reduce the $\mathrm{pH}$ to near neutral. This method was effective in reducing the ammonia nitrogen concentration from over $20,000 \mathrm{mg} / 1$ to $162 \mathrm{mg} / 1$. It should be noted that the raw sample contained about $25,000 \mathrm{mg} / 1$ thiosulfate as sulfur. Because of its high solubility in aqueous solutions, it is doubtful that the thiosulfate level was significantly reduced by lime addition. Characteristics of the Paraho retort water following pretreatment are listed in Table 16.

TABLE 16. Analys is of Paraho Retort Water After Lime Pretreatment and Air Sparging

$\begin{array}{lc}\text { Total Solids, mg/l } & 121,000 \\ \text { Total Dissolved Solids, } \mathrm{mg} / \mathrm{l} & 109,000 \\ \text { Total Volatile Solids, } \mathrm{mg} / \mathrm{l} & 65,600 \\ \mathrm{pH} & 7 \\ \text { Total Volatile Acids, } \mathrm{mg} / \mathrm{l} \text { as HAC } & 8,500 \\ \text { Ammonia, } \mathrm{mg} / \mathrm{l} \mathrm{NH}_{3^{-\mathrm{N}}} & 162 \\ \text { Arsenic, } \mathrm{mg} / \mathrm{l} & 0.16\end{array}$

This experiment was initiated immediately following Test No. 3 and utilized the same digester that had operated on simulated in situ retort water. The acclimated unit was operated at a 50-day SRT using 100\% treated surface pilot retort water feed. A relatively long detention time was selected for startup because of the high solids concentration of the wastewater. During the first week of operation, gas production per unit of volatile solids applied averaged only $261 / \mathrm{kg}$, and appeared to be decreasing as the test run proceeded. This average compares with an average gas rate of approximately $2751 / \mathrm{kg}$ during the previous 3-week interval when simulated in situ retort water was used. Along with a volatile acids level in excess of $1000 \mathrm{mg} / \mathrm{l}$, the 
data clearly indicated that the test system was severely stressed. As a result of these conditions, the experiment was terminated on $1 y 1$ week after startup.

The poor digester performance may have been due to the presence of a toxic material (or materials) in the surface pilot plant retort water. The untreated wastewater did contain a number of potentially toxic inorganic substances (e.g., boron, copper, zinc); however, these substances probably would not have reached inhibitory concentrations after only 1 week of operation. Additionally, pretreatment with lime reduced arsenic to an acceptable level of $0.16 \mathrm{mg} / 1$. A more likely explanation is that stressed operation was caused by sulfide toxicity resulting from the presence of thiosulfate in the retort water. It is estimated that the concentration of thiosulfate sulfur in the feed substrate was greater than $20,000 \mathrm{mg} / 1$, and much of this was probably converted to sulfide in the reducing environment of the anaerobic system. By comparison, there is generally consensus that soluble sulfide levels in excess of $200 \mathrm{mg} / 1 \mathrm{can}$ be extremely toxic to the digestion process. Thus, successful anaerobic treatment of Paraho retort water will probably be at least partially dependent on providing effective pretreatment for reducing the sulfur concentration.

\section{Test No. 5}

The purpose of this experiment was to assess the anaerobic digestion of Geokinetics retort water that had been pretreated by steam stripping. An attempt to digest the water without prior steam stripping for ammonia removal was unsuccessful in Test No. 1. In both experiments, powdered activated carbon was added to the digesters. Properties of the steam-stripped retort water used for digester feed in Test No. 5 are listed in Table 17. It should be noted that steam stripping reduced the ammonia nitrogen concentration from approximately $3000 \mathrm{mg} / 1$ to $40 \mathrm{mg} / 1$ and effectively eliminated the possibility of ammonia toxicity in the anaerobic system. The pH of the steam-stripped water was reduced to about 7 with carbon dioxide prior to feeding to the digesters. 
TABLE 17. Analysis of Steam-Stripped Geokinetics Retort Water

\begin{tabular}{lc}
\multicolumn{1}{c}{ Parameter } & Concentration \\
\cline { 2 - 2 } Total Solids, mg/l & 16,000 \\
Total Volatile Solids, mg/l & 6,600 \\
$\mathrm{pH}$ & 10.0 \\
$\mathrm{TOC}, \mathrm{mg} / \mathrm{l}$ & 1,140 \\
$\mathrm{COD}, \mathrm{mg} / \mathrm{l}$ & 4,150 \\
Ammonia, mg/l NH $3^{-\mathrm{N}}$ & 40 \\
Total Volatile Acids, mg/l as HAC & 570 \\
$\mathrm{Na}^{+}, \mathrm{mg} / 1$ & 5,000 \\
$\mathrm{~K}^{+}, \mathrm{mg} / 1$ & 73 \\
$\mathrm{Mg}^{++}, \mathrm{mg} / 1$ & 58 \\
$\mathrm{Ca}^{++}, \mathrm{mg} / 1$ & 9 \\
Sulfate, mg/l S & 1,490 \\
Thiosulfate, mg/l S & 1,035 \\
Thiocyanate, mg/l S & 365 \\
Soluble Arsenic, mg/l & 4.4
\end{tabular}

The test digester was initially operated for an 11-week period using a primary sewage sludge feed. The unit functioned at a 12.5-day SRT, and a $2000 \mathrm{mg} / 1$ carbon dose was maintained in the system during this and all subsequent portions of the experiment. Values of gas production per unit of volatile solids applied steadily increased during weeks 1 to 5 and, as shown in Figure 17 , eventually stabilized between 400 and $6001 / \mathrm{kg}$. Volatile acids concentrations were cons istently less than $200 \mathrm{mg} / 1$ for Weeks 9 to 11 and further indicated that unstressed, steady-state performance had been achieved.

At the beginning of Week 12 the digester feed was modified to cons ist of $100 \%$ Geokinetics retort water, and the detention time was extended to 25 days. A progressive decline in the rate of gas production was observed during the ensuing 6-week interval as illustrated in Figure 17 . Gas production per unit of volatile solids applied dropped to only $191 / \mathrm{kg}$ during Week 18 and was 


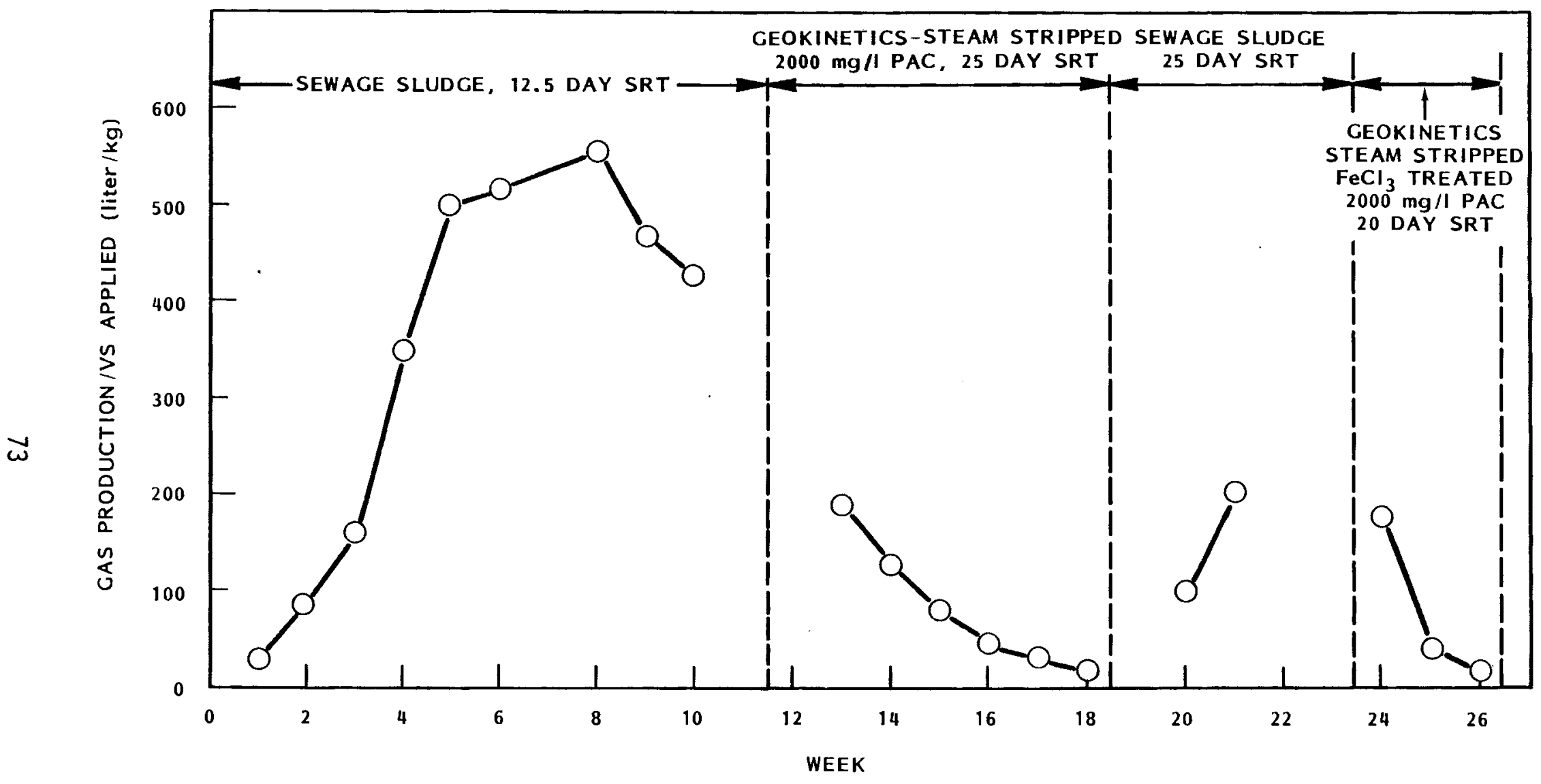

FIGURE 17. Gas Production Per Unit of Volatile Solids Applied for the Anaerobic Digestion of Steam-Stripped Geokinetics Retort Water with Carbon Addition 
substantially below accepted values for normal digestion. The addition of inorganic nutrients $(18 \mathrm{mg} / 1 \mathrm{Fe}, 9.3 \mathrm{mg} / 1 \mathrm{Ca}, 4.5 \mathrm{mg} / 1 \mathrm{Mg}$, and $30 \mathrm{mg} / 1 \mathrm{P}$ ) during the sixteenth week was not effective in improving performance. Average volatile acids levels for Weeks 16 to 18 averaged $260 \mathrm{mg} / 1$ as compared to $570 \mathrm{mg} / 1$ in the feed water.

The poor performance noted with the Geokinetics retort water was suspected to be attributable to the presence of arsenic in the waste. The soluble arsenic concentration in the steam-stripped sample was $4.4 \mathrm{mg} / 1$, somewhat above levels which frequently cause inhibition in sewage sludge digesters. To alleviate this condition, a batch of the steam-stripped retort water was treated with $\mathrm{FeCl}_{3}$, causing a reduction in the arsenic level to $0.16 \mathrm{mg} / 1$. This modified wastewater was then fed to the digester during Weeks 24 to 26 . The unit functioned at a 20-day SRT and, as in all previous portions of the experiment, a $2000 \mathrm{mg} / 1$ carbon concentration was maintained in the digester. Figure 17 shows that gas production rapidly decreased during the period. The un it was near complete failure at week 26, and the test was terminated.

The experimental results suggest that a toxicity problem prevented the successful anaerobic treatment of Geokinetics retort water. Neither pretreatment of the feed by steam stripping, nor carbon addition to the mixed liquor were effective in improving process efficiency. Furthermore, iron treatment of the retort water for arsenic removal had no beneficial impact. Materials that may have been responsible for the stressed performance include sulfur as sulfate, thiosulfate, and sodium. Sulfate and thiosulf ate accounted for about $2500 \mathrm{mg} / 1$ sulfur in the retort water feed. Significant portions of these substances were likely reduced to sulfides in the digester, very possibly exceeding inhibitory levels. The sodium concentration was $5000 \mathrm{mg} / 1$, which is generally considered toxic in sewage sludge digesters. Effective anaerobic digestion of Geokinetics retort water will likely require the implementation of pretreatment methods for removing these materials. 


\section{ACTI VATED SLUDGE TREATMENT}

Experimental Methods

Activated sludge studies were carried out in both continuous-flow and fill and draw reactors. Continuous flow experiments were conducted with 10-1 or 3-1 complete mix laboratory reactors constructed of clear acrylic plastic with adjustable baffles separating the aeration chambers from the settling chambers (Metcalf and Eddy, Inc., 1972). During the course of the experiments wastewater was pumped continuously to the aeration chamber where it was contacted with activated sludge (biological $\mathrm{floc}$ ) in the presence of 2 to $5 \mathrm{mg} / 1$ of dissolved oxygen. The mixture of activated sludge and wastewater (mixed liquor) is agitated vigorously by air sparging in the aeration chamber, then flows under the baffle to the settling chamber. The activated sludge separates from the liquid phase in the settling chamber and eventually drops back into the mixing zone below the baffle and is drawn back into the aeration chamber. A small amount of sludge tends to collect on the walls and in the outer corners of the settling chamber over a period of several hours. This sludge was recirculated back into the aeration chamber by periodically raising the baffle to the surface of the mixed liquor and by diverting a jet of mixed liquid against the outer wall and corners of the settling chamber for 2 min every $4 \mathrm{hr}$. Clarified liquid in the settling chamber overflows to a collection vesse 1 through a tube located near the top of the settling chamber. The settling chamber volume is 20 to $40 \%$ of the aeration chamber volume. The entire contents of the aeration chamber and settling chamber were thoroughly mixed and sampled each day to determine the mixed liquor volatile suspended solids (MLVSS). Samples of influent and clarified effluent were also sampled periodically for analysis.

Fill and draw experiments were conducted in glass beakers or graduated cylinders equipped with magnetic stirrers to assure good mixing during the aeration phase. The aeration phase lasted $23 \mathrm{hr}$ out of each day during which wastewater was added gradually by intermittent pumping. Following aeration, the mixed liquor was allowed to settle for $1 \mathrm{hr}$ and the supernatant liquid was decanted to the desired volume. The aeration and mixing was then resumed, and samples of the mixed liquor were taken for MLVSS determinations before wastewater addition was resumed. 
Analys is of samples for BOD, COD, thiocyanate, and nonfilterable residue were performed according to procedures given in Standard Methods (14 th Ed.). Total organic carbon was determined with a Beckman 915 analyzer after acidifying and nitrogen sparging of the samples to minimize inorganic carbon levels. Volatile organic matter was minimal in these samples due to prior steam stripping of the retort water. Thiosulfate was determined by iodometric titration and was found to agree with in $10 \%$ of values determined by ion chromatography. No sulfide or sulfite interference was present in the steam-stripped retort water.

Results and Discussion

Several unsuccessful attempts were made to acclimate activated sludge cultures to retort water in continuous flow experiments with mixtures of synthetic retort water and actual retort water. The synthetic retort water was formulated to yield moderate concentrations of dissolved mineral salts commonly found in in situ retort waters in addition to moderate TOC, COD, and BOD concentrations derived largely from acetate ion. The compositions of the synthetic retort water are given in Table 18 .

TABLE 18. Composition of Synthetic Retort Water

\begin{tabular}{lcc} 
Constituent & Concentration, $\mathrm{mg} / \mathrm{l}$ \\
\cline { 1 - 2 } $\mathrm{Na}^{+}$ & 2050 \\
$\mathrm{~K}^{+}$ & 140 \\
$\mathrm{NH}_{4}^{+}$ & 730 \\
$\mathrm{Mg}^{+2}$ & 60 \\
$\mathrm{Ca}^{+2}$ & 70 \\
$\mathrm{Cl}^{-}$ & 1820 \\
$\mathrm{HCO}_{3}^{-}$ & 250 \\
$\mathrm{SO}_{4}^{-}$ & 1450 \\
Acetate $^{-}$ & 2960 \\
Octanoate & 500 \\
Acetamide & 300 \\
Pheno 1 & 20 \\
m-Cresol & 20 \\
TOC & 1380 \\
BOD & 3000
\end{tabular}


The relatively low concentrations of ammonium and bicarbonate ions were selected to reflect pretreatment by steam stripping. Most of the remaining ammonium ion is "fixed" and would require additional alkalinity for complete removal by steam stripping.

Acclimation studies were conducted by initially feeding $100 \%$ synthetic retort water to an activated sludge culture obtained from a municipal or industrial wastewater treatment plant. All of the activated sludge cultures tested were found to adapt quickly to the synthetic wastewater. Following the initial feeding of $100 \%$ synthetic retort water, step-wise increases in actual retort water (Geokinetics) were introduced with the synthetic retort water until the activated sludge reactor was receiving $100 \%$ actual retort water. The Geokinetics retort water had been previously steam-stripped to reduce the ammonia levels to less than $500 \mathrm{mg} / 1$ to avoid toxicity problems with this constituent. Phosphate was added to the wastewater as a growth nutrient to provide a minimum of 2 parts of phosphorus to 100 parts of BOD. Additional phosphorus was available in those experiments where phosphate was used as a pH buffer. Essential micro-nutrients, including iron, copper, manganese, zinc, cobalt, molybdenum, and boron, were also added to assure the availability of these elements for cell growth.

The results of an attempt to acclimate an activated sludge culture to steam-stripped Geokinetics retort water are illustrated in Figure 18. Total organic carbon (TOC) removal exceeded $95 \%$ for wastewater feed comprised of $100 \%$ synthetic retort water introduced to the activated sludge reactors at a TOCMLVSS ratio of 0.25 . A 10-1 continuous flow reactor was used in this experiment with step-wise increases in the percentage of actual retort water (Geokinetics No. 3) to $100 \%$ after 43 days. TOC removal averaged about $30 \%$ for the undiluted Geokinetics No. 3 water. The daily sludge growth rate increased from about $7 \%$ for the pure synthetic to about $11 \%$ for the $5 \%$ retort water, then decreased thereafter. The average daily sludge growth rate was $3 \%$ during the final week on $100 \%$ Geokinetics No. 3 retort water.

The activated sludge was frozen and stored for 3 months prior to use in the second phase of this acclimation experiment using steam-stripped Geokinetics No. 4 retort water. The frozen activated sludge was thawed and blended 


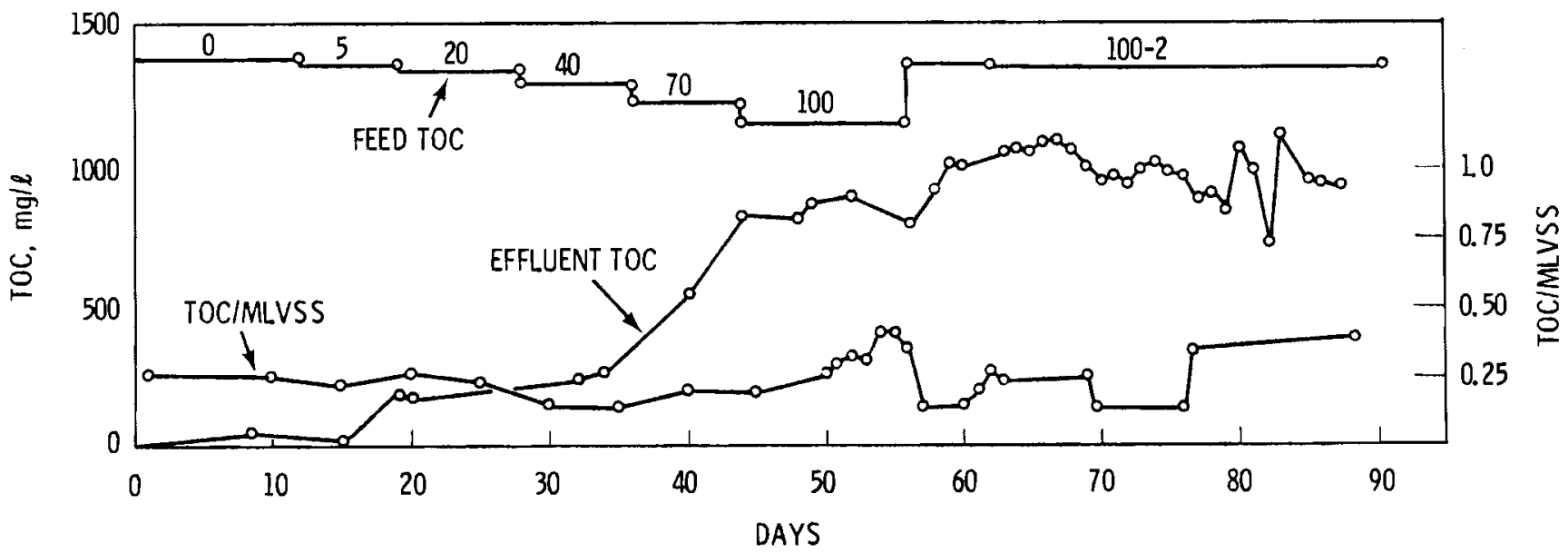

FIGURE 18. Comparison of Feed and Eff luent TOC with TOC/MLVSS Ratio During Activated Sludge Acclimation Experiment

at a ratio of approximately 1:1 with a fresh activated sludge sample from a petroleum refinery wastewater treatment facility. The mixed sludge was used in a 3-1 continuous flow reactor for a period of 12 days beginning on Day 56 of Figure 18. A portion of this sludge was then transferred to a 1-1 fill and draw reactor for the remainder of the experiment. TOC removal and average daily sludge growth averaged about $30 \%$ and $1 \%$, respectively, during the fill and draw period of this experiment. Microscopic examination of the activated sludge revealed the disappearance of rotifers and ciliates in the transition period from 40 to $70 \%$ retort water. These organisms also disappeared from the mixed activated sludge containing activated sludge from the petroleum refinery wastewater treatment facility used in treating Utah in situ No. 4 retort water. Thiosulfate removal determined during the fill and draw period exceeded 95\% while essentially no thiocyanate was removed. Thiocyanate destruction is reported to be a good indicator of the health of the activated sludge (Ashmore et al., 1967). Analys is of a $20 \%$ actual retort water feed sample and an effluent sample taken on the twenty-sixth day indicated $89 \%$ removal of thiocyanate from a feed concentration $100 \mathrm{mg} / 1 \mathrm{CNS}^{-}$which indicates a healthy sludge during the in itial part of the acclimation period. BOD removals of 31 , 32 , and $43 \%$ were measured on three effluent samples during treatment of 
Geokinetics No. 3 retort water. The BOD results are questionable, however, since subsequent work revealed that the Standard Methods' BOD test may not include thiosulfate unless special precautions are taken (Wong and Mercer, 1979). No thiosulfate data are available on the samples tested for BOD.

Two fill and draw activated sludge tests with 11 of mixed liquor each were undertaken following a different approach to acclimation of the sludge. Activated sludge from the petroleum refinery wastewater treatment plant was found to be readily acclimated to retort water that had been treated with a column of granular activated carbon. Step-wise increases in the percent of noncarbon treated retort water over a period of 5 weeks produced an activated sludge which was much more effective in treating the retort water than previous sludges. Treatment with powdered activated carbon (PAC) was evaluated in one test concurrently with no PAC treatment in the other test. Steam-stripped Geokinetics No. 3 and 4 retort water was used in the tests to determine the feasibility of biological treatment on this type of retort water with and without PAC treatment. Both retort waters were initially pretreated for arsenic removal to avoid potential toxicity problems with this element. Pretreatment for arsenic removal consisted of ferric hydroxide-manganese dioxide scavenging which will be discussed in the section on elemental analysis. Feed compositions are given in Table 19 (essential micronutrients and phosphate were

TABLE 19. Feed Compositions for Activated Sludge Test Reactors

\begin{tabular}{|c|c|c|c|}
\hline & $\begin{array}{r}\text { With A } \\
\text { Pretreat } \\
\end{array}$ & $\begin{array}{l}\text { emoval } \\
\mathrm{t}, \mathrm{mg} / \mathrm{l} \\
\end{array}$ & $\begin{array}{l}\text { Without As Removal } \\
\text { Pretreatment, mg/l }\end{array}$ \\
\hline & $\begin{array}{l}\text { Geokinet ics } \\
\text { No. } 3 \\
\end{array}$ & $\begin{array}{l}\text { Geokinet ics } \\
\text { No. } 4 \\
\end{array}$ & $\begin{array}{c}\text { Geokinetics } \\
\text { No. } 4 \\
\end{array}$ \\
\hline TOC & 1010 & 1360 & 1380 \\
\hline $\mathrm{COD}$ & 3910 & 5400 & 5990 \\
\hline $\mathrm{CNS}^{-}$ & 315 & 250 & 250 \\
\hline $\mathrm{S}_{2} \mathrm{O}_{3}$ as $\mathrm{S}$ & 890 & 990 & 1450 \\
\hline$B O D(a)$ & -- & 1300 & -- \\
\hline As & 0.8 & 1.4 & 8.5 \\
\hline
\end{tabular}

(a) Probably includes little, if any, oxygen demand from thiosulfate. 
added as in the previous activated sludge experiments). Figures 19 and 20 illustrate influent and effluent TOC concentrations, organic loading (TOC/MLVSS) and $\mathrm{pH}$. The data also included the final two-step increases ( 80 and $90 \%$ ) of the acclimation period. PAC treatment for the first 21 days in Figure 19 consisted of contacting the feed batch used each day with $2000 \mathrm{mg} / \mathrm{l}$ $P A C$ in a mixing vessel for $10 \mathrm{~min}$, then filtering the liquid to remove the PAC. Approximately $800 \mathrm{mg} / 1$ of PAC was in the mixed liquor of the PAC test at the beginning of the time period indicated in Figure 19, but this diminished

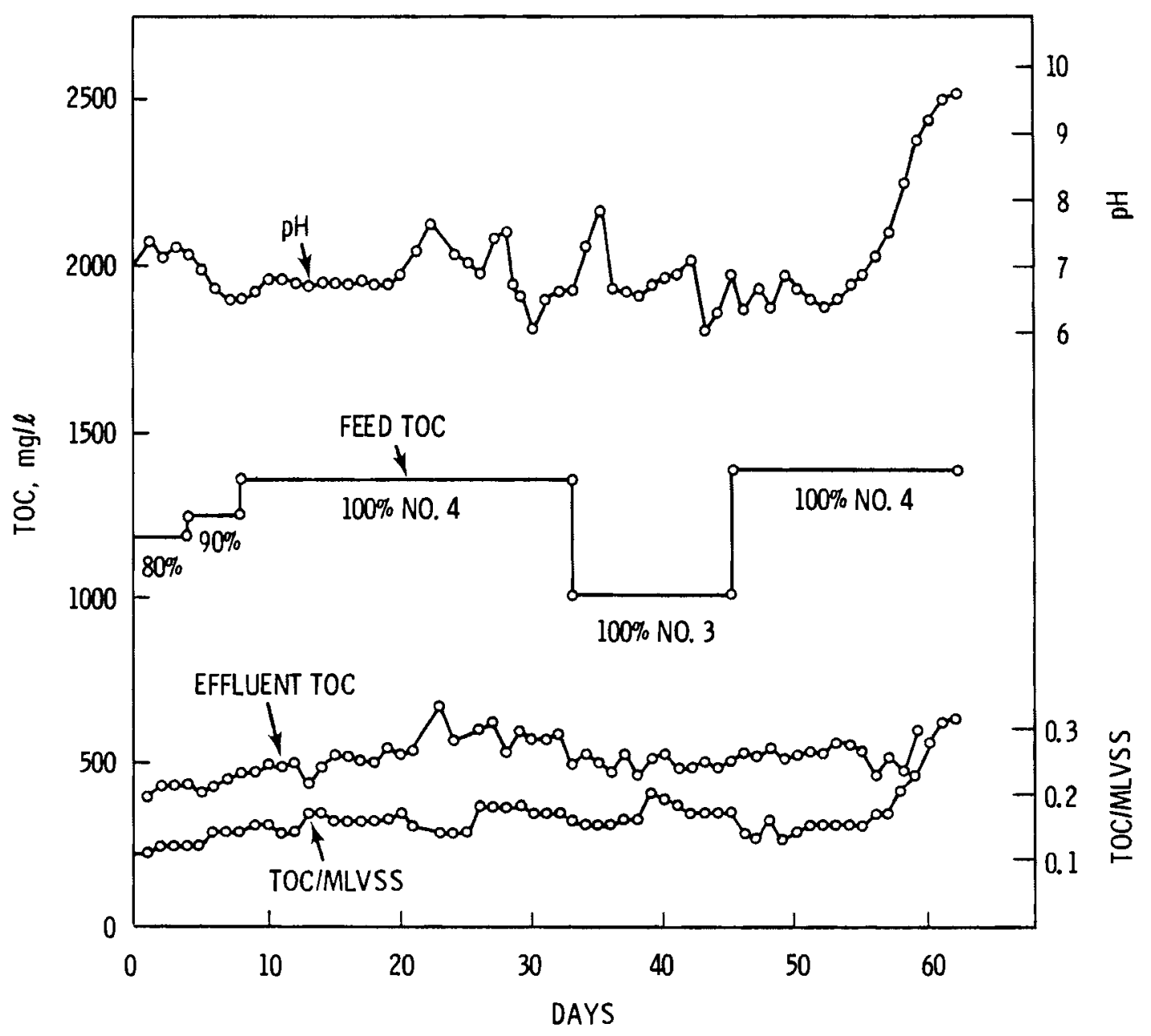

FIGURE 19. Organic Carbon Influent, Effluent and Loading Values with PAC Treatment. MLVSS averaged $4300 \mathrm{mg} / 1$ from day 8 to day 33 with a solids retention time of about 20 days. 


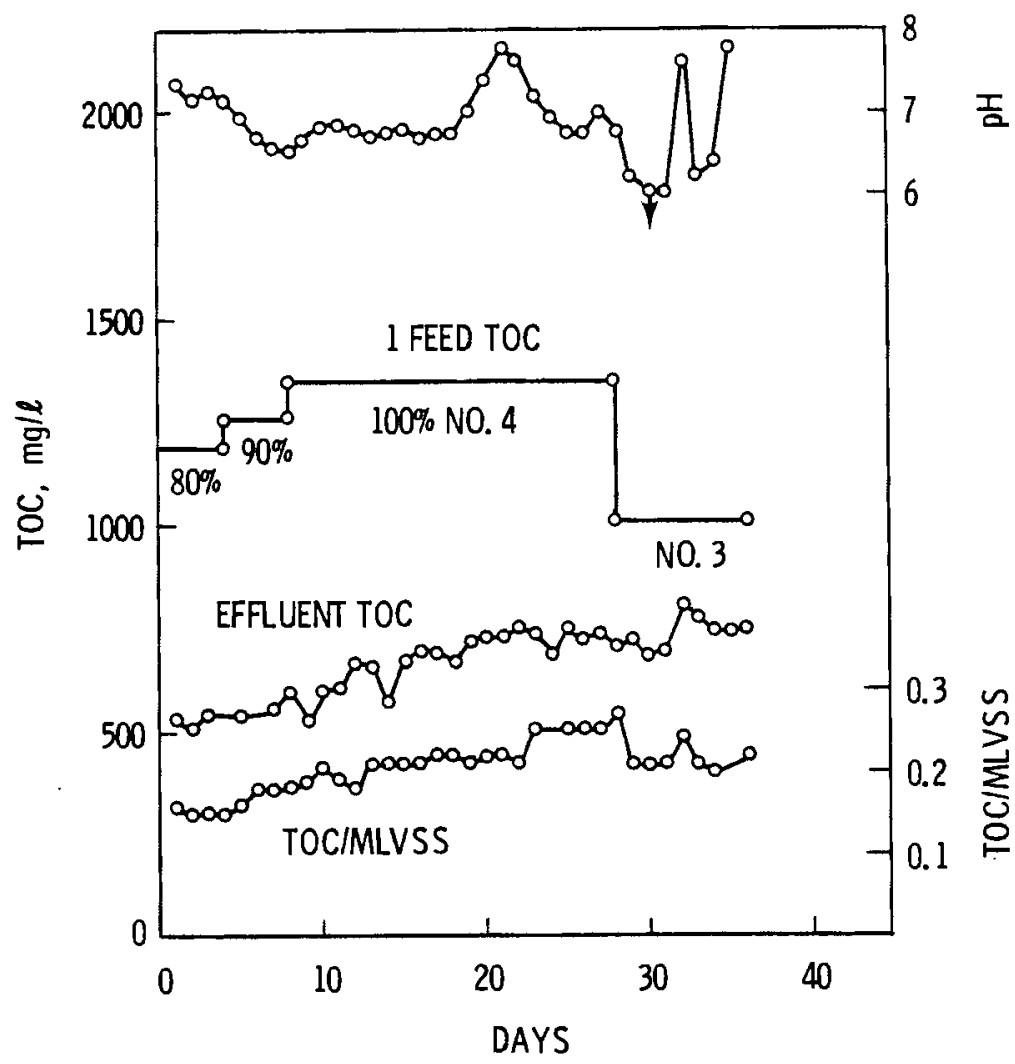

FIGURE 20. Organic Carbon Influent, Effluent and Loading Values Without PAC Treatment

to about $300 \mathrm{mg} / 1$ at the end of the 21-day period because of sludge wasting. The daily treatment of the feed with $2000 \mathrm{mg} / 1$ PAC removed only $6 \%$ of the TOC from the feed, but when coupled with the presence of PAC in the mixed liquor it appeared to be somewhat effective in reducing the stress of toxicants on the activated sludge. Microscopic examination of the activated sludge in each test vesse 1 indicated a loss of rotifers, stalked and mobile ciliates and worms during the acclimation period. However, the PAC test reactor retained flagellates that were not retained by the reactor receiving no PAC treatment. Furthermore, the removal of thiocyanate, $\mathrm{CNS}^{-}$, was considerably greater for PAC treatment (see Figure 21) than without PAC treatment (see Figure 22). 


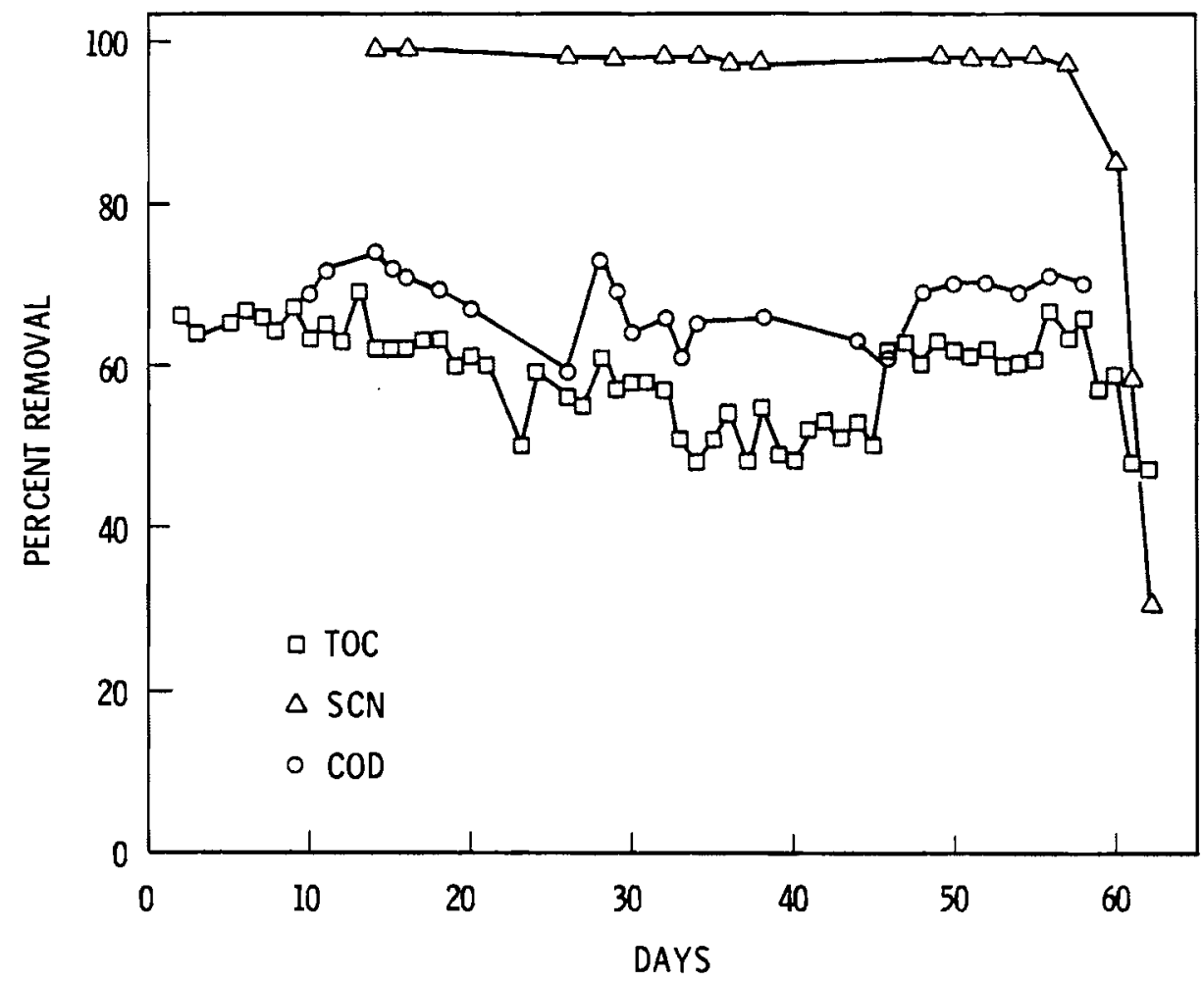

FIGURE 21. Removal of TOC, COD and Thiocyanate with PAC Treatment

Some of this difference in $\mathrm{CNS}^{-}$removal may be attributed to a lower organic and COD loading in PAC-treated reactor since this reactor received an average of about $20 \%$ less TOC and COD than the reactor with no PAC treatment. During periods when the PAC-treated reactor received a $12 \%$ lower organic loading (Figure 19, Days 26-33; and Figure 20, Days 8-15), the percent TOC and COD removals were only slightly better with PAC treatment (see Table 20).

Thiosulfate removal exceeded $95 \%$ in each reactor during these periods and remained above $93 \%$ until the end of each test. A BOD removal of greater than 99\% was measured on the reactor receiving no PAC treatment. However, the BOD results are suspected of not representing the true $B O D$ values since little, if any, thiosulfate oxygen demand may be included. Nevertheless, because more than $95 \%$ of the thiosulfate is oxidized, high BOD removals would be anticipated. PAC treatment was modified at the 22-day point on Figure 19 to addition of $300 \mathrm{mg} / 1$ PAC to the feed as before, but with settling after the 10-min contact period. The settled PAC was then separated by decanting the 
supernatant liquid and the PAC was added directly to the reactor as a slurry in about $10 \%$ of the daily feed volume. The reactor volume was also reduced to $500 \mathrm{ml}$ of mixed liquor at this point to extend the test period with the limited amount of retort water available. A $10 \%$ reduction in TOC removal occurred the day after this modification which also coincided with a $\mathrm{pH}$ increase. Insufficient time for $\mathrm{pH}$ stabilization after acid addition to the feed is believed responsible for this $\mathrm{pH}$ increase. The $\mathrm{pH}$ fluctuations that occurred during the Geokinetics No. 3 feed addition resulted from the lack of phosphate buffering. Phosphate buffer was not used during this period since the phosphate interferred with the alum coagulation tests planned for this effluent.

The reactor receiving no PAC treatment appeared to be stabilizing with respect to TOC removal in the final six days with No. 4 feed; however, the test period was too short to actually confirm this. A substantial decrease in CNS $^{-}$removal occurred during this time, which may be attributed to the $12 \%$ increase in organic loading. Unfortunately $\mathrm{pH}$ control was lost after th is when No. 3 feed was introduced without phosphate buffering. A pH reduction to 4.2 was experienced on Day 30 of Figure 20 and the test was terminated several days later when $\mathrm{CNS}^{-}$removal dropped to near zero.

Sufficient $\mathrm{PH}$ control was maintained in the test reactor receiving PAC to sustain good biological oxidation of $\mathrm{CNS}^{-}$contained in the No. 3 feed. However, the percentage of TOC and COD removed from No. 3 feed was less than that for No. 4 feed. The introduction of No. 4 feed, without the arsen ic removed, after No. 3 was completed did not appear to affect the operation of the test reactor. The phosphate buffer was not added to the No. 4 feed during the final week of this test to determine the effect of a pH increase on the operation of the reactor. The $\mathrm{pH}$ increase results from carbon dioxide stripping from the high sodium bicarbonate concentration in the retort water during aeration. As evident in Figure 21, TOC and $\mathrm{CNS}^{-}$reduction decreased rapidly coinciding with the $\mathrm{pH}$ increase. 


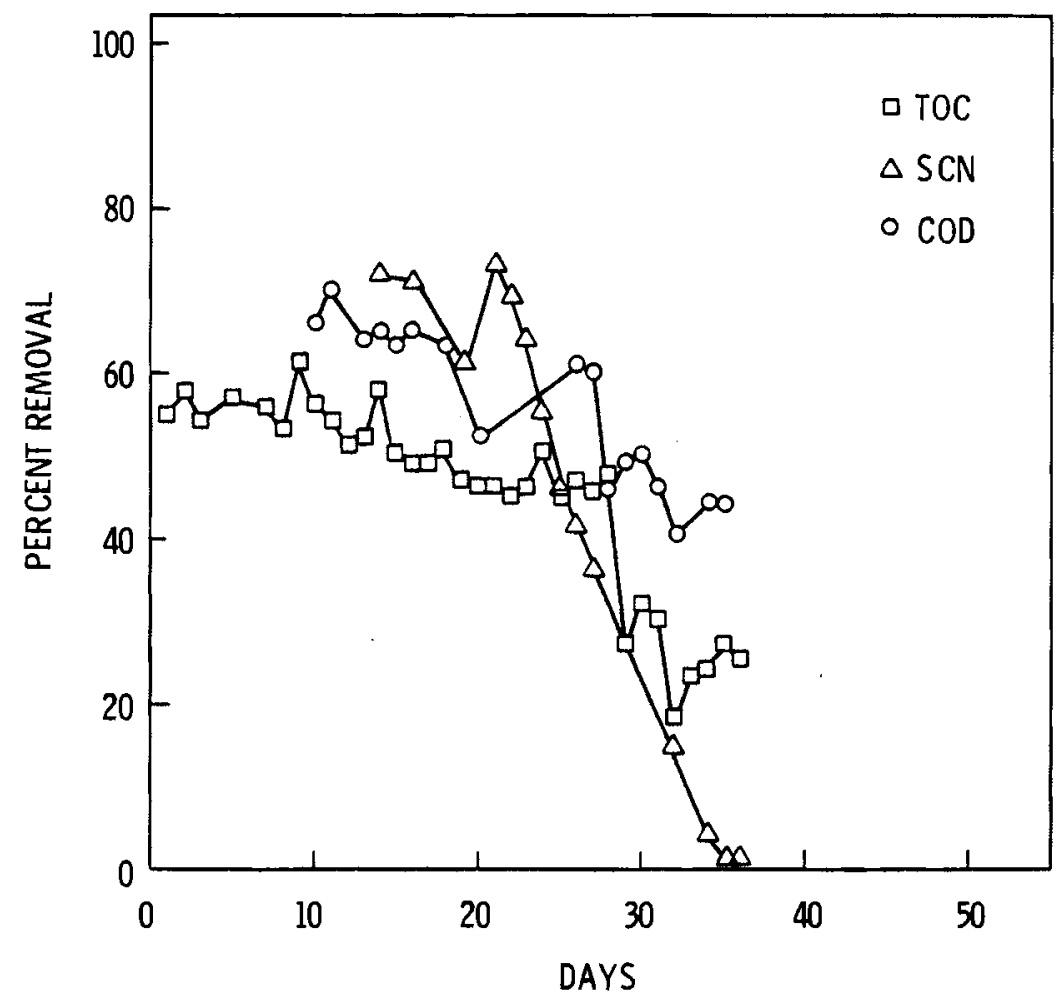

FIGURE 22. Removal of TOC, COD and Thiocyanate Without PAC Treatment

TABLE 20. Comparison of Pollutant Removals with Activated Sludge With and Without PAC Treatment

$$
\begin{gathered}
\text { With PAC Treatment, Without PAC Treatment, } \\
\% \text { Removal }
\end{gathered}
$$

Pollutant (Figure 19, Days 26-33) (Figure 20, Days 8-15)

TOC

57

55

$\mathrm{COD}$

$B O D^{(a)}$

66

65

$\mathrm{S}_{2} \mathrm{O}_{3}$

$--$

99

$\mathrm{SCN}^{-}$

95

95

99

72

(a) Probably includes little, if any, effect from thiosulfate oxygen demand. 
ACTI VATED CARBON ADSORPTION

Adsorption isotherm and column tests were conducted to evaluate activated carbon for removal of retort water constituents such as organic carbon, COD, and thiocyanate from stream stripped and biologically treated retort water.

\section{Experimental Methods}

Adsorption isotherm tests with retort water were performed at room temperature $\left(21^{\circ} \pm 1^{\circ} \mathrm{C}\right)$ with Calgon Filtrasorb 400 which was pulverized and screened to produce a $200 \times 400$ mesh fraction. The $200 \times 400$ mesh carbon was washed in distilled water and dried at $103^{\circ} \mathrm{C}$ prior to preparation of a $200 \mathrm{~g} / 1$ slurry in distilled water. This slurry was used for measuring activated carbon additions in the isotherm tests. The procedure used for the adsorption isotherm tests was patterned after the basic procedure used for nonvolatile organic compounds by Richard A. Dobbs, Richard J. Meddindorf, and Jesse M. Cohen, of the Environmental Protection Agency's Municipal Environmental Protection Research Laboratory at Cincinnati, Ohio. The nonvolatile isotherm test procedure was employed because volatile matter in the retort water had previously been removed by steam stripping.

Adsorption isotherm tests were performed on steam-stripped Geokinetics No. 3 retort water with and without biological treatment. The bio-treated water consisted of alum clarified and filtered effluent from the activated sludge test unit receiving steam-stripped feed with $300 \mathrm{mg} / 1$ PAC (see Figure 19). Only combined effluent from day 40 to day 45 of the activated sludge experiment was used to allow flushing of phosphate buffer and previous feed solution from the test unit. Only nutrient phosphorus at a concentration of $43 \mathrm{mg} / 1 \mathrm{PO}_{4}-\mathrm{P}$ was added to the feed of the activated sludge unit. A minimum phosphate addition was desired during this phase of the activated sludge to avoid interference with the alum coagulation step. A rapid settling floc was obtained by adding $300 \mathrm{mg} / 1$ alum and $1 \mathrm{mg} / 1$ anionic polymer to the activated sludge effluent. Small beaker tests indicated that $300 \mathrm{mg} / 1$ alum was optimum for clarification of the effluent. The alum clarified effluent was adjusted 
to $\mathrm{pH} 7.0$ and filtered with a $0.45 \mu$ membrane filter to remove the remaining traces of suspended matter. One hundred $\mathrm{ml}$ portions of the filtered effluent were $\mathrm{placed}$ in $250 \mathrm{ml}$ beakers equipped with magnetic stirrers. From 0.5 to $5 \mathrm{mls}$ of $200 \mathrm{~g} / 1$ activated carbon slurry were also added to each beaker. The volume of mixture in each beaker was adjusted to $105 \mathrm{ml}$ with distilled water and the contents were vigorously mixed for one hour. At the end of the mixing period, the slurry was filtered through a $0.45 \mu$ membrane filter and the filtrate was analyzed for TOC. Two blanks were determined by the same procedure, but without addition of activated carbon. The blanks were used to establish the in itial TOC concentrations which were slightly lower $(-5 \%)$ than feed solution due to adsorption on the filter and walls of the containers. An adsorption isotherm was also determined for steam-stripped Geokinetics. No. 3 retort water which had not received biological treatment. This water was adjusted to pH 7.0 and filtered through a $0.45 \mu$ membrane filter without alum treatment.

Activated carbon column tests were conducted with two column sizes:

1) 1.8-cm diameter by $10-\mathrm{cm}$ deep with $50 \times 120$ mesh Filtrasorb 400 and 2) $5.08-\mathrm{cm}$ diameter by $61-\mathrm{cm}$ deep with $14 \times 30$ mesh Filtrasorb 400 . Flow rates were $3.9 \mathrm{mls} / \mathrm{min}$ for the small column and $41 \mathrm{mls} / \mathrm{min}$ for the large column. The large column was used only with steam-stripped Utah in situ No. 4 retort water without biological treatment to prepare feed for the acclimation phase of the activated sludge treatability study. The small carbon columns were used with both biotreated and nonbiotreated steam-stripped Utah in situ No. 4 retort water. The biotreated wastewater contained $10.8 \mathrm{~g} / 1$ of phosphate ion buffer and was treated with a large lime dose $\left(214 \mathrm{mls}\right.$ of $0.2 \mathrm{~g} / 1 \mathrm{Ca}(\mathrm{OH})_{2}$ slurry) to effect good clarification of suspended matter. Alum clarification was ineffective because of the high phosphate concentration. The lime treated wastewater was clarified by sedimentation, adjusted to $\mathrm{pH} 7.0$ and filtered through Whatman No. 1 filter paper.

Adsorption I sotherms

The activated carbon adsorption data were plotted according to the Freundich equation which has the form: 


$$
\frac{x}{m}=k c_{f}^{\frac{1}{n}}
$$

where $x=$ amount of solute adsorbed, $m g / 1$

$m=$ weight of carbon, $g / 1$

$C_{f}=$ concentration of solute in solution at equilibrium, mg/l

$K=$ intercept at $C_{f}=1$

$\frac{1}{n}=$ slope of the line.

In logarithmic form, this equation is:

$$
\log \frac{x}{m}=\log K+\frac{1}{n} \log C_{f}
$$

The adsorption data for the steam-stripped retort water with and without biological treatment are plotted in Figure 23. The TOC isotherm for the biotreated retort water is higher than the nonbiotreated retort water and has less slope which indicates that the TOC adsorption capacity is greater and decreases less rapidly with decreasing $C_{f}$ values. It can be predicted from this data that lower TOC effluents can be achieved with a given amount of carbon with biotreated retort water than with nonbiotreated retort water. Biological treatment effectively complements activated carbon adsorption by removing constituents such as lower aliphatic acids which are not adsorbed well by activated carbon at near neutral $\mathrm{pH}$ levels.

Values for the slope of the lines $\left(\frac{1}{n}\right)$, intercept $(K)$, and the correlation coefficient $(r)$ are given below:

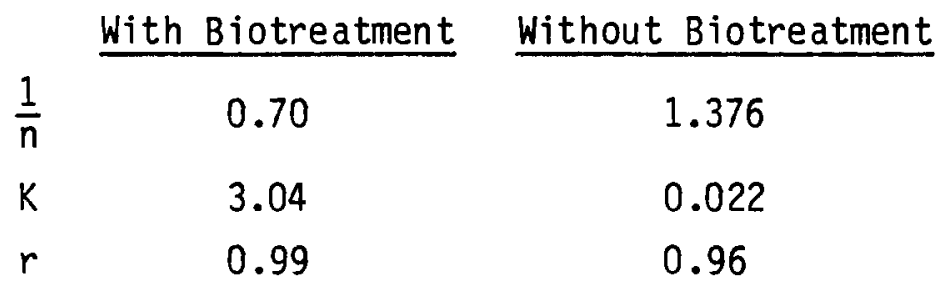




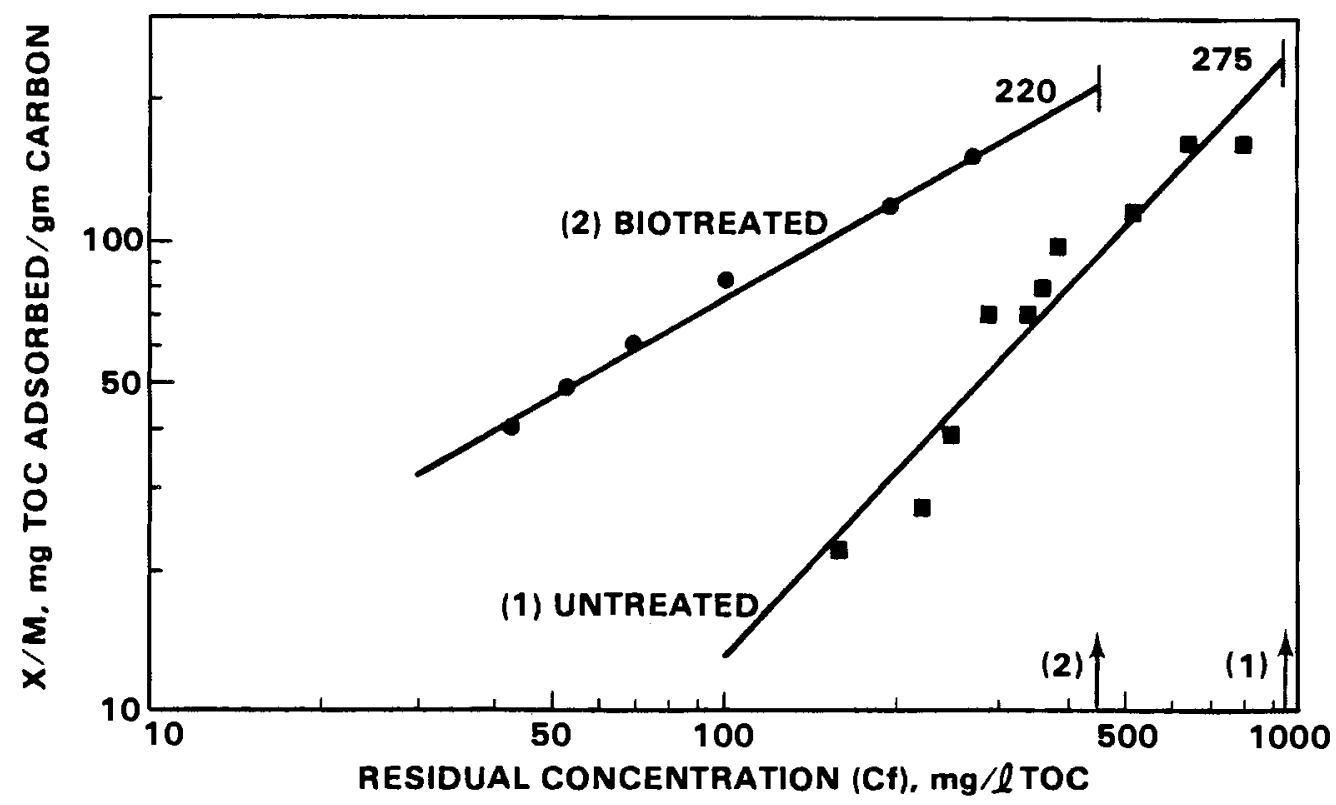

FIGURE 23. Carbon Adsorption Isotherm for Steam-Stripped Geokinetics Retort Water

The intercept $K$ is roughly an indicator of the TOC adsorption capacity and is about two orders of magnitude larger for biotreated retort water than for nonbiotreated retort water. The correlation coefficient $r$ is computed by linear regression analys is and denotes how closely the data points $f$ it the line $(r=1$ for a perfect fit).

\section{Column Studies}

Figures 24 and 25 illustrate TOC and COD removal with granular activated carbon columns receiving biotreated and nonbiotreated steam-stripped Utah in situ No. 4 retort water. Breakthrough of both TOC and COD occurred very early with the nonbiotreated retort water. A substantial fraction (20\%) of the COD in this water is due to thiosulfate which is not adsorbed by activated carbon. 


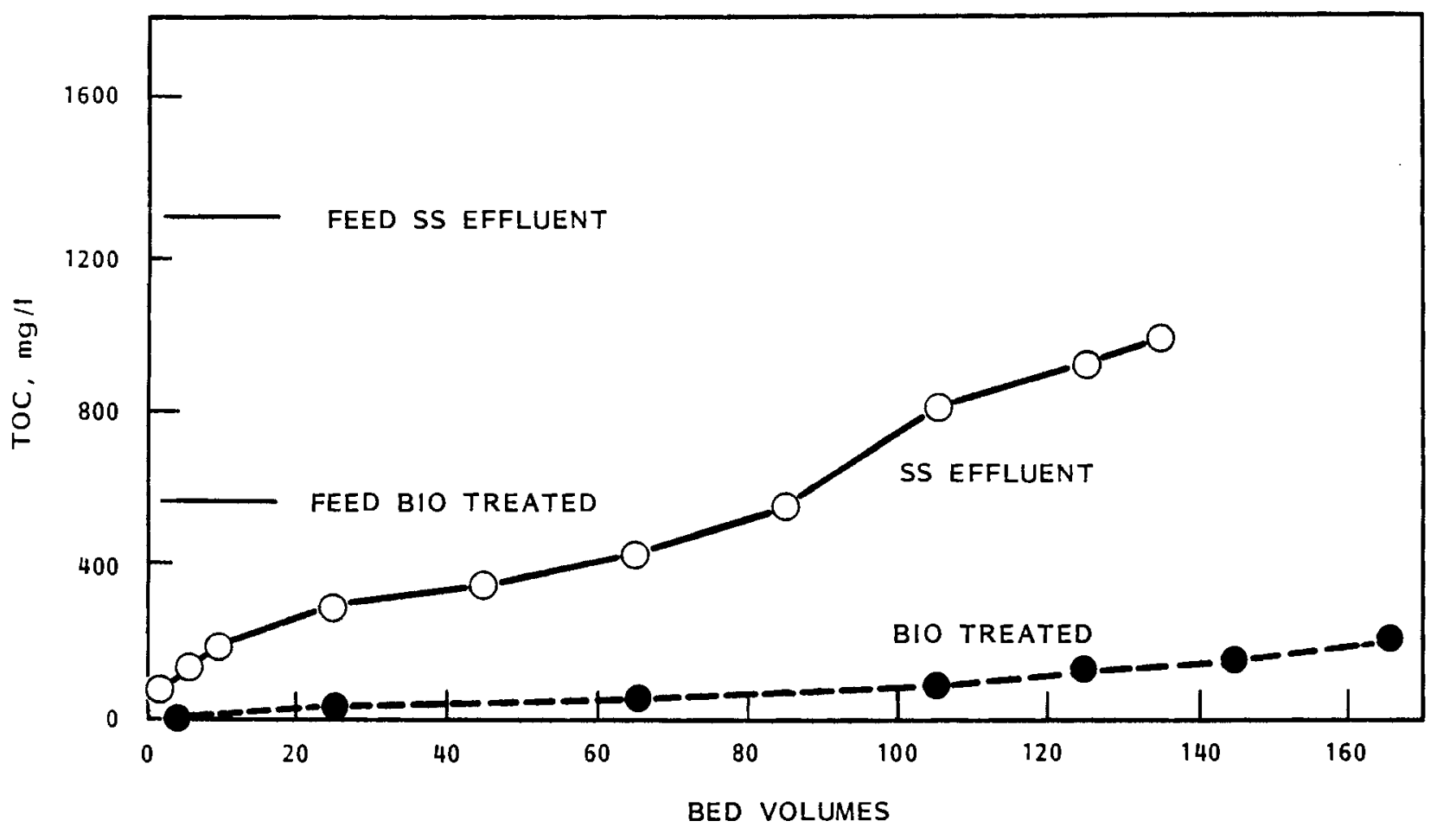

FIGURE 24. Activated Carbon Treatment TOC Removal

\section{ALUM/POLYMER COAGULATION OF B IOTREATED RETORT WATER}

Removal of suspended matter from biologically treated effluent is required to prevent plugging of fixed beds of activated carbon that are generally used to remove refractory organics. A series of batch tests were conducted to evaluate alum/polymer coagulation of activated sludge effluent.

\section{Experimental Methods}

Alum/polymer coagulation tests were performed on activated sludge effluent from the fill-and-draw experiment employing Geokinetics No. 3 retort water with $300 \mathrm{mg} / 1$ PAC addition (see Figure 25). Only effluent from day 40 to day 45 was used to avoid high concentrations of phosphate added as a buffering agent for pH control in the previous feed (Geokinetics No. 4). High concentrations of phosphate interfere with the coagulation of aluminum hydroxide. Because of the small amount of activated sludge effluent available, the coagulation tests were performed with $100 \mathrm{ml}$ of effluent in a 250-ml beaker. Mixing of the contents of the beaker was accomplished with a variable speed stirring machine equipped with $2.5 \times 4.5 \mathrm{~cm}$ paddles. The tests were carried out as follows: 


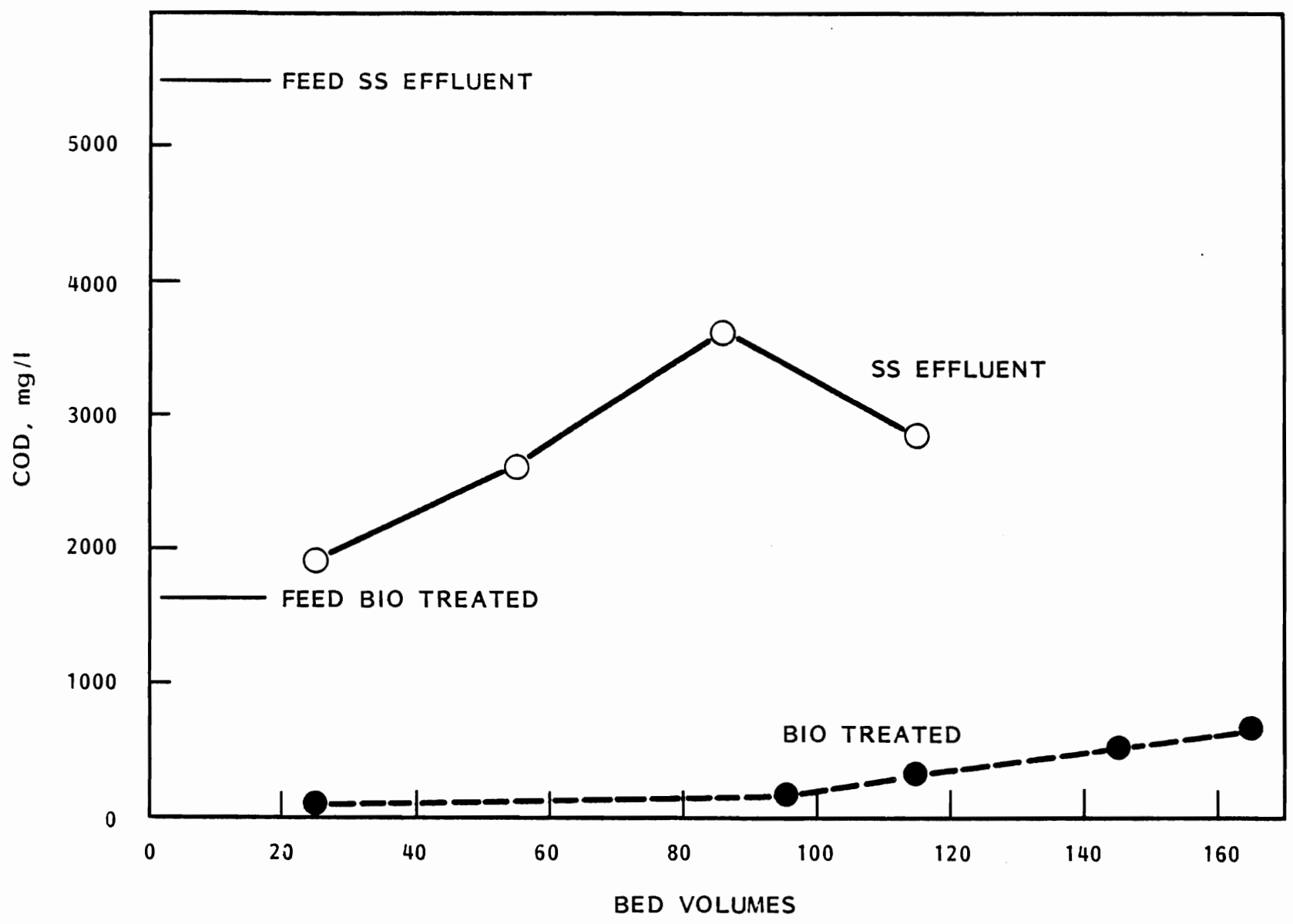

FIGURE 25. Activated Carbon Treatment COD Removal

1) One hundred-ml aliquots of we 11 mixed activated sludge effluent were pipetted into each of five $250 \mathrm{ml}$ beakers.

2) Stirring paddles were lowered into the beakers and the stirring speed was adjusted to 100 RPM.

3) Alum doses varying from $100 \mathrm{mg} / 1$ to $500 \mathrm{mg} / 1$ of $\mathrm{AL}_{2}\left(\mathrm{SO}_{4}\right)_{3} \cdot 18$ $\mathrm{H}_{2} \mathrm{O}$ were added to each of the beakers with a calibrated pipet. A stock solution of $100 \mathrm{~g} / 1$ alum was used.

4) The mixtures were stirred at 100 RPM for 5 min after which $1 \mathrm{mg} / 1$ of polyacrylamide anionic polymer was added to promote flocculation. 
5) Stirring continued at 100 RPM for 1 min after polymer addition then was gradually reduced over a period of $30 \mathrm{sec}$ to $40 \mathrm{RPM}$ and continued at this speed for 15 min.

6) After the 15 min flocculation period, the stirring was stopped, the paddles were removed, and the mixtures were allowed to settle for $30 \mathrm{~min}$.

7) Samples of the supernatant solution were then removed for $\mathrm{pH}$ and nonfiltrable residue determinations.

Results and Discussion

The results of the alum/polymer coagulation tests are presented in Table 21. A rapid settling floc was formed in all of the tests, however there was not a substantial improvement in turbidity and nonfiltrable residue in any of the tests. Turbidity and nonfilterable residue increased at 100 and $200 \mathrm{mg} / 1$ alum treatment which indicates incomplete flocculation. The $300 \mathrm{mg} / 1$ alum addition appeared to be about optimum for this series, therefore a single batch of $400 \mathrm{mls}$ of activated sludge effluent was treated with $300 \mathrm{mg} / 1$ alum and $1 \mathrm{mg} / 1$ of polymer as above, except the $\mathrm{pH}$ was maintained at 6.5 with $\mathrm{NaOH}$ addition. The turbidity of the supernatant liquids at $\mathrm{pH} 6.5$ was somewhat improved at $6.1 \mathrm{NTU}$. Filtration of this supernatant liquid through whatman No. 1 filter paper, which roughly simulates rapid sand filtration, produced a

TABLE 21. Results of Alum/Polymer Coagulation Tests on Biotreated Retort Water

\begin{tabular}{ccc}
$\begin{array}{c}\text { A lum Dosage, } \\
\mathrm{mg} / 1\end{array}$ & $\begin{array}{c}\text { Non-Filterable Residue, } \\
\mathrm{mg} / 1\end{array}$ & $\frac{\mathrm{pH}}{(103 \mathrm{C})}$ \\
\cline { 1 - 2 } 0 & 69 & 6.50 \\
100 & 105 & 6.20 \\
200 & 118 & 5.65 \\
300 & 51 & 5.13 \\
400 & 53 & 4.75 \\
500 & 49 & 4.46
\end{tabular}


filtrate with a turbidity of 4.2 NTU and a nonfilterable residue $\left(103^{\circ} \mathrm{C}\right)$ of $18 \mathrm{mg} / \mathrm{l}$. This filtrate is expected to be sufficiently low in suspended solids to avoid frequent plugging of a granulated carbon bed although occasional backwashing may be necessary.

\section{HEAVY METALS IN TREATED RETORT WATER}

Removal of toxic heavy metals in retort water is desired to render this waste nonhazardous for ultimate disposal. A chemical precipitation method was tested for arsenic removal from effluents produced by the biological and physical-chemical treatment tests were analyzed for heavy metals.

\section{Arsenic Scavenging}

Several jar tests were performed with steam-stripped Geokinetics retort water to evaluate the effectiveness of ferric hydroxide with and without manganese addition for removal of arsenic from steam-stripped retort water. (Arsenate precipitates with ferric hydroxide in a manner similar to that of phosphate.) Prior to completion of the biological treatment study, arsenic was suspected of causing toxicity problems with the activated sludge process. Therefore, an arsenic removal step was inserted between steam stripping and activated sludge treatment. As noted earlier, however, arsenic toxicity was not confirmed in the activated sludge tests. Nevertheless, arsenic removal may be necessary to reduce arsenic concentrations below hazardous waste limitations.

The $j$ ar tests were conducted by the procedure outlined in the previous section on alum/polymer coagulation except that one liter volumes were used. The results of the tests are presented in Tables 22 and 23 . Ferric hydroxide scavenging at $\mathrm{pH} 7.0$ appeared to be near optimum dosage at $100 \mathrm{mg} / 1 \mathrm{Fe}^{+3}$. Reducing the $\mathrm{pH}$ to 6.0 , however, improved both the clarity of the supernatant liquid and the arsenic scavenging. In order to reduce the $\mathrm{pH}$ below 7.0, addition of strong mineral acid $\left(\right.$ e.g., $\left.\mathrm{H}_{2} \mathrm{SO}_{4}\right)$ is required, whereas it is possible to achieve $\mathrm{pH} 7.0$ with $\mathrm{CO}_{2}$ sparging. The unadjusted $\mathrm{pH}$ of the steamstripped geokinetics No. 3 retort water is 10 . 
TABLE 22. Ferric Hydroxide Scavenging of Arsenic Without Manganese Add ition

In itial Arsenic Concentration-- $4.1 \mathrm{mg} / 1$

\begin{tabular}{|c|c|c|c|}
\hline $\begin{array}{c}\mathrm{mg} / 1 \mathrm{Fe}^{+3} \\
\text { Added } \\
\end{array}$ & $\mathrm{pH}$ & Appearance After Sett ling & \begin{tabular}{l}
\multicolumn{1}{r}{ Supernatant } \\
Fluid Arsenic \\
Concentration, $\mathrm{mg} / 1$ \\
\end{tabular} \\
\hline 50 & 7.0 & Poor floc, turbid supernatant fluid & 2.7 \\
\hline 100 & 7.0 & Good floc, turbid supernatant fluid & 1.3 \\
\hline 150 & 7.0 & Good floc, turbid supernatant fluid & 1.1 \\
\hline 100 & 6.0 & Good floc, clear supernatant fluid & 0.94 \\
\hline
\end{tabular}

Test Conditions

1. $\mathrm{Fe}^{+3}$ added as $\mathrm{FeCl}_{3}$ solution $\left(20 \mathrm{~g} / 1 \mathrm{Fe}^{+3}\right)$.

2. $1.0 \mathrm{mg} / 1$. anionic polymer added for flocculation.

3. Arsenic analyzed by graphite furnace atomic absorption.

4. Retort water--steam-stripped geokinetics in situ No. 3.

5. Temperature $--22^{\circ} \mathrm{C}$.

6. $\mathrm{pH}$ adjusted with $\mathrm{H}_{2} \mathrm{SO}_{4}$.

Manganese addition was investigated as a means of improving the scavenging of arsenic because other experimental data on radioactive wastewater treatment indicated improved coagulation with a combination of iron and manganese in comparison to iron alone. As shown in Table 23, addition of either $\mathrm{Mn}^{+2}$ or $\mathrm{Mn}^{+7}$ was effective in achieving a relatively low arsenic concentration although $\mathrm{Mn}^{+7}$ addition was also effective in producing a clear supernatant liquid. Pretreatment of retort water feed to the biological test units for arsenic removal was accomplished by ferric-manganese scavenging. Addition of the manganese as $\mathrm{KMnO}_{4}$ preceeded the addition of ferric chloride. The $\mathrm{KMnO}_{4}$ immediately reacts with reducing agents (e.g., thiosulfate) in the retort water producing a $\mathrm{MnO}_{2}$ precipitate. It is doubtful that oxidation of $\mathrm{As}^{+3}$ to $\mathrm{As}^{+5}$ is involved due to the preponderance of other reducing agents in the retort water. Three consecutive $\mathrm{Fe}^{+3}-\mathrm{Mn}^{+7}$ scavenging reactions were not effective in reducing arsenic below $0.8 \mathrm{mg} / 1$ on a separate test with steamstripped geokinetics in situ No. 3 retort water. 
TABLE 23. Ferric Hydroxide Scavenging of Arsenic with Manganese Addition

In itial Arsenic Concentration-- $4.1 \mathrm{mg} / 1$

\begin{tabular}{l} 
Oxidation \\
State of \\
Mn Added \\
\hline+2 \\
+7 \\
+4
\end{tabular}

Oxidation

State of

$+2$

$+4$

$\begin{array}{lcc}\text { Appearance After Settling } & \begin{array}{c}\text { Supernatant } \\ \text { Fluid Arsenic } \\ \text { Concentration, mg/l }\end{array} \\ { } } & 0.75 \\ \text { Good floc, clear supernatant fluid } & 0.80 \\ \text { Poor floc, turbid supernatant fluid } & 1.2\end{array}$

\section{Test Cond itions}
1. $100 \mathrm{mg} / 1 \mathrm{Fe}^{+3}$ added as $\mathrm{FeCl}_{3}\left(20 \% \mathrm{Fe}^{+3}\right)$.
2. $1.0 \mathrm{mg} / 1$ anionic polymer added for flocculation.
3. Arsenic analyzed by graphite furnace atomic absorption.
4. Retort water--steam-stripped geokinetics in situ No. 3 .
5. Temperature $-22^{\circ} \mathrm{C}$.
6. $\mathrm{pH}$ adjusted with $\mathrm{H}_{2} \mathrm{SO}_{4}$ to 7.0 .
7. For $\mathrm{Mn}^{+2}, 32 \mathrm{mg} / 1$ added as $50 \mathrm{~g} / 1 \mathrm{MnSO}_{4} \mathrm{H}_{2} \mathrm{O}$ solution.
8. For $\mathrm{Mn}^{+7}, 32 \mathrm{mg} / 1$ added as $25 \mathrm{~g} / 1 \mathrm{KMnO}_{4}$ solution.
9. For $\mathrm{Mn}^{+4}, 32 \mathrm{mg} / \mathrm{l}$ added as $17 \mathrm{~g} / 1 \mathrm{MnO}_{2}$ slurry.

Heavy metals and Boron in Treated Effluents

Effluents from various treatment steps in the bench scale studies were analyzed for elemental content by neutron activation and plasma emission spectroscopy. The results of these analyses for heavy metals and boron are presented in Tables 24 and 25 for Utah in situ No. 3 and 4 , respectively. An 80 to $84 \%$ reduction of As was achieved through the $\mathrm{Fe}^{+3}-\mathrm{Mn}^{+7}$ scavenging step, but little or no additional removal was achieved by activated sludge and activated carbon. Effective copper removal was observed particularly by activated carbon. Removals were less than a factor of 2 for B, Co, and Mo. An increase 
TABLE 24. Heavy Metals and Boron in Geokinetics No. 3 Effluents

\begin{tabular}{|c|c|c|c|c|c|c|c|c|c|c|c|c|c|c|}
\hline \multirow[b]{2}{*}{ Eff luent } & \multicolumn{14}{|c|}{ Concentration, $\mathrm{ppm}$} \\
\hline & As & $\underline{B}(a)$ & $\mathrm{Cd}^{(\mathrm{a})}$ & Co & $\mathrm{Cu}^{(\mathrm{a})}$ & $\mathrm{Fe}$ & $M n$ & Mo $(a)$ & $\mathrm{Ni}$ & Sb & $\mathrm{Se}$ & $\mathrm{u}$ & v & $\mathrm{Zn}$ \\
\hline Raw Retort Water & 4.1 & 108 & $<0.01$ & 0.37 & 0.33 & 8 & 0.2 & 8.4 & 0.8 & 0.13 & 0.30 & 0.11 & 0.15 & $<0.3$ \\
\hline Steam Stripper & 4.1 & 110 & $<0.01$ & 0.35 & 0.21 & 5 & 0.2 & 8.2 & 0.8 & 0.13 & 0.34 & 0.11 & $<0.08$ & $<0.3$ \\
\hline $\mathrm{Fe}^{+3}, \mathrm{Mn}^{+7}$ Scavenging & 0.8 & 71 & $<0.01$ & 0.35 & 0.08 & 5 & 2.0 & 7.7 & 1 & 0.08 & 0.26 & 0.09 & $<0.09$ & $<0.3$ \\
\hline Activated Sludge $(\mathrm{b})$ & 0.6 & 107 & $<0.01$ & 0.40 & 0.10 & 5 & 2.0 & 7.1 & 0.7 & 0.08 & 0.18 & 0.04 & $<0.09$ & 0.5 \\
\hline Activated Carbon (c) & 0.6 & 106 & $<0.01$ & 0.30 & $<0.01$ & 5 & 1.3 & 6.8 & 0.7 & 0.08 & 0.14 & 0.04 & $<0.08$ & $<0.3$ \\
\hline
\end{tabular}

(a) Determined by plasma emission spectroscopy. All others were determined by neutron activation.

(b) Alum clarified and filtered activated sludge effluent composite collected between day 40 and day 45 (Figure 19).

(c) Alum clarified and filtered activated sludge effluent composite sample treated with $4 \mathrm{~g} / 1 \mathrm{PAC}$ to give residual TOC of $103 \mathrm{mg} / 1$ (see isotherm in Figure 23).

TABLE 25. Heavy Metals and Boron in Geokinetics No. 4 Effluents

\begin{tabular}{|c|c|c|c|c|c|c|c|c|c|c|c|c|c|c|}
\hline \multirow[b]{2}{*}{ Effluent } & \multicolumn{13}{|c|}{ Concentration, ppm } & \multirow[b]{2}{*}{$\mathrm{Zn}$} \\
\hline & As & $B^{(a)}$ & $\mathrm{Cd}^{(\mathrm{a})}$ & Co & $\mathrm{Cu}^{(\mathrm{a})}$ & $\underline{\mathrm{Fe}}$ & $\mathrm{Mn}$ & $M_{0}(a)$ & $\mathrm{Ni}$ & $\mathrm{Sb}$ & $\mathrm{Se}$ & $\mathrm{U}$ & $v$ & \\
\hline Raw Retort Water & 8.5 & 120 & $<0.01$ & 0.32 & 0.32 & 7 & 0.2 & 5.4 & 0.7 & 0.18 & 0.24 & 0.17 & $<0.08$ & 0.5 \\
\hline $\mathrm{Fe}^{+3}$, Mn Scavenging & 1.4 & 116 & $<0.01$ & 0.27 & 0.04 & 5 & 1.6 & 4.5 & 0.7 & 0.12 & 0.19 & 0.17 & $<0.08$ & $<0.3$ \\
\hline Activated Carbon (b) & 1.0 & 77 & $<0.01$ & 0.21 & $<0.01$ & 5 & 0.2 & 3.8 & 0.8 & 0.07 & 0.08 & 0.06 & $<0.09$ & $<0.3$ \\
\hline
\end{tabular}

(a) Determined by plasma emission spectroscopy. All others were determined by neutron activation.

(b) Effluent from activated carbon column at 165 bed volumes of previously biotreated and clarified effluent (see Figure 24). 
in Mn was observed following the $\mathrm{Fe}^{+3}-\mathrm{Mn}^{+7}$ scavenging step, which is believed due to incomplete precipitation of the Mn. The remaining metals, $\mathrm{Cd}$, $\mathrm{Fe}, \mathrm{Ni}, \mathrm{V}$, and $\mathrm{Zn}$, are either below or too near detection limits to determine removal levels.

\section{PRELIMINARY COST ESTIMATES}

Preliminary cost estimates were made to determine the economic feasibility of physical-chemical and biological treatment of in situ retort water. Est imated Costs of Physical-Chemical and Biological Treatment

Cost estimates based on bench scale studies may be subject to considerable error. These preliminary estimates, however, are often useful in the initial decision process to select or reject a specific process or process train for further study. For example, a process may be too costly compared to alternatives under the most optimistic assumptions. The cost estimates reported herein was developed for a wastewater reuse objective where the finished effluent is used for cooling purposes (e.g., recirculated through a cooling tower). The effluent has not been demineralized since it may be possible to concentrate it several fold in the cooling tower without scaling problems. Concentration factors of 20 or more have been demonstrated with a falling film pilot plant evaporator without serious scaling problems. Use of a highly saline water in a cooling system will, however, require the use of corrosion resistant material. The presence of a small ammonia residual (e.g., 100 to $200 \mathrm{mg} / 1$ ) will also preclude the use of copper or copper alloys. The major objectives of the treatment steps are: 1) remove biodegradable organics which may cause fouling of the cooling system; and 2) reduce the odor of the retort water to a level that will avoid a nuisance condition downwind from the cooling tower. Suspended matter and ammonia are removed from the raw water to permit biological treatment and biological solids are removed by coagulation and filtration to avoid plugging of the activated carbon columns.

Preliminary cost estimates for the five processing steps used to produce an effluent suitable for cooling water are given in Table 26 . These estimates 
TABLE 26. Preliminary Cost Estimates for Retort Water Treatment

\begin{tabular}{|c|c|}
\hline Processing Step & Cost Range $\$ / 1000$ gal \\
\hline 1. Separation of suspended matter & $0.07-0.20$ \\
\hline 2. Ammonia stripping & $4.82-12.13$ \\
\hline 3. Activated sludge & $3.09-5.65$ \\
\hline 4. Coagulation-filtration & $0.55-0.64$ \\
\hline 5. Activated carbon adsorption & $2.25-6.13$ \\
\hline TOTAL & $10.78-24.75$ \\
\hline
\end{tabular}

are projected for retort water which is similar to that produced by nearsurface horizontal in situ retorting near Vernal, Utah. A range of costs are given for each step. The low cost assumes more optimistic assumptions than the high cost. For example, the low cost est imate for activated sludge treatment assumes one-day detection time in the aeration basin, whereas the high cost est imate assumes a two-day detection time. The methods and assumptions used for preparing the cost estimates are given in the appendix.

The total cost for the five processing steps ranges from $\$ 10.78$ to $\$ 24.75$ per thousand gallons of water treated. Ultimate disposal costs for the cooling tower blowdown are not included and may be substantial if this waste is class ified as hazardous due to residual toxicant concentrations (e.g., As and $\mathrm{Se})$. The above wastewater treatment costs will add from $\$ 0.45$ to $\$ 1.04 /$ barre 1 of $0 \mathrm{il}$ produced at a 1:1 volume ratio of retort water to $0 \mathrm{il}$. The major cost factors in these estimates are: 1) steam consumption for ammonia stripping; 2) acid addition for $\mathrm{pH}$ control and aeration time for activated sludge treatment; and 3) activated carbon exhaustion rate. Cost reductions are possible through the use of alternative methods; however, these would require further study. Acid consumption, for example, in activated sludge treatment may be reduced but not eliminated by adding waste flue gas with $\mathrm{CO}_{2}$ to the air injected in the aeration basins. 


\section{Alternative Treatment Processes}

In view of the high costs estimated for conventional physical-chemical and biological treatment, consideration should be given to other potentially lower cost processes. Possible alternatives include the following:

- ultrafiltration

- reverse osmosis

- evaporation

- solvent extraction

- wet air oxidation.

Ultrafiltration and solvent extraction may be considered as pretreatment steps to reduce the organic loading to subsequent biological processing. Biological processing would remain at a substantial cost level in spite of this pretreatment due to the presence of residual organics thiosulfate and thiocyanate. Over one third of the minimum cost estimate for biological treatment is due to mineral acid addition needed to sustain good biological oxidation. Armonia removal would also be required.

Reverse osmos is is attractive as a treatment process for some types of wastewater because of its ability to remove both organic and inorganic pollutants from wastewaters. The typically high dissolved mineral content in situ retort presents a rather severe test for this process because high levels of water recovery are not possible. For example, freshwater recovery from seawater by reverse osmosis is in the range of 20 to $25 \%$. It is doubtful that practical recovery of freshwater from a saline retort water would exceed $50 \%$. Treatment and disposal costs for the reject brine would be quite high. The unstable nature of the dissolved organics in retort water would be expected to cause fouling problems with the reverse osmosis membranes.

Evaporation shows considerable potential for high water recovery and is currently being investigated as a treatment process for retort water. Anticipated costs for evaporation are approximately $\$ 10 / 1000$ gal, but additional treatment may be necessary to remove organic matter from the condensate. 


\section{REFERENCES}

American Petroleum Institute. 1963. Manual on Disposal of Refinery Wastes, volume 1.

Annessen, R. J. and G. D. Gould. 1971. "Sour Water Processing Turns Problem Into Payout." Chemical Engineering, pp. 67-69.

Ashmore, A. G., J. R. Catchpole and R. L. Cooper. 1967. "The Biological Treatment of Carbonization Effluents - I. Investigation into Treatment by the Activated Sludge Process." Water Research. 1:605.

Baum, J. S. and P. V. Prather. 1971. "0ily Wastewater Treatment." Industrial 0ily Waste Control, American Petroleum Institute and American Society of Lubrication Engineers.

Beychok, M. R. 1967. "Aqueous Wastes from Petroleum and Petrochemical Plants." John Wiley and Sons, New York.

Culp, G. L. and R. L. Culp. 1971. Advanced Wastewater Treatment. Van Nostrand Reinhold Co., New York.

Farrier, D. S., L. W. Harrington, and R. E. Poulson. 1978. "Integrated Compliance and Control Technology Research Activities for in situ Fossil Fue1 Processing Experiments." In Proceedings of U.S. Department of Energy Environmental Control Symposium, Washington, DC, November 28-30, 1978.

Finneran and Whelche1. 1970. "Recovery and Reuse of Aqueous Effluent from a Modern Ammonia Plant." Proceedings Ind. Process Design Workshop, March 31 to February 2, 1970, pp. 109-113, AIChE, San Francisco, California.

Fox, J. P., D. S. Farrier, and R. E. Poulson. 1978. "Chemical Characterization and Analytical Considerations for an in situ 0il Shale Process Water." U.S. Department of Energy, Laramie Energy Technology Center Report of Investigations, Laramie, Wyoming.

Grieves, C. G., L. W. Crame, D. G. Venardos, and W. Ying. 1978. "Powdered Carbon Enhancement Versus Granular Carbon Adsorption for 0il Refinery BATEA Wastewater Treatment." Paper presented at the 51 st Annual Conference of the Water Poll. Control Fed., October 3, 1978, Anaheim, Californid.

Gurnham, C. F. 1965. Industrial Wastewater Control. Academic Press, pp. 224-228, New York, NY.

Harding, B. L., K. D. Linstedt, and E. R. Bennett. 1979. "Removal of Ammonia and Alkalinity from $0 i l$ Shale Wastewaters," Laramie Energy Technology Center Report LETC-3096-1. 
Hart, J. A. 1970a. "Air Flotation Treatment and Reuse of Refinery Wastewater." Proceedings 25th Industrial Waste Conference, pp. 406-413, Purdue University, Lafayette, Indiana.

Hart, J. S. 1970b. "An Improving Wastewater Quality." Water and Sewage Works. pp. 1W20-1W26.

Hubbard, A. B. 1971. "Method for Reclaiming Wastewater from 0 il Shale Processing." Paper presented at Am. Chem. Soc. Div. of Fuel Chem., Preprints, 15(1):21-24, March 29-Apri1 2, 1971.

ICI America. 1972. "Powdered Hydrodarco Activated Carbons Improved Activated Sludge Treatment." PC-4.

Klett, R. J. 1972. "Treat Sour Water for Profit." Hydrocarbon Processing, pp. 97-99.

Kostenbader, P. D. and J. W. Flecksteiner. "Biological Oxidation of Coke Plant Weak Ammonia Liquor." J. Water Pol. Control Fed. 41(2) Part 1.

Long, A., Jr., N. W. Merriam, and C. J. Mones. 1977. "Evaluation of Rock Springs Site 9 in situ $0 i 1$ Shale Retorting Experiment." In Proceedings of 10th 0il Shale Symposium, p. 120, Colorado School of Mines, Golden, Colorado.

Linstedt, K. D., E. R. Bennett and B. Harding. 1976. "Characterization and Treatment of Retort Water from in situ $0 i 1$ Shale Processing. " Final Report PL 61683 for Laramie Research Center, U.S. Energy Research and Development Administration, Laramie, Wyoming.

Mavrovic, I. 1974. "Recovery of Nitrogen Compounds from Effluents in Area and Ammonia Plants." Proceedings Workshop on Industrial Process Design for Pollution Control, October 15-17, 1974, Vol 7, pp. 1-5, New Orleans, Louisiana.

Melin, G. A., J. L. Niedzwiecki, and A. M. Goldstein. 1975. "Optimum Design of Sour Water Strippers." Chem. Eng. Progress. 71:78.

Mercer, B. W., L. L. Ames, Jr., C. J. Touhill, W. J. Van Slyke and R. B. Dean. 1970. "Ammonia Removal from Secondary Effluents by Selective Ion Exchange." J. Water Pollution Control Fed., 42, R-95-107, Part 2.

Mercer, B. W., A. C. Campbe11, and W. Wakamiya. 1979. Evaluation of Land Disposal and Underground Injection of Shale $0 i 1$ Wastewaters. PNL-2596, Pacific Northwest Laboratory, Richland, Washington.

Metcalf and Eddy, Inc. 1972. "Wastewater Engineering, Collection, Treatment and Disposal." McGraw Hill Book Co., New York, p. 718.

Ossio, E. A., J. P. Fox, J. F. Thomas and R. E. Poulson. 1978. "Anaerobic Fermentation of Simulated in situ 0 il Shale Retort Water." A.C.S. Div. of Fuel Chemistry Preprints 23:2, pp. 202-213. 
Robertaccio, F. L., et al. 1972. "Treatment of Organic Chemicals Plant Wastewater with the DuPoint PACT Process." Paper presented at AIChE National Meeting, February 20-23, 1972, Dallas, Texas.

Rodriguez, D. G. 1974. "Sour Water Stripper: Its Design and Application." Water-1973 Am. Inst. Chem. Eng. Symposium Series 173. 70:667-670.

Shangra, T. 1979. "Master's Thesis. University of Colorado, Boulder, Colorado.

Shreve, R. N. 1967. "Chemical Process Industries." Third Edition, pp. 70-76. McGraw-Hil1 Book Co., New York.

Standard Methods for the Examination of Water and Wastewater. 1975. 14th Edition, U.S. Public Health Assoc., Washington, D.C.

Suhr, L. G. and L. Kepple. 1975. "AWT Plant Gets Tough with Ammonia." Water and Wastes Eng., pp. 16-30.

Thackston, E. L. 1972. "Flotation." Process Design in Water Quality Engineering: New Concepts and Developments. E. L. Thackston and W. W. Eckenfelder, Editors, pp. 34-51, Jenkens Publishing Co., Aust in and New York.

Van Krevelin, D. W., P. J. Hoffijzer, and F. J. Huntjens. 1949. "Compositions and Vapor Pressures of Aqueous Solutions of Ammonia, Carbon Dioxide, and Hydrogen Sulfide." Record Trav. Chim. Pays. Bas. 68:191.

Weber, W. J., Jr. 1972. Physiochemical Process for Water Qual ity Control. John Wiley and Sons, Inc., New York.

Whitcombe, J. A. and R. G. Vauter. 1976. "The TOSCO-II 0il Sha le Process." Science and Technlogy of $0 i l$ Shale, T.F. Yen, Ed. Ann Arbor Science Publishers, Ann Arbor, Michigan.

U.S. Environmental Protection Agency. 1974. "Petroleum Refining: Point Source Category," EPA-44011-74-014a, Washington, D.C.

University of Texas Press. 1970. Advances in Water Quality Improvement, E. Gloyna and W. W. Eckenfelder, Jr., Editors. University of Texas, Aust in, Texas.

Wong, A. L. and B. W. Mercer. 1979. "Contribution of Thiosulf ate to COD and BOD in 0 il Shale Process Wastewater." In Proceedings of American Society for Testing and Materials Symposium on Analysis of Water Associated with Alternate Fuel Production, Pittsburgh, Pennsylvania, June 4 and 5, 1979. 
APPENDIX

CAPITAL AND OPERATING COST ESTIMATES FOR PHYSICAL-CHEMICAL AND BIOLOGICAL TREATMENT OF SHALE OIL RETORT WATER 
APPENDIX

CAPITAL AND OPERATING COST ESTIMATES FOR PHYSICAL-CHEMICAL AND BIOLOGICAL TREATMENT OF SHALE OIL RETORT WATER

\section{GENERAL COST ELEMENTS}

1) Capital recovery was based on $12.5 \%$ interest over a 10-yr period. Capital recovery factor $=0.181$.

2) Taxes and insurance were estimated as $2 \%$ of capital investment.

3) Electric power costs were $3 \phi / \mathrm{kwh}$.

4) Labor costs were $\$ 10 / \mathrm{hr}$.

5) Costs are for January 1980.

A. Cost Estimates for Removal of Suspended Matter

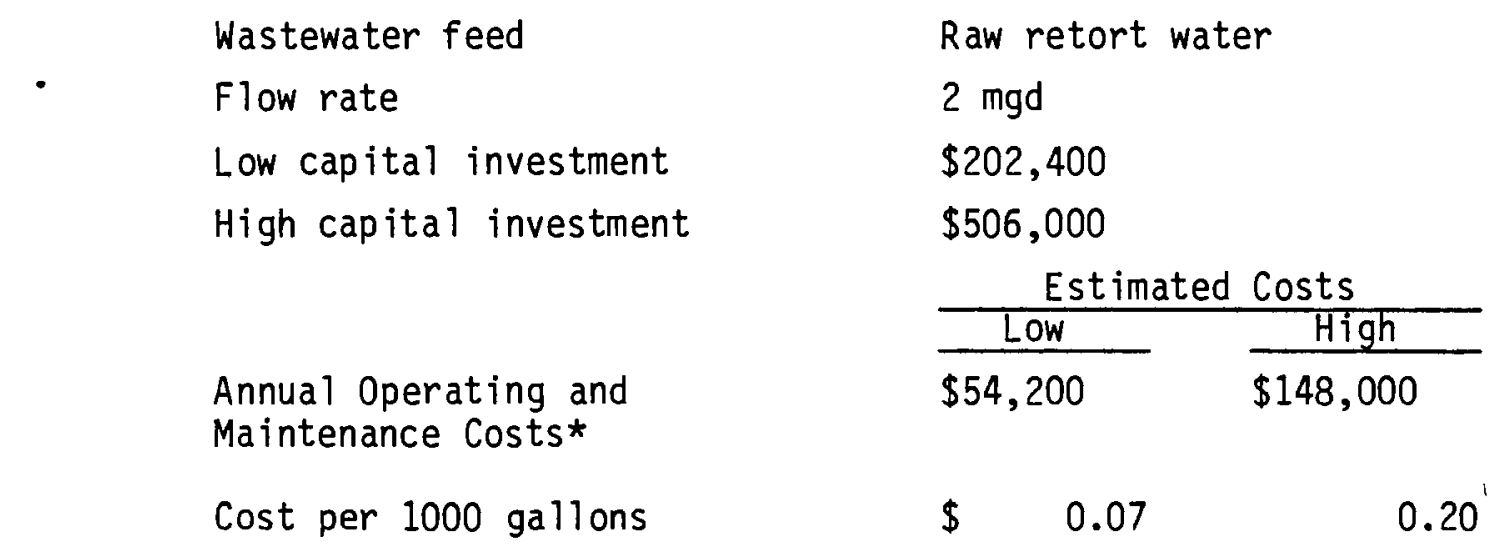

* Includes labor, power, materials, depreciation, insurance, and taxes.

Design Basis

1) The low cost estimate is based on gravity sedimentation using a circular primary clarifier only.

2) The high cost estimate includes both a primary clarifier and a dissolved air flotation unit. 


\section{Computations}

1) Data source--Reference 1 .

2) Costs were updated for dissolved air flotation by increasing reported 0\&M costs for 1976 by $25 \%$.

B. Cost Estimates for Steam Stripping

\begin{tabular}{|c|c|c|}
\hline $\begin{array}{l}\text { Wastewater feed } \\
\text { Flow rate } \\
\text { Capital investment }\end{array}$ & \multicolumn{2}{|c|}{$\begin{array}{l}\text { Clarified raw retort water } \\
2 \mathrm{mgd}\end{array}$} \\
\hline Annual Costs & Estimated Costs & High \\
\hline Operating labor & 22,000 & 22,000 \\
\hline Electric power & 38,000 & 38,000 \\
\hline Steam & $2,400,000$ & $7,150,000$ \\
\hline Cooling water & 292,000 & 876,000 \\
\hline Maintenance & 55,000 & 55,000 \\
\hline Capital recovery & 641,000 & 641,000 \\
\hline Taxes and insurance & 71,000 & 71,000 \\
\hline Total annual cost & $\$ 3,519,000$ & $\$ 8,853,000$ \\
\hline Cost per 1000 gallons & 4.82 & \\
\hline
\end{tabular}

Design Basis

1) Low estimate assumed at 670 1b of steam used per 1000 gal of wastewater treated.

2) High estimate assumes 2000 lb of steam used per 1000 gal of wastewater treated.

3) Ammonia removal is $90 \%$.

Computation

1) Data source--Reference 4 .

2) Cooling water useage is $6 \mathrm{gal}$ per $1 \mathrm{~b}$ of steam used. 
C. Cost Estimates for Activated Sludge Treatment

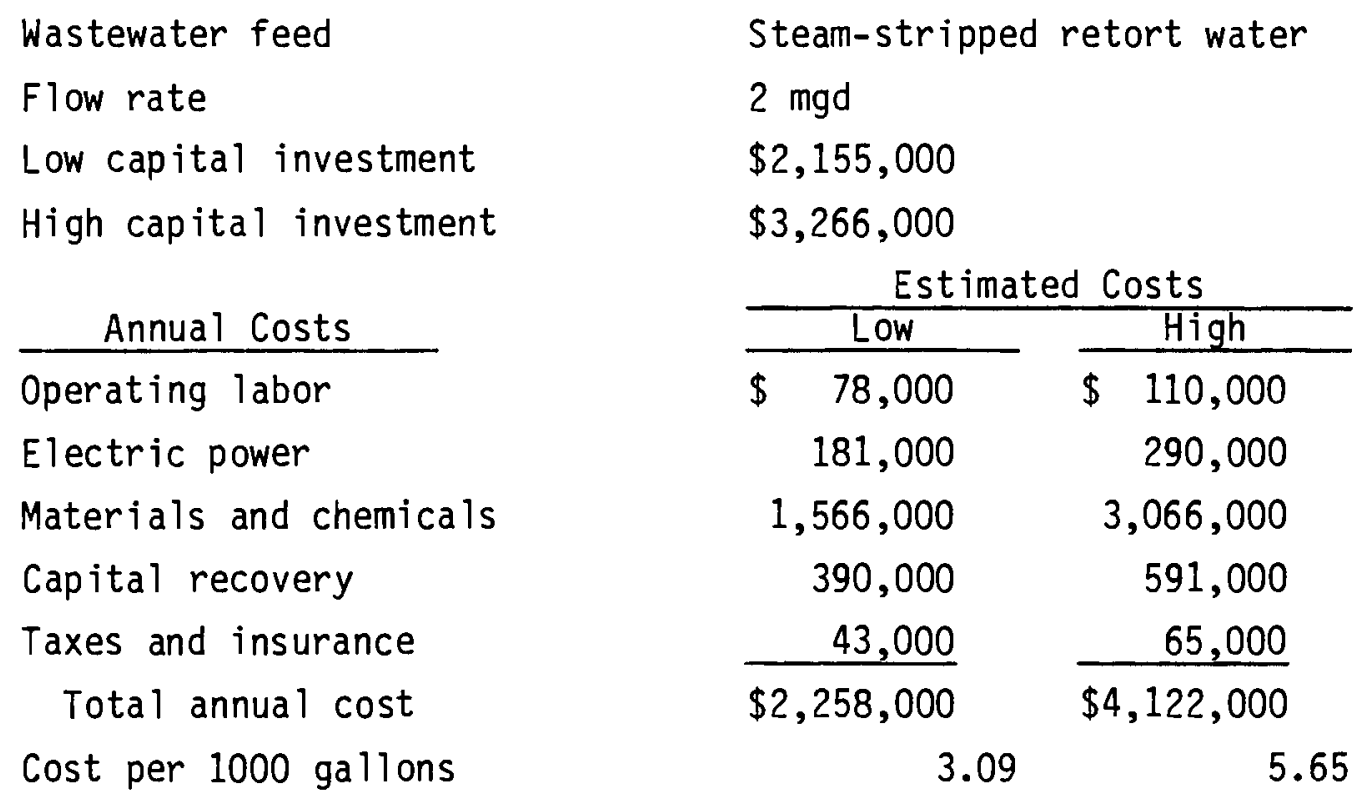

Design Basis

1) Low cost estimate is based on one-day detention time in the aeration basin--a feed COD of $3910 \mathrm{mg} / 1$ and an alkalinity of $7250 \mathrm{mg} / 1$ as $\mathrm{CaCO}_{3}$.

2) High cost estimate is based on a two-day detention time in the aeration basin--a feed $\operatorname{COD}$ of $5900 \mathrm{mg} / 1$ and an alkalinity of $10,750 \mathrm{mg} / 1$ as $\mathrm{CaCO}_{3}$.

3) Oxidation of $65 \%$ of the COD was achieved.

4) Aeration requirement is 1.1 lb of $\mathrm{O}_{2}$ per lb of COD removed.

5) Sludge return capacity was $50 \%$ of wastewater flow while the average sludge return flow was $15 \%$.

6) Mixed liquor was maintained at $\mathrm{pH} 7$ by neutralizing $90 \%$ of the total alkalinity with sulfuric acid which costs $4 \$ / l b$.

7) The high cost estimate includes addition of $300 \mathrm{mg} / 1$ powdered activated carbon. 
Computation

1) Data source for biological treatment--Reference 3.

2) Data source for equipment cost for acid addition--Reference 2.

3) Data source for equipment and labor costs for PAC addition--Reference 1.

4) Sulfuric acid cost $=4 \$ / 1 b$.

5) $\mathrm{PAC}$ cost $=40 \$ / 1 \mathrm{~b}$.

D. Costs for Chemical Coagulation, Sedimentation, and Filtration

Wastewater feed

Flow rate

Capital investment

Annual Costs

Labor

Electric power

Materials and chemicals

Capital recovery

Taxes and insurance

Total annual cost

Cost per 1000 gallons
Activated sludge effluent $2 \mathrm{mgd}$

$\$ 1,076,000$

\begin{tabular}{|c|c|}
\hline Estimat & d Costs \\
\hline Low & High \\
\hline$\$ 47,000$ & $\$ 47,000$ \\
\hline 63,000 & 63,000 \\
\hline 78,000 & 142,000 \\
\hline 195,000 & 195,000 \\
\hline 22,000 & 22,000 \\
\hline$\$ 405,000$ & $\$ 469,000$ \\
\hline 0.55 & 0 \\
\hline
\end{tabular}

Design Basis

1) Low cost estimate based on alum dosage of $200 \mathrm{mg} / \mathrm{l}$.

2) High cost estimate based on alum dosage of $400 \mathrm{mg} / 1$.

3) Polymer dosage is $1 \mathrm{mg} / 1$.

4) Facilities include a circular secondary clarifier, equipment for storage and addition of alum and polymer, and a dual media filter. Computation

1) Source of data--Reference 1. 
2) Capital cost is based on addition of $400 \mathrm{mg} / 1$ alum.

E. Cost Estimates for Granular Activated Carbon Treatment

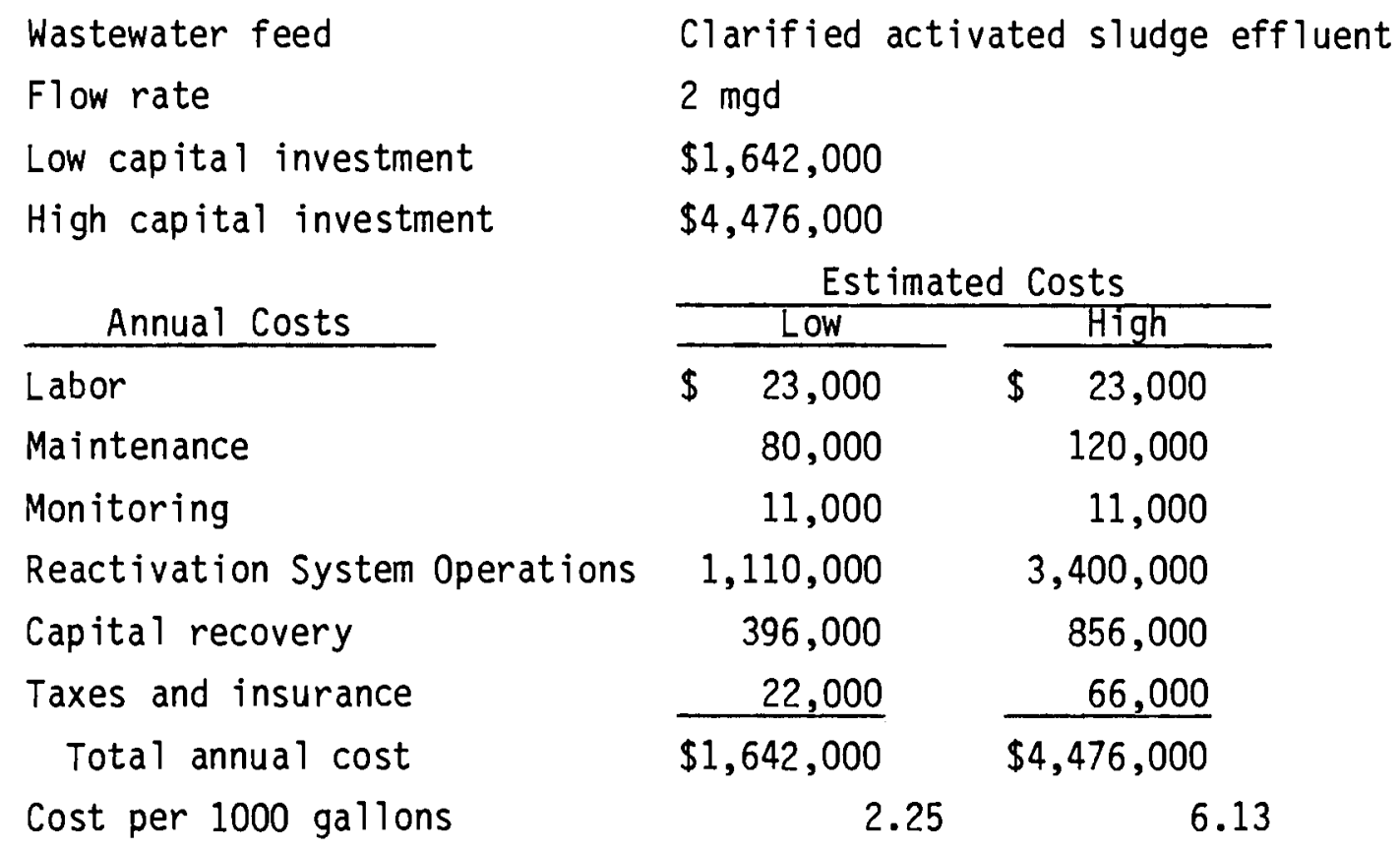

Design Basis

1) Carbon contact time of $30 \mathrm{~min}$.

2) On-site regeneration.

3) Low cost estimate is based on minimum amount of carbon to achieve odor control $(1.53 \mathrm{~g} / 1)$.

4) High cost estimate is based on carbon addition $(4.9 \mathrm{~g} / 1)$ used in batch contact to achieve odor control.

Computation

1) Data source--Reference 5 .

2) Costs updated from 1978 to 1980 by $14 \%$ addition.

\section{REFERENCES}

1. EPA. 1978. Innovative and Alternative Techno logy Assessment Manual. Report No. EPA-430-78-009. 
2. Gumerman, R. C., R. L. Culp and S. P. Hanson. 1979. Estimating Water Treatment Costs, Volume 2. Report No. EPA-600/2-79-162b.

3. Benjes, H. H., Jr. 1979. Handbook of Biological Wastewater Treatment. Garl and STPM Press, New York.

4. Berkawitz, et al. 1976. Physical, Chemical, and Biological Waste Treatment Techniques for Industrial Wastes. NTIS Report No. PB-275 287.

5. Zanitch, R. H., and M. H. Stenzel. 1978. "Economics of Granular Activated Carbon Water and Wastewater Treatment Systems." Carbon Adsorption Handbook, P. N. Cheremisinoff and F. Ellerbusch, ed., Ann Arbor Science, Ann Arbor, Michigan. 


\section{$\underline{\text { DISTRIBUTION }}$}

No. of

Copies

OFFSITE

27 DOE Technical Information Center

5 Charles Grua

U.S. Department of Energy

EV-142, D-232, GTN

Washington, D.C. 20545

Will ard Chappell

The $0 i 1$ Shale Task Force

University of Colorado at Denver

1100 14th Street, Box 136

Denver, Colorado 80202

Ralph Frank lin

U.S. Department of Energy

EV-34, GTN

Mailstop E201

Washington, D.C. 20545

R. N. Heistand

Paraho Development Coporation

Anvil Points, Box A

Rifle, Colorado 81650

Art Hartstein

U.S. Department of Energy

D-107, FE-30, GTN

Washington, D.C. 20545

J. C. Knepper

Rio Blanco Oil Sha le Company

Dayton Commons

9725 Eâst Hampden Avenue

Denver, CO 80231
No. of

Copies

M. A. Lekas

Geokinetics, Incorporated

Suite D-2

391 Chipeta Way

Salt Lake City, Utah 84108

K. D. Linstedt

University of Colorado

Boulder, CO 80309

R. E. Poulson

Laramie Energy Research Center

Department of Energy

P.0. Box 3395, University Station

Laramie, WY 82071

T. J. Powers

U.S. Environmental Protection Agency

555 Ridge Avenue

Cincinnati, $\mathrm{OH} 45268$
A. J. Rothman
Lawrence Livermore Laboratory
P.0. Box 808, M.S. L-207
Livermore, CA 94550
R. Thomason
Occidental 0 il Shale Inc.
P.0. Box 2687
Grand Junction, CO 81502
G. Rowe
Exxon Research and Engineering Company
P.0. Box 101
Florham Park, NJ 07932 
No. of

Copies

DOE Richland Operations

H. E. Ranson

70 Pacific Northwest Laboratory

W. J. Bair

A. C. Campbel1

D. B. Cear lock

G. W. Dawson

J. S. Fruchter

T. R. Garland

S. Marks

B. W. Mercer (50)

R. E. Wildung

Publishing Coordination (BE) (2)

Technical Information (5)

Geosciences Research and

Engineering Library (5) 